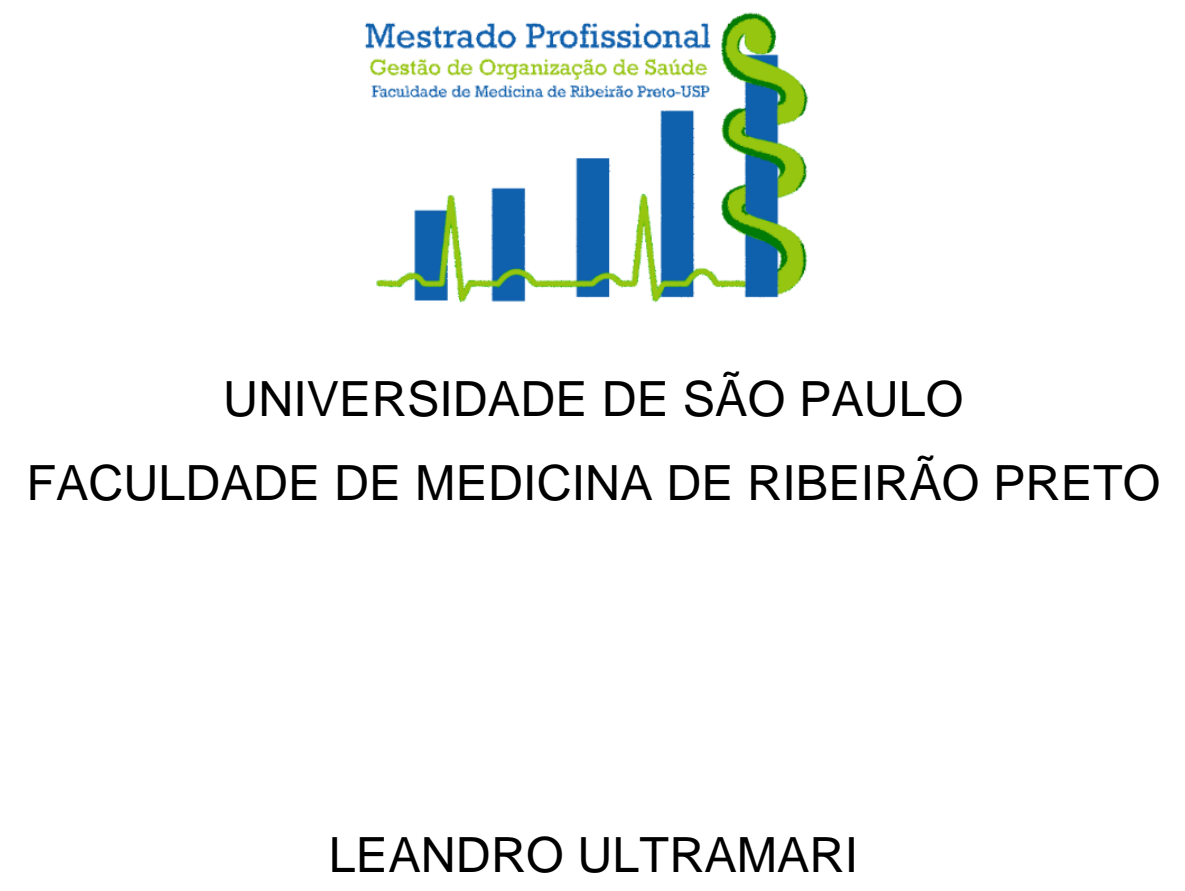

Avaliação da estratégia de Gestão de Pessoas frente à caracterização dos pedidos de reclamação trabalhista de uma Organização Social

Ribeirão Preto

2020 


\title{
Avaliação da estratégia de Gestão de Pessoas frente à caracterização dos pedidos de reclamação trabalhista de uma Organização Social
}

\begin{abstract}
Dissertação apresentada ao Programa Mestrado Profissional em Gestão de Organizações de Saúde - Faculdade de Medicina de Ribeirão Preto como parte dos requisitos para a obtenção do Título de Mestre.
\end{abstract}

Orientador: Prof. Dr. Tales Rubens de Nadai

Ribeirão Preto 
Autorizo a reprodução e divulgação total ou parcial deste trabalho, por qualquer meio convencional ou eletrônico, para fins de estudo e pesquisa, desde que citada a fonte.

Leandro, Ultramari

Avaliação da estratégia de Gestão de Pessoas frente à caracterização dos pedidos de reclamação trabalhista de uma Organização Social, 2020.

$99 \mathrm{p}$.

Dissertação de Mestrado, apresentada à Faculdade de Medicina de Ribeirão Preto/USP.

Orientador: Tales Rubens de, Nadai

1. Reclamações trabalhistas. 2. Gestão de pessoas. 3. Relações de emprego. 4. Administração. 
Nome: Leandro Ultramari

Título: Avaliação da estratégia de Gestão de Pessoas frente à caracterização dos pedidos de reclamação trabalhista de uma Organização Social

Dissertação apresentada ao Programa Mestrado Profissional em Gestão de Organizações de Saúde - Faculdade de Medicina de Ribeirão Preto como parte dos requisitos para a obtenção do Título de Mestre.

Aprovado em:

Banca Examinadora

Prof (a). Dr (a).

Instituição Julgamento

Assinatura

Prof (a). Dr (a).

Instituição Julgamento

Assinatura

Prof (a). Dr (a).

Instituição Julgamento

Assinatura 


\section{AGRADECIMENTO}

Confesso que costumo permanecer tranquilo quando o tema é agradecer, em dado momento em vida percebi que nada é alcançado sozinho e que as pessoas a nossa volta são o único meio de transformar a realidade que almejamos. Infelizmente, ainda passamos muito tempo calculando variáveis como tempo e tantas outras mais de aspectos materiais. Por isso, busco demonstrar a todo custo a admiração que me desperta as pessoas que meu destino me ofereceu. Além disso, para mim, o significado de qualquer frase que contemple a palavra destino, carrega consigo uma percepção aquém da costumeira e apesar de me considerar distante de qualquer religião, seu valor para mim remete sempre ao sentido de que algo "maior" colocou aquilo em minha vida. Dessa forma, sempre culpo o "destino" por tudo que cruza meu caminho.

Portanto, inicialmente gostaria de agradecer minha família, com ela foi possível ter a oportunidade de aprender e praticar valores, os quais não julgo os melhores de que nenhuma outra família poderia ser capaz de prover. Porém, tais ensinamentos me trouxeram na atualidade uma segurança emocional de grande valia e, consequentemente, conseguir conviver e exercer minha profissão da melhor forma.

À minha esposa que tem suportado e apoiado minha motivação em continuar adquirindo conhecimento e a me desenvolver tanto em aspectos profissionais, quanto pessoais.

Ao Prof. Dr. Tales Rubens de Nadai por sempre ter acreditado em meu potencial desde a nossa primeira conversa. Já demonstrei o quanto sua personalidade e história são fontes de inspiração.

Aos meus colegas de trabalhos que de alguma forma ajudaram a dar vida ao projeto. Em especial o Sr. Mário Bezerra de Menezes, pelos momentos em que me motivou, questionou e auxiliou na viabilização de todo o projeto.

A todos os professores e demais colegas de profissão que passaram pela minha vida até aqui. Em especial o Prof. Dr. Paulo Eduardo Benzoni que de maneira imperceptível me influenciou para que chegasse onde estou.

Por fim, gostaria de agradecer ao apoio da Coordenação de Aperfeiçoamento de Pessoal de Nível Superior - Brasil (CAPES). 


\section{RESUMO}

ULTRAMARI, Leandro. Avaliação da estratégia de Gestão de Pessoas frente à caracterização dos pedidos de reclamação trabalhista de uma Organização Social. 2020. Dissertação (Mestrado Profissional em Gestão de Organizações de Saúde) - Faculdade de Medicina de Ribeirão Preto, Universidade de São Paulo, Ribeirão Preto, 2020.

Introdução: o número de ajuizamento de ações trabalhistas no Brasil sobe a cada ano. O fenômeno impacta diretamente na eficiência organizacional e, os processos da Gestão de Pessoas (GP) têm se mostrado uma opção de intervenção neste contexto. Objetivo: identificar quais processos da GP tem maior relevância nas reclamações trabalhistas. Método: estudo exploratório e retrospectivo, a partir de uma amostra de todas as reclamações trabalhistas ajuizadas contra uma Organização Social da área da saúde de 08/2010 até 12/2018, caracterizadas e posteriormente analisadas de forma quantitativa e qualitativa. Resultados: foi constatado que 0 número de reclamações trabalhistas aumentou com o passar dos anos, com redução no ano de 2018, após a aprovação da Reforma Trabalhista pela Lei oㅜ 13.467 e que os processos da GP que apresentaram maior relevância nas ações foram: recompensar $(47 \%)$ e manter (37\%) pessoas. Conclusões: a legislação trabalhista intervém diretamente nas relações de trabalho de maneira arbitrária e impositiva, ocasionando a defesa de causas muitas vezes já ultrapassadas pela realidade atual da sociedade e das organizações. Isso pode explicar o volume de pedidos ligados aos processos de recompensar e manter da GP. O estudo também reconheceu a possível diminuição no ajuizamento de ações em razão da reforma trabalhista e a influência do agrupamento dos pedidos em ações advindas de um mesmo escritório na amostra analisada.

Palavras-chaves: reclamações trabalhistas; gestão de pessoas; relações de emprego; administração. 


\begin{abstract}
ULTRAMARI, Leandro. Evaluation of the people management strategy in view of the characterization of requests for labor recovery from a social organization. 2020. Dissertation (Master in Management of Health Organizations) - Medical School of Ribeirão Preto, University of São Paulo, Ribeirão Preto, 2020.
\end{abstract}

Introduction: the number of employee grievances in Brazil increases every year. This phenomenon has a direct impact on organizational efficiency and the processes of People Management (PM) have direct access to act in that context. Objective: identify what PM processes have greater relevance in employee grievances. Method: an exploratory and retrospective study, with a sample of all labor claims against a social organization from $08 / 2010$ to $12 / 2018$, characterized and later analyzed quantitatively and qualitatively. Results: it was observed that the number of labor claims increased with the passage of the years, with reduction in the year 2018 after the approval of labor reform and the processes of PM that present greater relevance in the organization are: reward (47\%) and retain (37\%) people. Conclusions: labor legislation intervenes directly in labor relations in an arbitrary and enforceable way, leading to the defense of causes that are often outdated by the current reality of our society and organizations. Which influences in the volume of orders linked to PM reward and retain processes. The study also recognized the possible decrease in employee grievances due to labor reform and the influence of a group of requests in employee grievances that came from a same office in the analyzed sample.

Keywords: employee grievances; people management; employment relations; administration. 


\section{LISTA DE ILUSTRAÇÕES}

Figura 1 - Os processos básicos de Gestão de Pessoas....................................... 39

Figura 2 - Fotografia aérea do Hospital Estadual Américo Brasiliense .................... 48 


\section{LISTA DE QUADROS}

Quadro 1 - Novos papéis da Gestão de Pessoas ............................................... 37

Quadro 2 - Variáveis Padrão do Modelo de Direito do Trabalho na Área Social aplicado às relações de trabalho no Setor Público de Saúde no Brasil.................... 44

Quadro 3 - Análise e interpretação dos dados .................................................. 50 


\section{LISTA DE GRÁFICOS}

Gráfico 1 - Casos novos por 100.000 habitantes na Justiça do Trabalho de 2009 até 2018 20

Gráfico 2 - Assuntos mais recorrentes na Justiça do Trabalho em 2016 e 2018 ..... 21

Gráfico 3 - População total do Brasil (milhares) 32

Gráfico 4 - Pessoas de 14 anos ou mais de idade, na força de trabalho, ocupadas ou desocupadas na semana de referência - Brasil 33

Gráfico 5 - Distribuição das pessoas de 14 anos ou mais de idade, ocupadas na semana de referência, segundo a posição na ocupação do trabalho principal - Brasil - 2012-2017. 34

Gráfico 6 - Total de estabelecimentos sem vínculos e com vínculos por setor de atividade 35

Gráfico 7 - Distribuição das pessoas de 14 anos ou mais, ocupadas na semana de referência, por grupamentos de atividade econômica, Brasil - $2^{\circ}$ trimestre de 20122017 36

Gráfico 8 - Total de Reclamações Trabalhistas ajuizadas de 2010 até 2018 na OS 54 Gráfico 9 - Distribuição de Reclamações Trabalhistas conforme o rito de 2010 até 2018 na OS 55

Gráfico 10 - Distribuição de inicias por advogado ou escritório da parte contrária na OS 57

Gráfico 11 - Dendograma. 63 


\section{LISTA DE TABELAS}

Tabela 1 - Distribuição total por categorias dos discursos na OS 56

Tabela 2 - Distribuição das categorias em macrocategorias. 60

Tabela 3 - Distribuição percentual das macrocategorias (2010-2018). 62 


\section{LISTA DE SIGLAS}

\begin{tabular}{|c|c|}
\hline AME & Ambulatório Médico de Especialidades \\
\hline CTPS & Carteira de Trabalho e Previdência Social \\
\hline DP & Departamento de Pessoal \\
\hline DSC & Discurso do Sujeito Coletivo \\
\hline FAEPA & $\begin{array}{l}\text { Fundação de Apoio ao Ensino, Pesquisa e Assistência do Hospital das } \\
\text { Clínicas da Faculdade de Medicina de Ribeirão Preto da Universidade } \\
\text { de São Paulo }\end{array}$ \\
\hline GP & Gestão de Pessoas \\
\hline HEAB & Hospital Estadual Américo Brasilense \\
\hline HC-FMRP & Hospital das Clínicas da Faculdade de Medicina de Ribeirão Preto \\
\hline MTE & Ministério Público do Trabalho \\
\hline ONA & Organização Nacional de Acreditação \\
\hline OS & Organizações Sociais \\
\hline OIT & Organização Internacional do Trabalho \\
\hline $\mathrm{RH}$ & Recursos Humanos \\
\hline SUS & Sistema Único de Saúde \\
\hline TST & Tribunal Superior do Trabalho \\
\hline TRT & Tribunal Regional do Trabalho \\
\hline VT & Vara do Trabalho \\
\hline
\end{tabular}




\section{SUMÁRIO}

1 INTRODUÇÃO .......................................................................................... 15

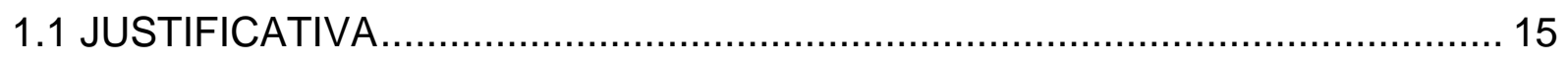

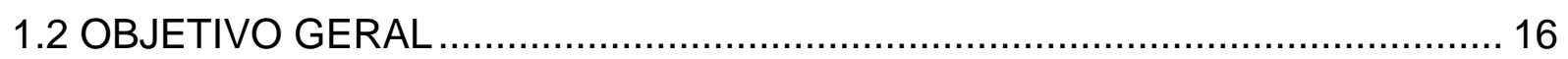

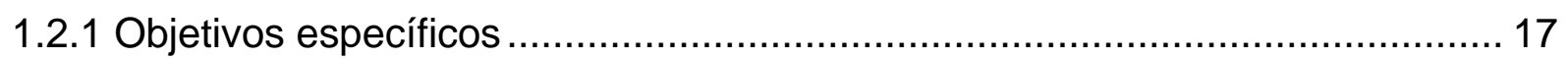

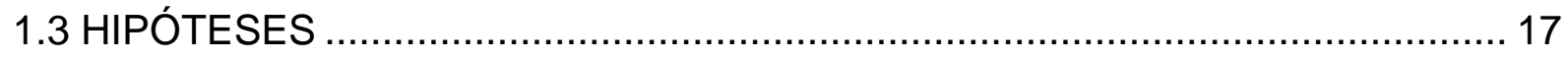

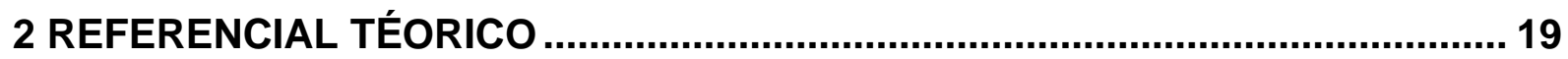

2.1 AS RECLAMAÇÕES TRABALHISTAS E O FENÔMENO DA JUDICILIZAÇÃO

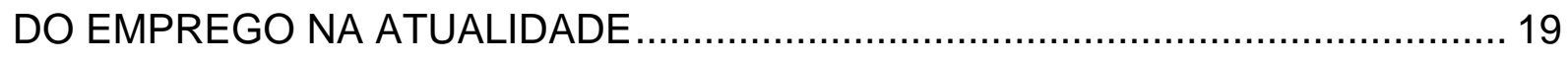

2.2 O EXERCÍCIO DA JUSTIÇA DO TRABALHO NO BRASIL ............................... 25

2.3 AS TRANSFORMAÇÕES DA SOCIEDADE E A SUA INFLUÊNCIA NO CAMPO

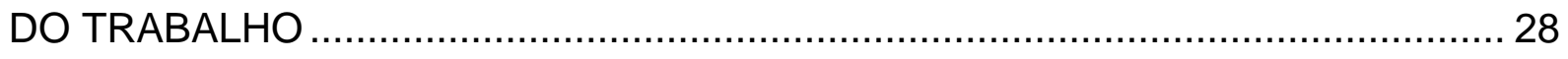

2.4 O PAPEL DA GESTÃO DE PESSOAS NAS ORGANIZAÇÕES ........................36

2.5 AS ORGANIZAÇÕES SOCIAIS E FUTURO DAS RELAÇÕES DE EMPREGO

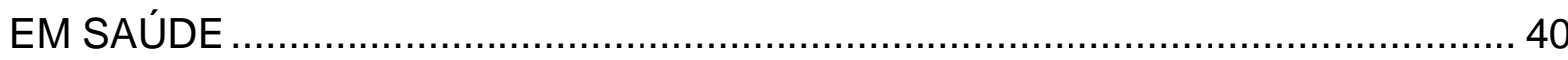

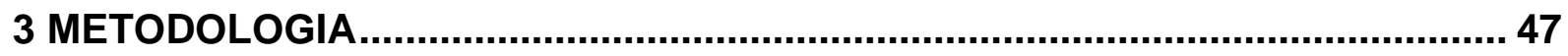

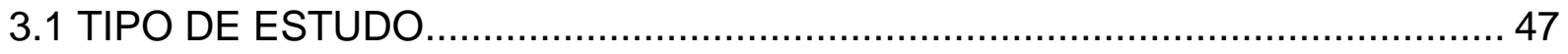

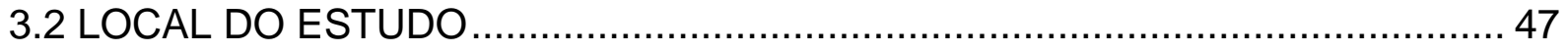

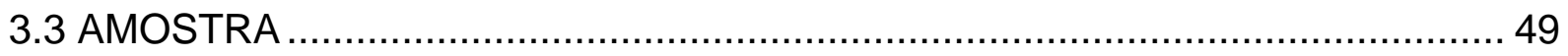

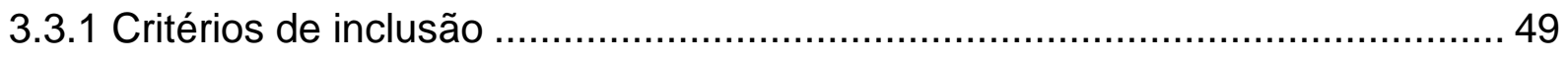

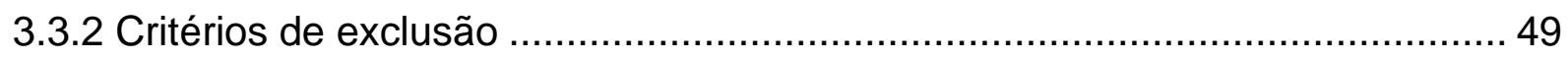

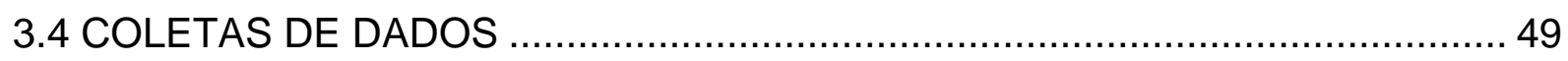

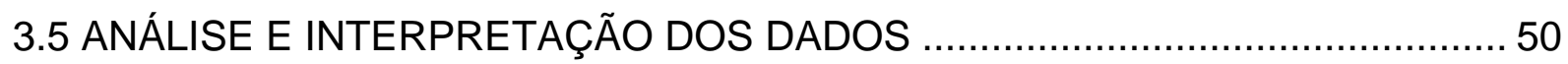

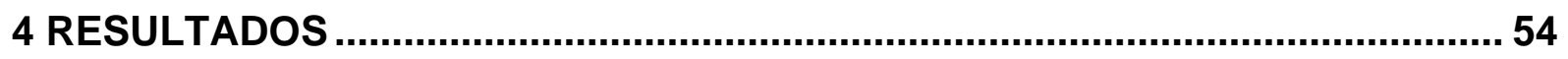

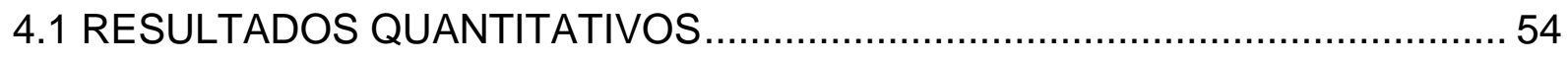

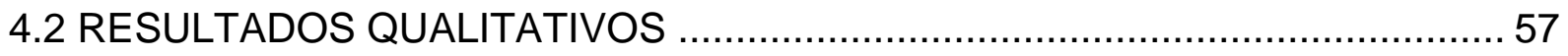

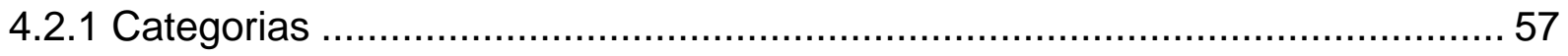

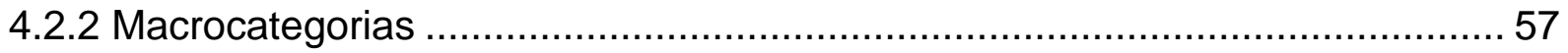




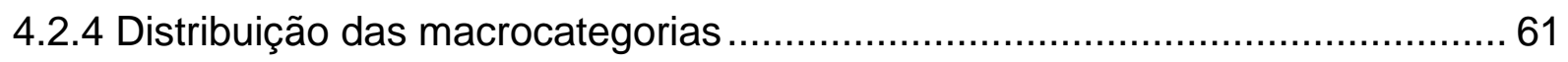

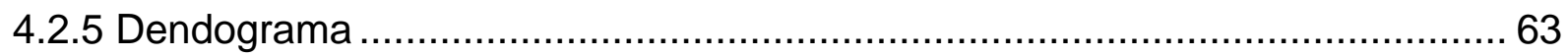

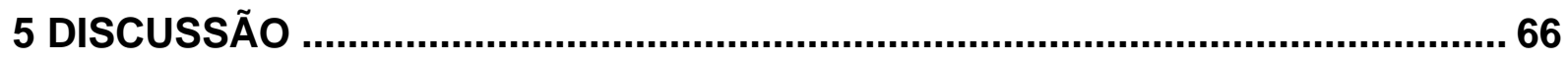

6 CONCLUSÃO........................................................................................... 73

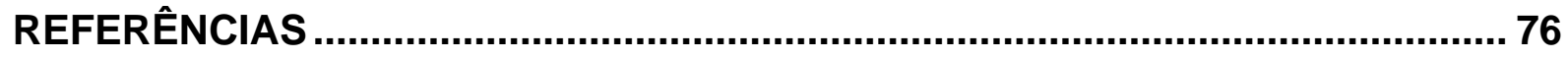

APÊNDICE A - CONSTRUÇÃO E ANÁLISE DOS DISCURSOS .......................... 82

ANEXO A - TERMO DE CONSENTIMENTO LIVRE E ESCLARECIDO ................ 97

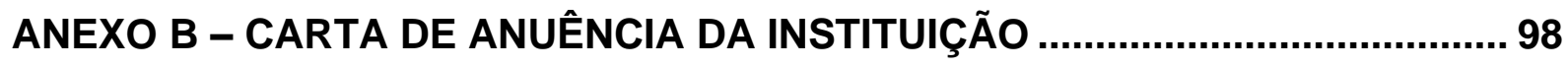

ANEXO C - APROVAÇÃO DO COMITÊ DE ÉTICA ......................................... 99 
1 INTRODUÇÃO 


\section{INTRODUÇÃO}

A origem do estudo advém de inquietações acumuladas da experiência de trabalhar na área de Recursos Humanos $(\mathrm{RH})$ e, consequetemente, lidar com os processos da Gestão de Pessoas (GP), os quais estão diretamente relacionados a administração e desempenho das organizações. Ainda, segundo Chiavenato (2014), as organizações sofrem diretamente com as influências do ambiente externo, através de: leis e regulamentos legais, os sindicatos, as condições econômicas e de trabalho e a competitividade. Além disso, também convivem com as características da dinâmica organizacional interna, relacionadas: a missão organizacional, visão, objetivos e estratégia, a cultura organizacional, a natureza das tarefas e estilo de gestão.

Neste contexto, as ações trabalhistas quase sempre estão presentes na atuação das organizações e permeiam todo o cenário. Isso torna evidente que, ao passo que ocorre o ajuizamento das ações trabalhistas - as quais são capazes de causar dentro da organização um clima de indefinição e obscuridade, um novo horizonte de possibilidades tende a ser revelado, pois a aplicação dos processos da GP como estratégia de intervenção pode potencializar de maneira satisfatória a adminstração e o desempenho das organizações e, com isso, utilizados como estratégia de mediação frente a judicialização das relações de emprego.

Dessa forma, diante dos impactos e da eminente percepção de aumento do quantitativo de ações trabalhistas na Justiça do Trabalho, despertou-se o interesse por aprofundar e desenvolver um estudo que permeasse a compreensão inicial sobre o tema em uma Organização Social (OS). Tendo por objetivo trazer à tona um entendimento mais qualificado sobre a motivação contida nos pedidos das petições iniciais, durante o ajuizamento das ações trabalhistas. A fim de revelar novas possibilidades de atuação no enfretamento dos processos da área trabalhista e ainda demonstrar a importância de aliar-se ao desenvolvimento dos processos de GP dentro das organizações.

\subsection{JUSTIFICATIVA}

Segundo o Tribunal Superior do Trabalho (TST, 2018), durante quase toda última década, o quantitativo de casos novos de ações trabalhistas na Justiça do 
Trabalho subiu a cada ano no Brasil. Tais ações são ajuizadas com a finalidade de solucionar uma controvérsia existente no campo do trabalho, entre pessoas e organizações. Entretando, o cenário sofreu uma significativa mudança, com uma redução brusca de casos novos nos anos subsequentes, fato potencialmente relacionado a aprovação da Reforma Trabalhista no Brasil em 2017, instrumentalizada pela Lei no 13.467.

Apesar da eminente redução, as ações trabalhistas ainda causam impacto nas atividades das organizações, pois em seu conteúdo existe uma diversidade de pedidos, os quais surgem a partir e para resolver conflitos advindos das relações de emprego entre empregados e empregadores. Naturalmente, tais reinvindicações podem sofrer influência de fenômenos e tendências da sociedade, bem como do conjunto de normas jurídicas que regulam essa relação, no caso, a Justiça do Trabalho do Brasil.

Os fundamentos teóricos de GP e seus processos baseados na teoria de Chiavenato (2014): agregar, aplicar, recompensar, desenvolver, manter e monitorar pessoas, atuam diretamente nas relações de emprego dentro das organizações e, podem ser a maneira mais eficaz e menos onerosa para diminuir a judicialização dessa relação. Portanto, de acordo com a atuação dos processos de GP dentro da organização, isso pode influenciar no ajuizamento das ações trabalhistas. Dessa maneira, caso for possível identificar um padrão e demonstrar quais os processos da GP tem maior impacto e relevância nos pedidos contidos nas reclamações trabalhistas, será possível determinar estratégias mais eficazes para intervenção e diminuição da controvérsia existente campo do trabalho e consequentemente as reclamações trabalhistas.

\subsection{OBJETIVO GERAL}

Identificar através de um estudo aproximativo e exploratório, as principais características das alegações contidas nos pedidos nas iniciais das ações trabalhistas de uma OS. Para assim, compreender melhor o fenômeno da judicialização das relações de emprego.

Além disso, compreender os principais aspectos da atuação dos processos de GP no âmbito organizacional, a fim de fortalecer a temática como ponto determinante 
no ajuste das relações de emprego, no ajuizamento das ações trabalhista, influenciando o desenvolvimento de estratégias preventivas e, por fim, o surgimento de novos estudos de intervenções sobre tema.

\subsubsection{Objetivos específicos}

a) categorizar os pedidos contidos nas petições iniciais trabalhistas contra uma OS de 08/2010 até 12/2018;

b) correlacionar as temáticas identificadas nas iniciais trabalhistas, em categorias e, posteriormente, formular macrocategorias conforme os processos da GP (agregar, aplicar, recompensar, manter e monitorar) de Chiavenato (2014);

c) demonstrar quais processos da GP tem maior correlação com os pedidos contidos nas iniciais das ações trabalhistas;

d) discutir sobre as principais características da sociedade e da Justiça do Trabalho no Brasil na atualidade, correlacionando os achados com os principais elementos teóricos de atuação da GP;

e) fomentar estudos de intervenção, frente à realidade demarcada pelo o estudo.

\subsection{HIPÓTESES}

a) as estratégias de GP são ser determinantes na predição, prevenção e correção das causas contidas nas reclamações trabalhistas, através da qualificação das relações de trabalho e estratégias criativas;

b) as reclamações trabalhistas estão aumentando gradativamente ao longo do tempo, com a existência de um padrão nas matérias reclamadas;

c) a Justiça do Trabalho pode proteger atos que não são morais para a organização, já que pode existir discrepância entre o ajuizamento de matérias e os processos de GP que já se fazem presentes na organização;

d) os pedidos contidos nos processos de uma OS podem apresentar alguma particularidade referente natureza jurídica da instituição. 


\title{
2 REFERENCIAL TÉORICO
}

\subsection{AS RECLAMAÇÕES TRABALHISTAS E O FENÔMENO DA JUDICILIZAÇÃO DO EMPREGO NA ATUALIDADE}

\begin{abstract}
Artigo 23
1. Todo ser humano tem direito ao trabalho, à livre escolha de emprego, a condições justas e favoráveis de trabalho e à proteção contra o desemprego.

2. Todo ser humano, sem qualquer distinção, tem direito a igual remuneração por igual trabalho.

3. Todo ser humano que trabalha tem direito a uma remuneração justa e satisfatória que the assegure, assim como à sua família, uma existência compatível com a dignidade humana e a que se acrescentarão, se necessário, outros meios de proteção social.

4. Todo ser humano tem direito a organizar sindicatos e a neles ingressar para proteção de seus interesses. (UNESCO, 2009).
\end{abstract}

$\mathrm{Na}$ atualidade, o tema da judicialização é amplamente discutido e alcança inúmeros dos contextos do cotidiano de nossa sociedade, como: saúde, política, questões sociais, entre outros pontos de conflito. Cada vez mais, a jurisdição se amplia em todo o mundo, o acesso à justiça tem avançado para tornar-se um direito de todos e, em suma, a sociedade tem passado a reconhecer seus direitos (UZZO, 2004). Dessa forma, em vista da amplitude do tema, neste capítulo, foram levantadas as principais características na judicialização das relações de emprego e a dimensão do fenômeno no Brasil.

Segundo relatório do TST (2016), o número de casos novos na Justiça do Trabalho brasileira crescia com o passar dos anos. Neste cenário, o ano de 2016 apresentou os números mais expressivos, de forma que a cada 100.000 habitantes do país, 88 ingressaram com ação ou recurso no TST, 386 nos Tribunais Regionais do Trabalho (TRT) e 1.321 nas Varas do Trabalho (VT). Isso representa um aumento de $5,1 \%$ em relação a 2015. Somente em 2016 foram ajuizados um total de 1796 processos para cada 100.000 habitantes. Em contrapartida, de acordo com relatório do TST (2018) e como demonstrado no Gráfico 1, o cenário mudou. No ano de 2018, a cada 100.000 habitantes do país, 116 ingressaram com ação ou recurso no TST, 446 nos TRT e 830 nas VT, o que representa redução de $21,4 \%$ em relação a 2017 no quantitativo. 
Gráfico 1 - Casos novos por 100.000 habitantes na Justiça do Trabalho de 2009 até 2018

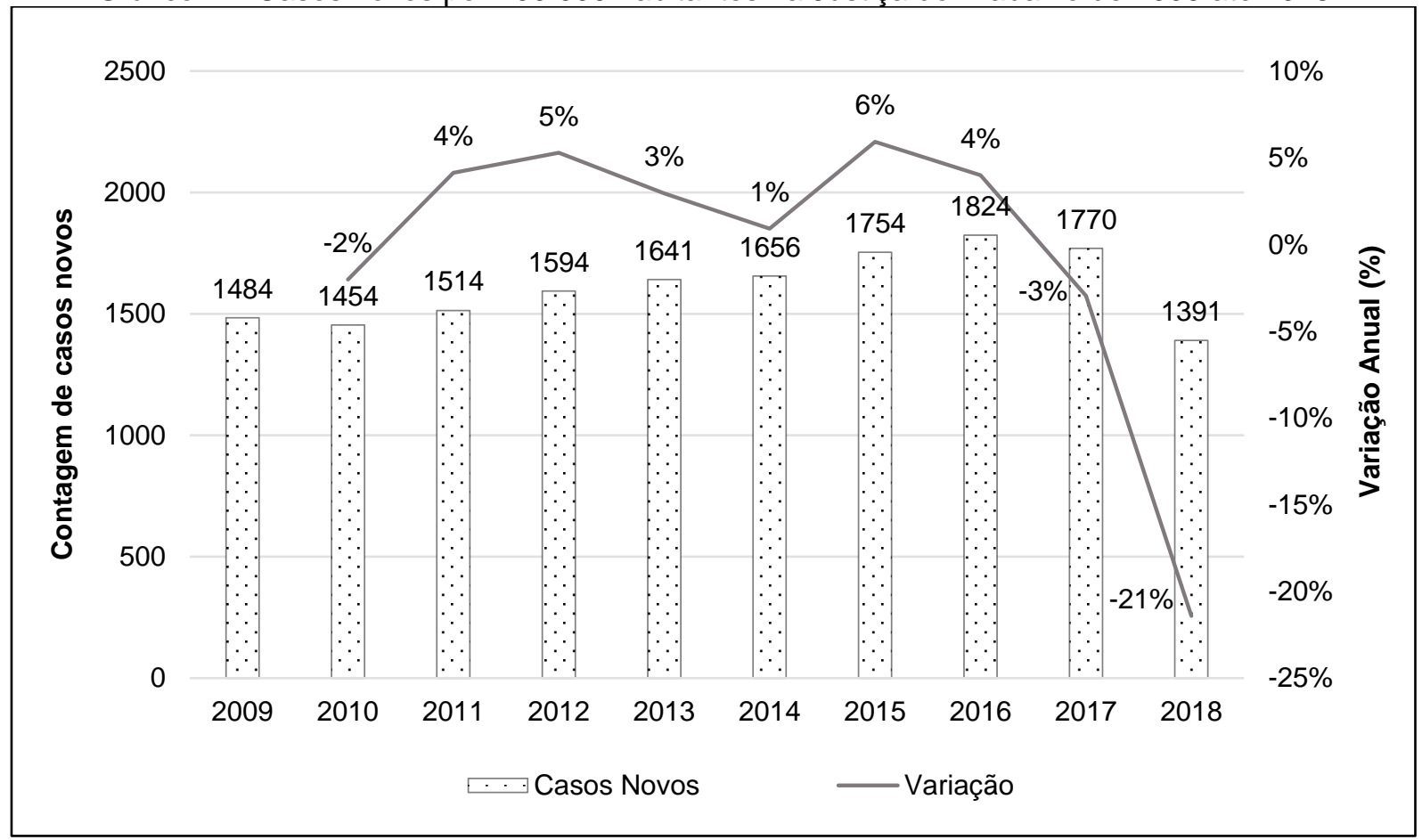

Fonte: adaptado de TST (2018).

Ainda com base no relatório, ao todo, foram pagos aos reclamantes em 2018 mais de 29 bilhões de reais. Valor composto por $46 \%$ de acordos judiciais, $42 \%$ de execução de sentença e o restante de pagamentos espontâneos. Apesar da diminuição no quantitativo de casos novos, houve aumento no valor pago aos reclamantes em comparação ao ano anterior em cerca de 5\%. (TST, 2018)

Outro dado importante, é referente as despesas da Justiça do Trabalho, que em 2018 custou cerca de 20 bilhões de reais aos cofres públicos, um custo de $R \$$ 96,00 por habitante, valor 2,6\% menor em relação ao ano anterior. Ainda é valido ressaltar que, nos últimos anos, esse valor apresentava aumentos expressivos e em 2018 manteve-se próximo ao do ano de 2017. Em contrapartida, em vista da diminuição do número de casos novos, as despesas por caso apresentaram um aumento relevante, cerca de mil reais para cada um, terminando em quase 7 mil reais para cada caso novo (TST, 2018).

Adiante, no Gráfico 2, é possível contemplar os assuntos mais recorrentes nos casos novos, frente ao maior (2016) e menor (2018) quantitativo levantados. 
Gráfico 2 - Assuntos mais recorrentes na Justiça do Trabalho em 2016 e 2018

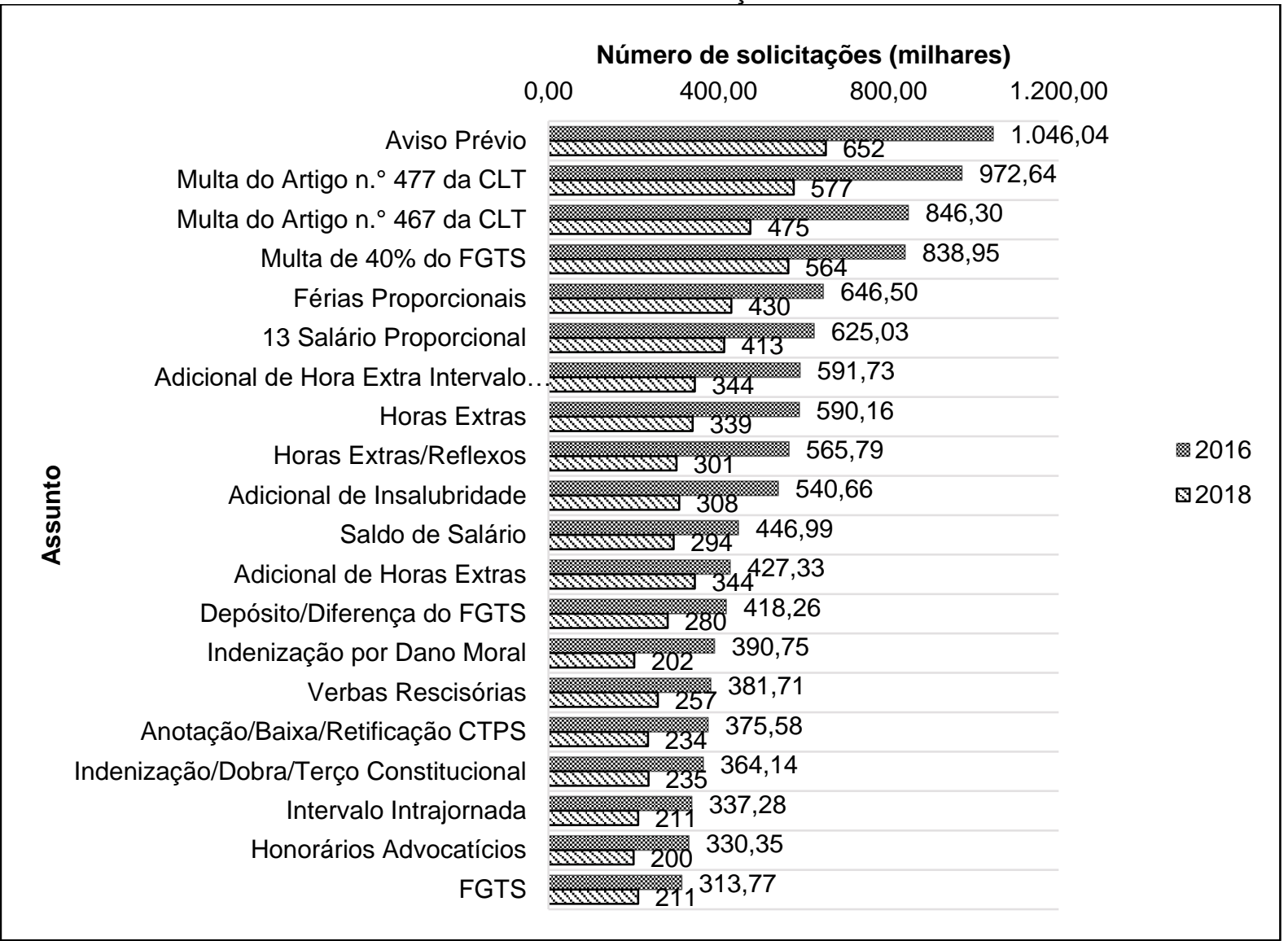

Fonte: adaptado de TST $(2016,2018)$.

A fim de compreender melhor a construção e formalização do Direito do Trabalho no contexto atual, é importante destacar os últimos dois séculos. (DELGADO 2017; NASCIMENTO, 2014). Neste período, tanto questões diretas, como indiretas as relações de emprego foram consagradas através da formação das novas constituições democráticas da época, por exemplo, as de países como: França, Alemanha e Itália (DELGADO, 2007).

No Brasil, a promulgação da Constituição Federal de 1988 foi um marco na efetivação no processo de redemocratização e reconstitucionalização do país. Através dela foi possível consagrar a existência de direitos e os fundamentos do "Estado Democrático de Direito". Isso, mais adiante, potencializou o fenômeno da judicialização e na prática aparelhou-se uma Constituição recheada de direitos individuais, sociais e coletivos que, aos poucos, em conjunto com outros fatores, como: universalização do acesso à justiça, a organização de grupos sociais e modificações na economia do Brasil influenciaram na busca e proteção de direitos (VERBICARO, 2008). No campo do trabalho, a Constituição estabeleceu princípios 
ligados ao tema trabalhista, os quais influenciaram na ordem jurídico-cultural brasileira. A proposta de instaurar um "Estado Democrático de Direito" fundamentado na dignidade humana fez com que o trabalho passasse a ser o meio de efetivar tais direitos. (FONSECA, 2006; DELGADO, 2007; DELGADO, 2017).

Desde a Constituição 1988, a negociação coletiva passou a ser uma das vias mais importantes para a solução de conflitos entre empregados e empregadores. Sua concepção foi um impulso relevante experimentado pela evolução jurídica brasileira, pois trouxe consigo um modelo mais democrático de administração de conflitos (DELGADO, 2017).

A partir disso e diante de um contexto mais atual, anterior as reformas recentes, segundo Uzzo (2004), uma parcela dos problemas vividos na Justiça do Trabalho pode ser analisada a partir das decisões do Poder Público. Desde que houve o surgimento das primeiras instituições advindas da Justiça Comum, as quais avançaram para a especificidade da Justiça do Trabalho e, por fim, findaram no TST. Acabaram por ser concebidas a partir de estrutura enxuta, baseada em uma pirâmide: VT, TRT e o TST. Tal estrutura pouco sofreu alteração ao longo dos anos, na verdade, a carga de processos recebida por essa tríade é infinitamente maior do que sua capacidade de processamento. Para o Estado, pouco importa investir, já que é de seu interesse diminuir o custo público e a cada dia afastar-se da execução dos serviços, mantendo uma estrutura arcaica para enfrentar uma problemática que só cresce com o passar do tempo.

Neste ponto, a valorização do trabalho regulado cresceu na lógica ocidental e também no Brasil - apesar da valorização das modalidades autônomas em detrimento da lógica capitalista, comparado ao emprego regulamentado. Por isso, o emprego regulamentado por normas jurídicas despontou em favor da introdução do trabalhador na esfera capitalista. Principalmente por fornecer maior afirmação individual, familiar, social, econômica e ética, ou seja, satisfaz de forma mais consciente, as necessidades socioeconômicas elencadas pela razão capitalista (DELGADO, 2007).

De certa forma, é possível postular que a administração pública do país possa ter falhado em sua obrigação de implementar políticas públicas de trabalho e emprego de forma eficaz, manteve-se distante de resolver a base do problema, como a baixa escolaridade e, mais adiante, a falta de qualificação do trabalhador brasileiro. Dessa maneira, a sociedade exige de forma direta ou através de seus representantes legais 
o cumprimento de seus direitos, mesmo que seja através do Poder Judiciário (FONSECA, 2006).

$\mathrm{Na}$ democracia brasileira, um dos maiores desafios do século XXI será identificar de maneira efetiva os direitos fundamentais do trabalho. Ou seja, de nada adiantará reconhecer a estrutura e a eficácia jurídica dos direitos, caso sua correlação com as práticas sociais não estejam a contento. Também é valido destacar que, no Brasil, as relações de trabalho estão cercadas por um ideal elitista, o que é resultado de uma estratégia voltada para concentração de renda. Esse ambiente acaba por segregar a população em questões de civilidade - delimitação das normas de convivência nas relações de trabalho. Isso pode ser constatado através do acesso ao campo jurídico, o qual quase sempre foi urbanizado. O contexto fez com que os indivíduos se tornassem regidos pela lógica do Direito do Trabalho e a formalização do trabalho (DELGADO, 2007).

Portanto, é extremamente válido pensar no potencial do conteúdo jurídico, diante das questões do trabalho. O mesmo pode gerar questionamentos e potencialização tendências como: a desregulamentação e/ou flexibilização trabalhista, ou seja, atuar na expansão dos direitos fundamentais. Diante dessa possibilidade de extensão, é imprescindível que ocorra o desenvolvimento de um ramo especializado e uma ampliação de sua capacidade normativa, para assim, adaptar esse campo do Direito, a dinâmica do trabalho contemporâneo. Por fim, vale sintetizar que o avanço desses Direitos percorre por três aspectos: a crescente busca pela efetivação do Direito do Trabalho, o alargamento desse segmento jurídico e pela extensão dos direitos fundamentais trabalhistas a determinados vínculos não empregatícios (DELGADO, 2007).

Frente a esse futuro, no momento atual, é possível observar que diversos países, como: Brasil (2017), Alemanha (2003-2005), México (2012), Espanha (20102012) e França (2016-2017) tem passado por reformas de cunho trabalhista. E os impactos causados por tais reformas perpassam pela disputa entre as instituições que efetivam as normas e o mercado de trabalho, além de sofrer com outras influências, como políticas públicas e a dinâmica da economia, conforme a característica de cada localidade. Apesar das diferenças de cada país, é possível notar que no campo jurídicos existe a tendência de crescimento da desvalorização da força de trabalho e redução de proteção aos trabalhadores; no campo econômico, a generalização da 
efetividade das reformas é limitada, ou não se efetivam ou causam impactos controversos; no campo social existe uma similaridade, que demonstra piora na venda e uso da força de trabalho, ou seja, crescem o volume de contratos precários e os típicos pioram (FILGUEIRAS, LIMA, SOUZA, 2019)

No caso do Brasil, após a promulgação Lei 13.467 de 2017, conhecida como a Lei da Reforma Trabalhista, houve a ampliação da liberdade dos empregadores em determinar as condições de contratação, o uso da força de trabalho e remuneração. De forma que, as empresas passam a ter maior responsabilidade no processo de definição das regras presente nas relações de emprego e restringindo a participação das organizações de trabalhadores e do Estado. Tais alterações aumentaram a insegurança dos trabalhadores, através da perda de direitos e a diminuição da proteção social. (KREIN, 2018; GALVÃO 2019).

A reforma também pode promover a diminuição da representatividade e esvaziar as instituições sindicais na qualidade de organizações de classe. Pois mexeu com a estrutura sindical, por: alterar as bases de representação, minar as bases de financiamento das entidades, redefinir o papel dos sindicatos e oferecendo certa segurança para que as práticas patronais não sejam questionadas no judiciário. (KREIN, 2018).

Por fim, é indispensável colocar em pauta discussões sobre a reforma sindical e trabalhista no Brasil, a fim de ajustar as relações de emprego. Da mesma maneira, é essencial pensar em novas formas de representar os trabalhadores. Isso é fundamental diante da exploração de direitos, além de ser decisivo na efetivação da representação dos trabalhadores e suas demandas (PESSANHA; ARTUR, 2013).

Frente a dimensão da judicialização no campo do trabalho é preciso levar em consideração que existem inúmeras configurações econômicas entre as nações e com desfechos distintos. Um exemplo é a relação entre os sindicatos e a defesa dos direitos trabalhistas, que tem como divergência mais atuante, a ausência ou presença da mediação do Estado e o modo como ocorre a intervenção deste na relação entre as partes (PESSANHA; ARTUR, 2013). 


\title{
2.2 O EXERCÍCIO DA JUSTIÇA DO TRABALHO NO BRASIL
}

\begin{abstract}
O direito do trabalho vive atualmente um conflito entre as suas concepções, a protecionista, acusada de hipergarantista, de afetar o desenvolvimento econômico e a livre iniciativa, e a reformista que defende a flexibilização das leis e a reavaliação, no plano teórico, dos seus princípios e funções, pondose a flexibilização como uma polêmica reação contrária à rigidez da legislação tutelar do trabalhador. (NASCIMENTO, 2014, p. 60).
\end{abstract}

Para compreender o exercício da Justiça do Trabalho brasileira, é preciso buscar informações frente a evolução histórica do direito do trabalho, suas principais transformações, regulamentações e organização. A partir disso e a fim de delimitar a extensão do estudo, optou-se por segmentar neste capitulo os achados relacionados ao tema a partir da Revolução Industrial do século XVIII.

Nascimento (2014) cita a existência de diversos critérios de periodizações referente a trajetória histórica do Direito do Trabalho, uma delas divide a história segundo fatos marcantes, com início na Revolução Industrial do século XVIII e a questão social; o pensamento liberal; o intervencionismo do Estado; as primeiras leis; a construção dogmática; a concepção heterotutelar do trabalhador; a concepção econômica da flexibilização; as transformações no mundo do trabalho; o Direito do Trabalho pós-moderno ou contemporâneo.

No campo histórico, o Direito do Trabalho se confunde com o Direito Coletivo do Trabalho e por isso devem ser visitados em conjunto. Posto isso, a Revolução Industrial no século XVIII acabou por arrimar a retomada do propósito associativo, em vista da formação da classe proletária da época - a qual emergiu do desequilíbrio social gerado pela relação de exploração entre o capital e trabalho. O principal objetivo na época era obter melhorias nas condições de trabalho e dos direitos comuns (CHOHFI, T; CHOHFI, M. C., 2011). Este período é pretendido como precursor do desenvolvimento do Direito do Trabalho e o contrato de trabalho (MARTINS, 2016).

Apesar dos avanços obtidos nesta época, ocorreram também certos recuos, como por exemplo, o surgimento de leis penais para punição de eventuais associações de trabalhadores e outras retaliações. Contudo, com o passar do tempo, cada vez mais, ocorreu o fortalecimento das primeiras agremiações de caráter sindical. Até que na Inglaterra no século XIX, formou-se a trade unions, uma organização de trabalhadores, com abstenção legal e sem intervenção do Estado, com ideais de organização das vontades coletivas e efetivação das conquistas da 
classe trabalhadora, considerada a predecessora dos sindicatos $(\mathrm{CHOHFI}, \mathrm{T}$; CHOHFI, M. C., 2011; FREITAS; FUGULIN; FERNANDES, 2006; PESSANHA; ARTUR, 2013).

Após a Segunda Guerra Mundial o corporativismo que buscava organizar a economia a favor do Estado, através da promoção do interesse nacional e da imposição de regras, foi substituído pelo ideal de liberdade sindical, embasado em políticas democráticas e reforçados ainda na Declaração Universal dos Direitos Humanos de 1948 - que sancionou o direito de todos à associação sindical, sem a influência de qualquer sujeito, inclusive do Estado e ainda previa direitos aos trabalhadores, como: limitação das horas trabalhadas, férias, repouso e lazer, entre outras. (CHOHFI, T; CHOHFI, M. C., 2011; MARTINS, 2016).

Segundo Martins (2016), a partir deste período uma nova frente toma forma, a crescente necessidade de separação entre os aspectos econômicos e sociais leva o neoliberalismo propagar que as contratações e os salários deveriam ser regulados pela lei de oferta e procura, ou seja, de acordo com o mercado. Portanto, o Estado deveria deixar de intervir em condições reguladas pela economia, inclusive, isso pode ser verificado através da Constituição de 1988 que trata os temas de maneira separada e prega um Estado neoliberalista.

No Brasil, a evolução do movimento sindical foi parecida com o movimento global, com sucessos e retaliações. Apesar de uma experiência mais liberal durante a Primeira República, o país pouco evoluiu no período, com a conquista de apenas algumas leis protetivas. (PESSANHA; ARTUR, 2013). O contexto da época era de um país agrário, no qual mais da metade da população vivia na área rural e permanecia exposta as heranças de um passado escravocrata. Os trabalhadores careciam de direitos e eram submetidos a condições de trabalho degradantes (NOLETO, 2018)

Entretanto, com a Revolução de 30 houve o lançamento das bases institucionais para o progresso da industrialização, além da entrada do Estado como mediador dos conflitos trabalhistas e o surgimento do Ministério do Trabalho, Indústria e Comércio. O então presidente Getúlio Vargas impôs o projeto de uma justiça especial do trabalho em 1941 e posteriormente a Consolidação das Leis do Trabalho (CLT), que foi instituída pelo Decreto-Lei n. 5.452 de 1943. Tal consolidação sofre, desde o seu nascimento, com o debate entre liberais (hoje neoliberais) e seus críticos. Inclusive, tal discordância eventualmente atrapalha o avanço das discussões frente 
aos vícios desse modelo tido como "protetivo" desde sua elaboração na Era Vargas. Isso tudo diminui a possibilidade de aproveitar um contexto mais democrático experimentado no Brasil na atualidade, o que tornaria mais fácil aperfeiçoar esse modelo protetivo e resistente ao tempo (PESSANHA; ARTUR, 2013).

Apesar dos avanços, com o passar do tempo, foram necessárias algumas alterações para solucionar as lacunas não preenchidas pela CLT e, gradativamente, foram instituídos na constituição, itens como: o direito de greve e a unicidade sindical - além de outros temas que foram ou ainda estão em edição até a atualidade (CHOHFI, T; CHOHFI, M. C., 2011; FREITAS; FUGULIN; FERNANDES, 2006).

A relação jurídica do Direito do Trabalho quase sempre envolve o trabalhador, empresa e o Estado. O trabalhador disponibiliza sua força de trabalho a outrem, a empresa é aquela que faz uso dessa força de trabalho, a fim de atingir seus objetivos - inclusive ela é considerada a parte mais forte da relação. O Estado atua para minimizar ou regularizar esse relacionamento, na forma de não viabilizar a exploração do mais forte sobre o mais fraco. Existem ainda, outros sujeitos atuantes no Direto do Trabalho, como os sindicatos, a Organização Internacional do Trabalho (OIT), o Ministério Público do Trabalho e o Ministério do Trabalho e Emprego ( $\mathrm{CHOHFI,} \mathrm{T;}$ CHOHFI, M. C., 2011).

Apesar de todos esses sujeitos, relações e variáveis conectadas a realidade do Direito do Trabalho, órgãos do Poder Judiciário, tribunais e juízes do trabalho imprimem um papel fundamental em seu exercício, definido inclusive na Constituição do Brasil. O Judiciário faz parte de uma divisão de poderes do país, conforme descrito na constituição no art. 2: "São Poderes da União, independentes e harmônicos entre si, o Legislativo, o Executivo e o Judiciário". O Poder Judiciário também é composto, dentre outros órgãos, pela Justiça do Trabalho, que teve sua competência definida na Constituição Federal de 1988:

Art. 114. Compete à Justiça do Trabalho processar e julgar:

I - as ações oriundas da relação de trabalho, abrangidos os entes de direito público externo e da administração pública direta e indireta da União, dos Estados, do Distrito Federal e dos Municípios;

II - as ações que envolvam exercício do direito de greve;

III - as ações sobre representação sindical, entre sindicatos, entre sindicatos e trabalhadores, e entre sindicatos e empregadores;

IV - os mandados de segurança, habeas corpus e habeas data, quando $o$ ato questionado envolver matéria sujeita à sua jurisdição;

$\mathrm{V}$ - os conflitos de competência entre órgãos com jurisdição trabalhista, ressalvado o disposto no art. 102, I, o; 
$\mathrm{VI}$ - as ações de indenização por dano moral ou patrimonial, decorrentes da relação de trabalho;

VII - as ações relativas às penalidades administrativas impostas aos empregadores pelos órgãos de fiscalização das relações de trabalho;

VIII - a execução, de ofício, das contribuições sociais previstas no art. 195, I, a, e II, e seus acréscimos legais, decorrentes das sentenças que proferir;

IX - outras controvérsias decorrentes da relação de trabalho, na forma da lei. $\S 1^{\circ}$ Frustrada a negociação coletiva, as partes poderão eleger árbitros.

$\S 2^{\circ}$ Recusando-se qualquer das partes à negociação coletiva ou à arbitragem, é facultado às mesmas, de comum acordo, ajuizar dissídio coletivo de natureza econômica, podendo a Justiça do Trabalho decidir o conflito, respeitadas as disposições mínimas legais de proteção ao trabalho, bem como as convencionadas anteriormente.

$\S$ 3ํㅡㄹ Em caso de greve em atividade essencial, com possibilidade de lesão do interesse público, o Ministério Público do Trabalho poderá ajuizar dissídio coletivo, competindo à Justiça do Trabalho decidir o conflito.

\title{
2.3 AS TRANSFORMAÇÕES DA SOCIEDADE E A SUA INFLUÊNCIA NO CAMPO DO TRABALHO
}

\begin{abstract}
As mudanças são cada vez mais velozes e intensas no ambiente, nas organizações e nas pessoas. O mundo moderno se caracteriza por tendências que envolvem: globalização, tecnologia, informação, conhecimento, serviços, ênfase no cliente, qualidade, produtividade, competitividade, sustentabilidade. Todas essas tendências estão afetando e continuarão a afetar a maneira pela qual as organizações utilizam as pessoas. (CHIAVENATO, 2014, p. 40)
\end{abstract}

Os processos referidos a GP estão intimamente ligados a configuração da sociedade e das organizações. Dessa forma, para compreender a extensão de seus processos, adiante foram levantados os principais aspectos históricos e características da sociedade na atualidade, bem como seu impacto nas organizações. Com o objetivo final de compreender melhor as tendências do mercado de trabalho global, o mercado de trabalho brasileiro e os impactos já evidenciados nos processos de GP para acompanhar essas mudanças.

Para cada nova característica alterada do mercado, modificações também são exigidas nas organizações, as quais vão desde a concepção do trabalho a processos e atividades vinculadas à administração dos recursos humanos. Neste campo, o processo de trabalho evoluiu de um modelo taylorista e fordista, com propriedades em favor da alienação, fragmentação e perda da subjetividade do trabalhador - para ao longo do tempo, adquirir novos formatos, como o toyotismo que customizou a produção e trouxe mais flexibilidade aos processos de trabalho ( $\mathrm{LOCH}$; CORREA, 2004). 
Desde o século passado Rifkin (1995) abordava o tema de que todo esse desenvolvimento tecnológico alcançado pela sociedade iria mostrar o seu real impacto. O desemprego global atingia níveis históricos desde a grande depressão de 1930 e as substituições do homem pelas novas tecnologias avançavam a cada dia, ao ponto de citar que cada nação passaria a ter de repensar o papel dos seres humanos no processo social. Inclusive, isso poderia se tornar a questão de maior discussão no século XXI. Apesar das evidências, constantemente a sociedade insiste que os tempos econômicos irão melhorar e a geração de empregos terá sua retomada. Isso dificilmente irá acontecer, já que as organizações constantemente melhoram seu processo produtivo e são mais competitivas - o que inevitavelmente diminuirá a necessidade da força de trabalho.

Outro autor da época, Bridges (1995) também observou que os empregos estavam desaparecendo e de forma definitiva. A principal justificativa para isso é de que o trabalho também estava mudando. A velocidade das mudanças da época, eram bem mais frequentes, principalmente pela influência da tecnologia. Para o autor, os principais motivos da mudança no trabalho no período, eram: a informatização do ambiente de trabalho, a velocidade do processamento através de bancos de dados e a evolução das tecnologias das comunicações com seu "efeito multiplicador", em que o tempo e a distância não são mais aspectos limitantes.

De acordo com Chiavenato (2014), a partir da Revolução Industrial as mudanças e transformações no cenário mundial influenciaram as organizações, no decorrer do século XX é quando surge o novo conceito de trabalho e o mesmo assume sua configuração atual. $\mathrm{O}$ autor divide o século em três "Eras" organizacionais distintas: a Era da Industrialização Clássica, a Era da Industrialização Neoclássica e a Era da Informação. Em suma, a primeira foi influenciada pela intensificação da industrialização em escala mundial e o surgimento dos países desenvolvidos, que adotavam uma estrutura organizacional burocrática e centralizadora; a segunda corresponde ao período de 1950 e 1990, após a Segunda Guerra Mundial as transações passaram a ser de larga escala e o modelo anterior passou a enfrentar dificuldades em um ambiente competitivo, as estruturas organizacionais da época adotaram um modelo matricial que pouco conseguia avançar, pois esbarravam em remover a estrutura burocrática de sua velha base funcional; a terceira tem início a partir de 1990 e corresponde a época atual, a Era do Conhecimento, atualmente as 
mudanças são imprevisíveis e o mundo tornou-se interligado e o capital humano e intelectual passam a ter papel de destaque, o empregou passou a migrar da indústria para o setor de serviços e a organizações passaram a ter um desenho orgânico, com equipes autônomas, ágeis e que se adaptam ao contexto inserido.

Sob o aspecto da configuração social Bauman (2007) retrata que sociedade tem passado pela mudança de uma fase "sólida" da modernidade para a "líquida". Isso impacta diretamente nas organizações sociais (organização da sociedade), que são responsáveis por manter as limitações das escolhas individuais, a repetição das rotinas e padrões de comportamento aceitável. O Estado tem se distanciado do poder e da política pela incapacidade de atuar em um espaço global ou extraterritorial. Esse enfraquecimento tem tornado a política incerta e a falta de poder tem desmembrado as instituições políticas, suas iniciativas tem tornado os empreendimentos menos relevantes aos problemas dos cidadãos. Outra transformação relevante cabe aos laços humanos, que já foram pautados pela segurança e investimento de tempo, e condiziam com os sacrifícios dos interesses individuas imediatos em favor de outro. $\mathrm{Na}$ atualidade, os indivíduos se tornaram frágeis e permanecem apoiados em relações de curto prazo, o pensamento, o planejamento de longo prazo e o enfraquecimento das estruturas sociais resume as ações dos indivíduos em episódios de curto prazo que não combinam mais com conceitos de "desenvolvimento", "maturação", "carreira" ou "progresso".

$\mathrm{Na}$ atualidade é possível constatar tais perspectivas, já que a sociedade moderna passou enfrentar uma gama de problemas de natureza complexa e que surgem como reflexo da interação entre diferentes fatores que não existiam há tempos atrás, como: concentrações urbanas, crise econômica, esgotamento de recursos naturais, transportes, educação, ecologia, evolução tecnológica, globalização, desemprego, inflação, criminalidade, catástrofes naturais ou artificiais, epidemias, migração, além de diversos outros problemas (MAXIMINIANO, 2012).

Apesar de tais problemas, Friedman (2014) utiliza da interpretação de que o "mundo é plano", para analisar que as recentes evoluções da tecnologia e da comunicação como responsáveis pelo "achatamento" e consequentemente pela interligação dos centros de conhecimento do planeta, ou seja, isso tem transformado tudo em uma única rede global capaz de precipitar uma nova era de prosperidade, inovação e colaboração entre empresas, comunidades e indivíduos. Portanto, através 
das conexões entre os indivíduos será possível reformular os conceitos de distância, tempo e trabalho.

Ao abordar as transformações globais da atualidade Lucena (2017) retrata os principais desafios do homem, através de três forças: a primeira no campo tecnológico, guiada pela explosão tecnológica que tem gerado a obsolescência humana e das organizações, a falta de controle do ambiente e o favorecimento da qualidade e o custo; a segunda, no campo social, voltada para busca pela satisfação da existência humana, com os movimentos de defesa dos Direitos Humanos e da ecologia, a busca pela autogestão (processo de conscientização das pessoas) e a organização dos próprios cidadãos para resolver problemas sociais; e a terceira, no campo econômico, a própria mudança na natureza das organizações, encabeçada pela globalização da economia.

Segundo Maximiniano (2012) para lidar com essa quantidade de problemas e variáveis, as organizações utilizam de um enfoque sistemático como ferramenta para visualizar a interação entre os componentes. Portanto, uma organização nada mais é que um sistema complexo e organizado, em que os elementos em conjunto formam um unitário. Tal conjunto depende do comportamento das pessoas e não somente aspectos técnicos. Ou seja, os sistemas sociais têm grande importância, já que são formados por pessoas e suas necessidades, sentimentos e atitudes. Esse sistema tem muito mais importância do que os sistemas técnicos, que são formados pelas máquinas, métodos de trabalho, tecnologia, estrutura organizacional e as normas e procedimentos. Por fim, a sociedade moderna trouxe consigo a ideia clara sobre a relação entre a produtividade e o desempenho das organizações.

Dessa forma, as transformações no mundo têm a afetado as relações de trabalho e relevado problemas de ordem global. Como a diminuição dos empregos e concepção de novas formas de vínculos de empregado e o aumento da produtividade com uma menor quantidade de mão de obra - apoiado no desenvolvimento tecnológico que fez produção aumentar e a quantidade de trabalho diminuir (NASCIMENTO, 2014).

No Brasil é possível questionar até que ponto somos na atualidade tão diferentes do passado, aparentemente a desigualdade perene tem como causa a falta de um projeto nacional de desenvolvimento, o qual seria capaz de suprir as nossas 
carências e ideais como povo e nação. Na verdade, continuamos a copiar modelos de países com passado e cultura bem distintos do nosso (LUCENA, 2017).

A fim de observar tais transformações sociais no Brasil e compreender o seu impacto no mercado de trabalho, é indispensável observar dados demográficos. O Gráfico 3 dispõe sobre o crescimento populacional. O país saiu de 197 milhões habitantes em 2012 para 206 milhões em 2017, com uma variação de crescimento médio de $0,2 \%$ a cada trimestre. Contudo, apesar do aumento, essa taxa de crescimento trimestral vem diminuindo. No início de 2012 a população cresceu em média $0,23 \%$, desde então esse indicador marcha no sentido de uma diminuição gradativa, atualmente, no segundo trimestre de 2017 a taxa está em $0,18 \%$.

Gráfico 3 - População total do Brasil (milhares)

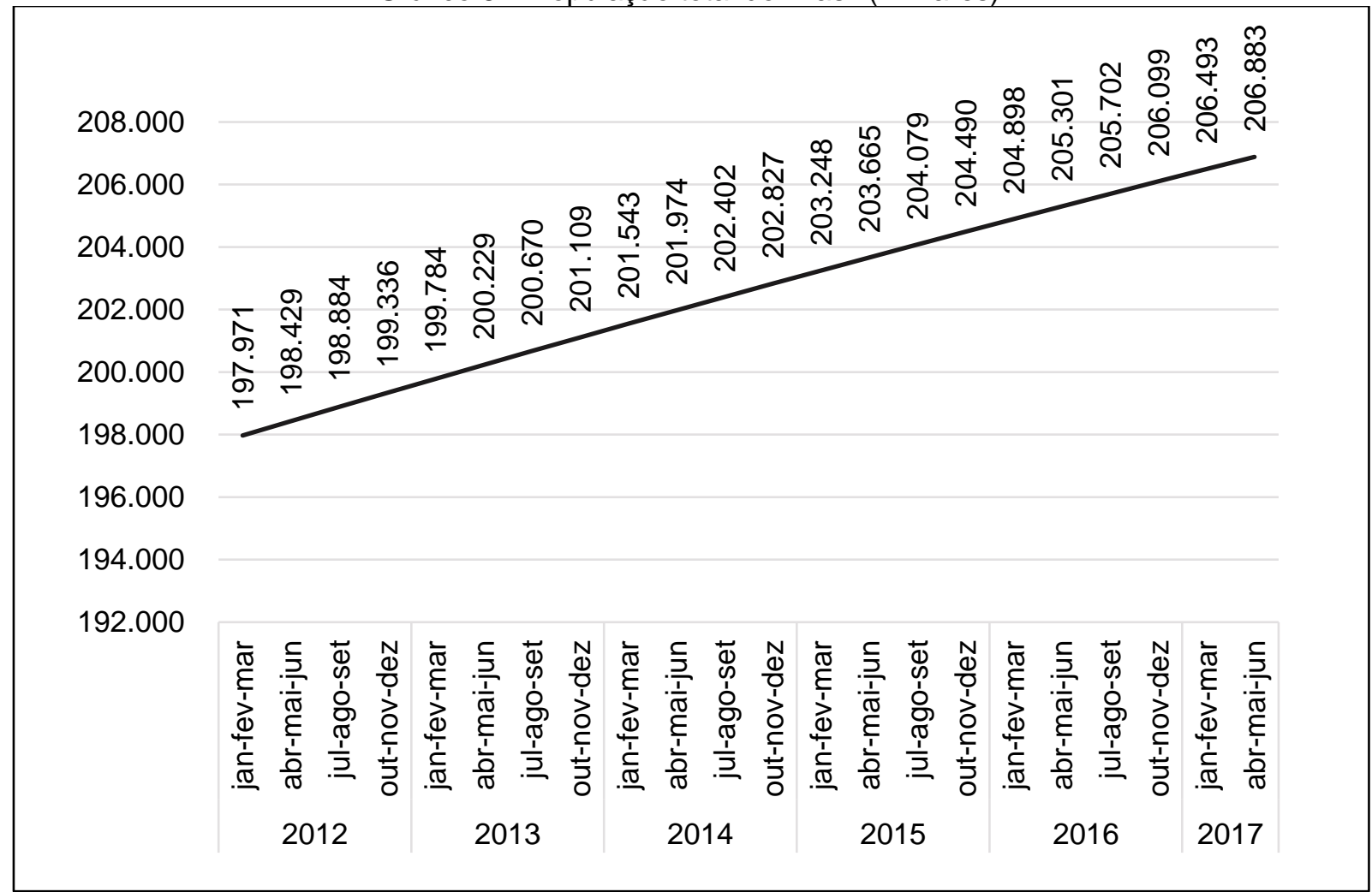

Fonte: adaptado IBGE (2017).

A seguir e conforme o Gráfico 4, é possível visualizar que no Brasil, a força de trabalho vem aumentando a cada dia. Em 2012 o país tinha em média 95 milhões de pessoas na força de trabalho, atingindo ao número de 103 milhões em 2017. Apesar desse crescimento, a força de trabalho ocupada no país, manteve-se em um número próximo ao de 2012, ou seja, em torno de 90 milhões de pessoas - basicamente 0 país tem uma força de trabalho maior a cada ano, porém, com um número de 
ocupação estagnado ao longo do período analisado. O desemprego conservou os mesmos valores numéricos por um bom período, com poucas oscilações. Contudo, é possível verificar que nos últimos anos houve um crescimento constante da taxa desemprego, em que no segundo trimestre de 2017, o país chegou a ter 13 milhões de desempregados.

Gráfico 4 - Pessoas de 14 anos ou mais de idade, na força de trabalho, ocupadas ou desocupadas na semana de referência - Brasil

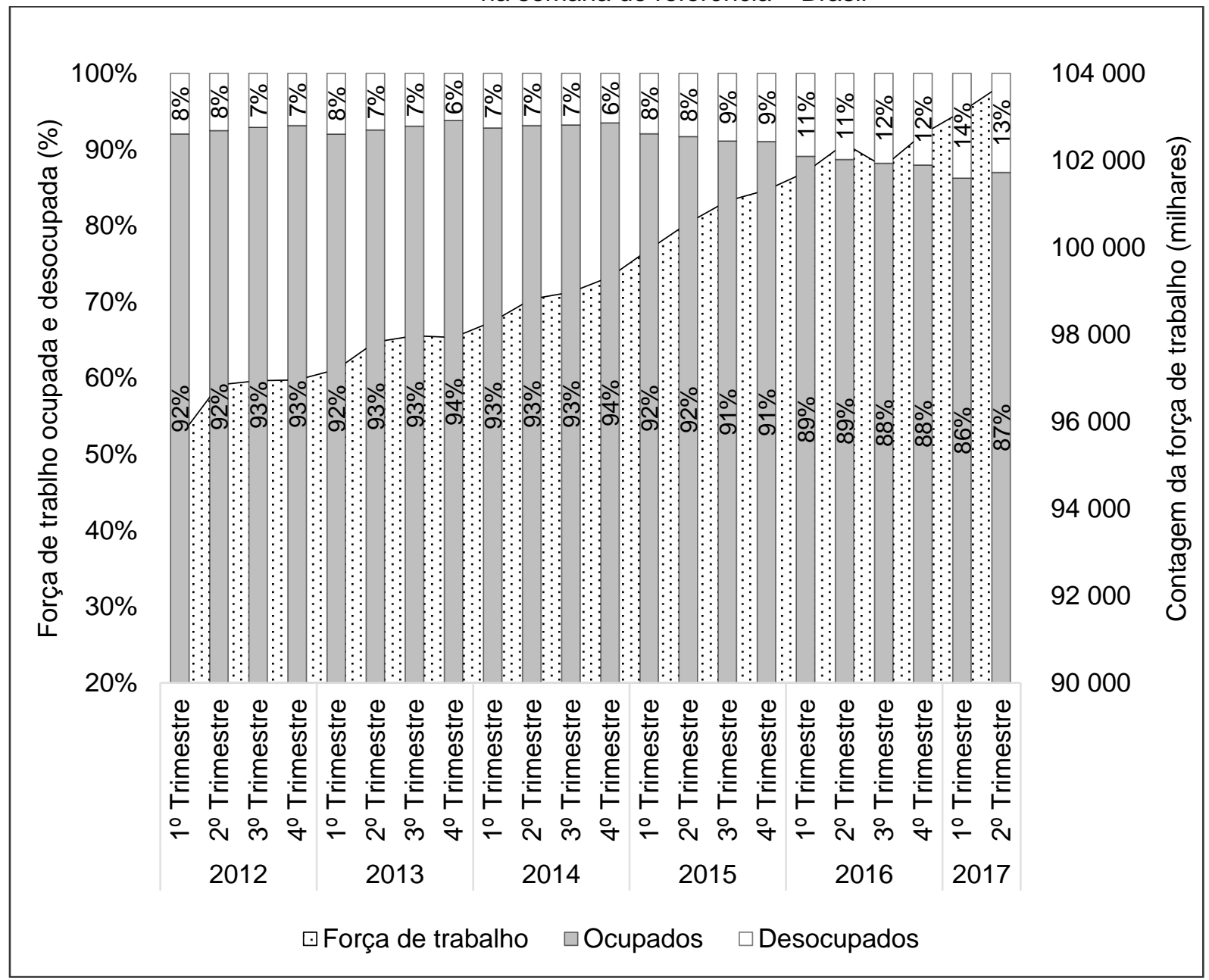

Fonte: adaptado IBGE (2017).

O mercado de trabalho brasileiro, além de enfrentar o problema do aumento da taxa de desemprego, também precisa gerenciar a piora nas condições de emprego, pois a economia informal tem tomado conta do mercado de trabalho, ou seja, os trabalhadores sem carteira assinada e conta própria estão sujeitas a uma proteção social menor, comparado ao trabalho formal. O país teve uma baixa absorção de mãode-obra ao longo do tempo, principalmente em função do processo de modernização tecnológica e pelas baixas taxas de crescimento econômico no país desde os anos 
80. Isso reflete consideravelmente na taxa de desemprego, que acompanha o próprio crescimento econômico, ou seja, a queda do nível de atividade do país reflete no aumento da taxa de desemprego (VASCONCELLOS et. al., 2013).

A série histórica do Gráfico 5 demonstra a distribuição de pessoas ocupadas, conforme o tipo de ocupação. É possível visualizar uma tendência na diminuição de empregados no setor privado, com algumas variações. Em contrapartida, existe um aumento do número de trabalhadores por conta-própria, passando em média de 20,5 milhões em 2012 para 22,5 milhões em 2017 ao longo de toda a série histórica.

Gráfico 5 - Distribuição das pessoas de 14 anos ou mais de idade, ocupadas na semana de referência, segundo a posição na ocupação do trabalho principal - Brasil - 2012-2017

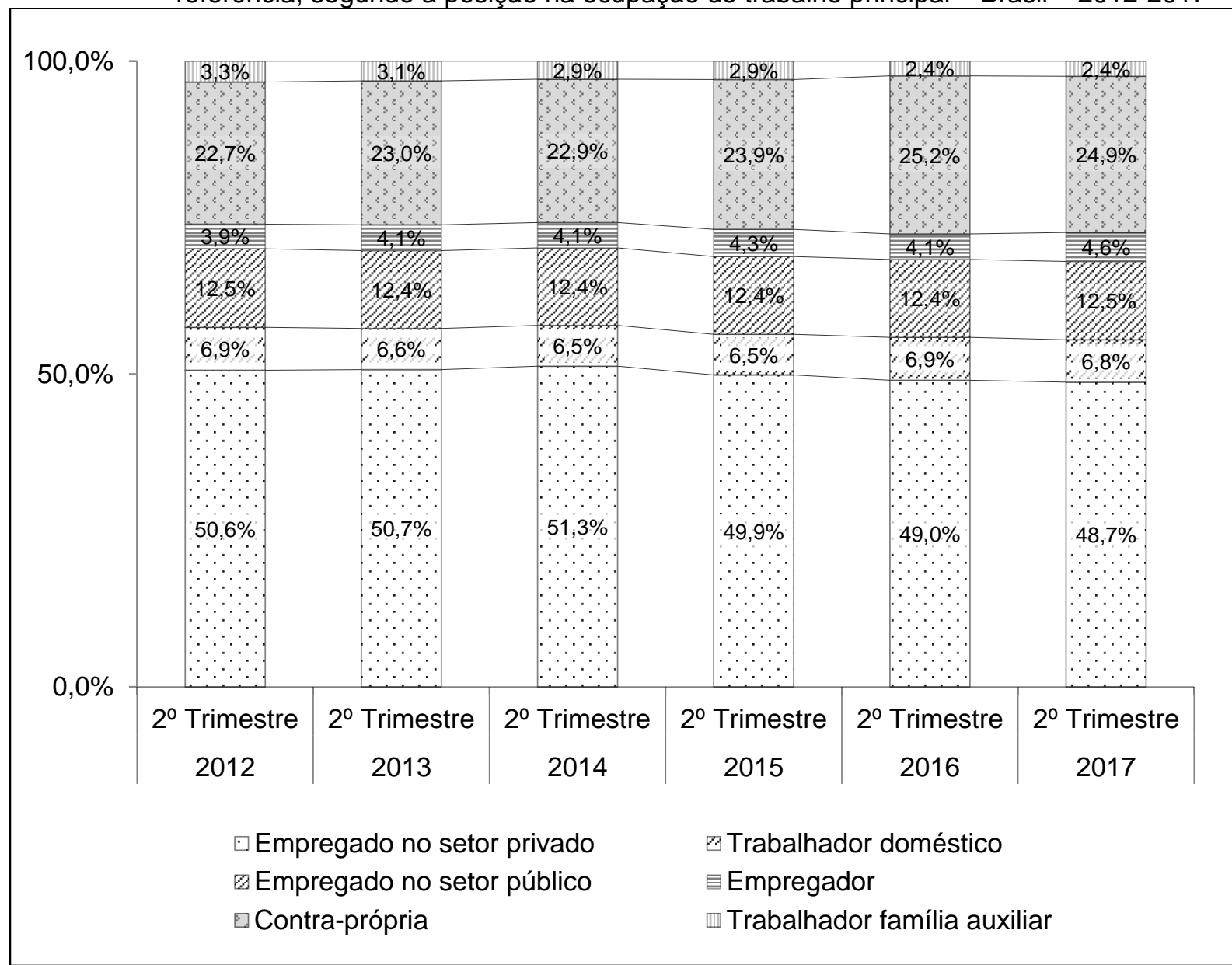

Fonte: adaptado IBGE (2017).

Outro dado consistente é a evolução dos estabelecimentos no país. O Gráfico 6 revela a configuração e evolução desde 2012 da estrutura dos estabelecimentos do Brasil, segundo o setor de atividade. Em um total de 8.312 milhões de estabelecimentos declarantes, o setor de serviços é o que demonstrou maior crescimento nos últimos anos, chegando a marca de 3.577 milhões de 
estabelecimentos com ou sem empregados, ou seja, o setor teve a maior representatividade entre os demais, inclusive ultrapassando o setor de comércio, o segundo com o maior número.

Gráfico 6 - Total de estabelecimentos sem vínculos e com vínculos por setor de atividade

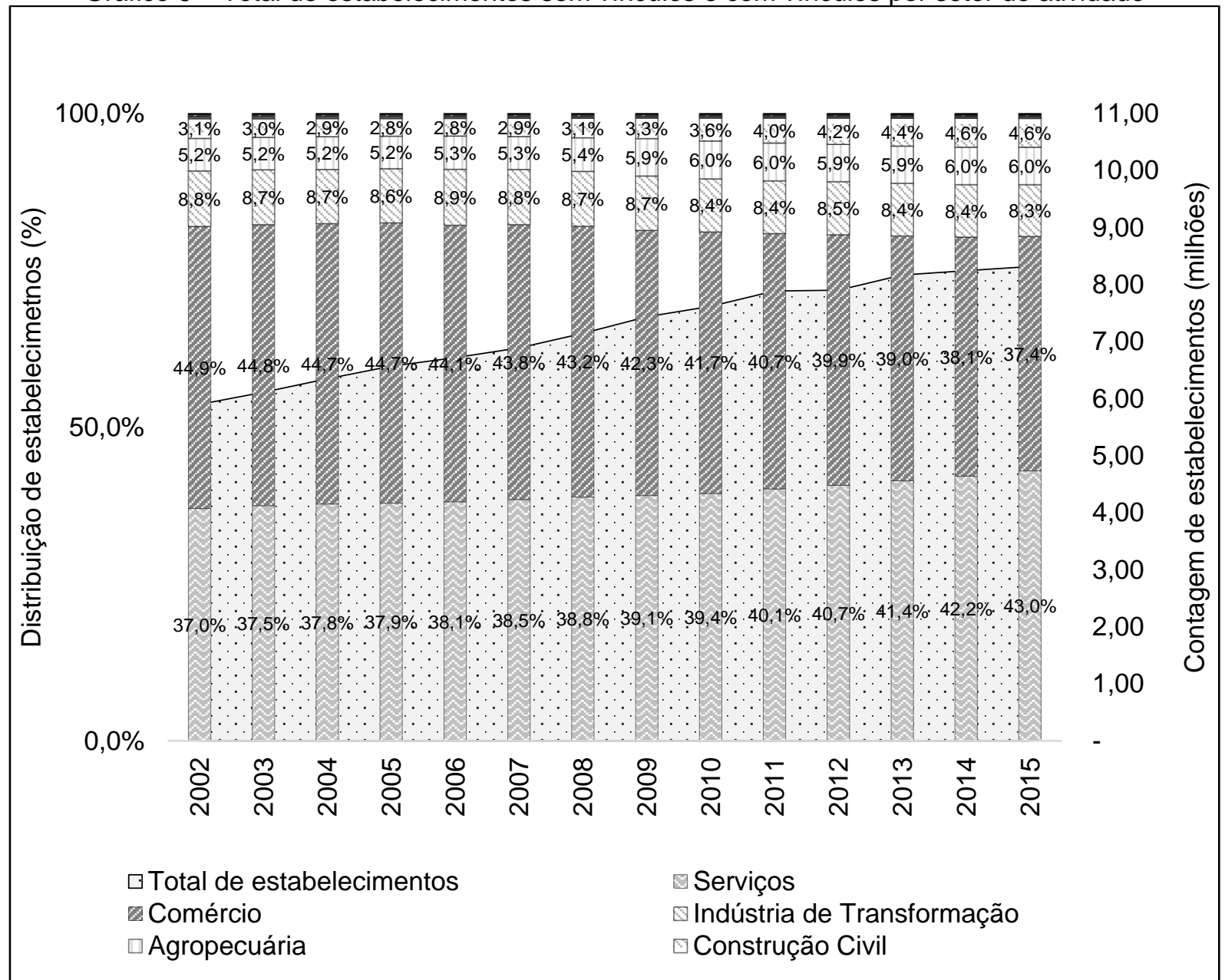

Fonte: adaptado de RAIS (2016).

Nota: atividades com menos de $1 \%$ de representatividade estão sem legenda no gráfico.

No Gráfico 7 é possível visualizar que, ao longo do tempo, tem ocorrido o crescimento da alocação de mão-de-obra nos setores com atividades ligadas a área de prestação de serviço. Em contrapartida, setores como indústria, agricultura, construção vem passando por declínio ou instabilidade, demonstrando assim a forte tendência no crescimento da área de serviços e o retraimento das áreas ligadas a produção. 
Gráfico 7 - Distribuição das pessoas de 14 anos ou mais, ocupadas na semana de referência, por grupamentos de atividade econômica, Brasil - $2^{\circ}$ trimestre de 2012-2017

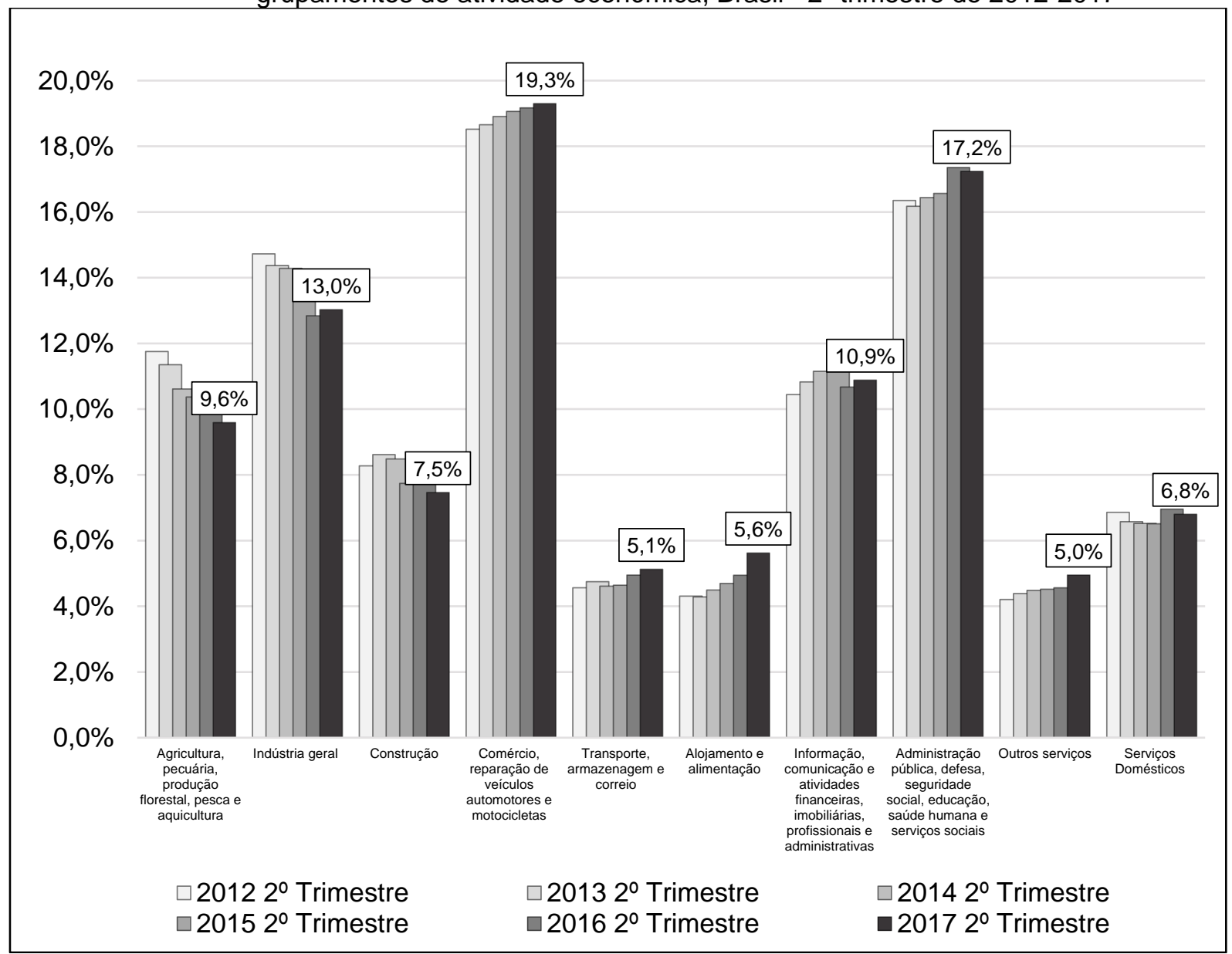

Fonte: adaptado IBGE (2017).

Em suma, enfrentaremos no futuro uma crescente queda na natalidade e um aumento da idade média de nossa população. Ao longo prazo, tal configuração acarretará em mudanças no mercado de trabalho e já é possível verificar ciclos de carreira cada vez mais rápidos e uma longevidade crescente da população. Isso inclusive poderá descontinuar processos dentro da GP que são funcionais na atualidade e poderão passar a obsolescência ao amanhã (DUTRA, 2017).

\subsection{O PAPEL DA GESTÃO DE PESSOAS NAS ORGANIZAÇÕES}

Todos os processos de GP são igualmente importantes e atuam como vasos comunicantes entre si. O importante é tratá-los como uma totalidade. Quando um deles falha, consequentemente sobrecarrega os demais. O segredo está no tratamento sistêmico e integrado da função de GP. O que interessa é o todo e não somente cada uma de suas partes. A rede, ou seja, a conectibilidade é o que faz a diferença. (CHIAVENATO, 2014, p. 14). 
No contexto atual é difícil manter um consenso frente à nomenclatura que melhor represente a real demarcação dos processos ligados a administração de $\mathrm{RH}$, foram tantas alterações que acometeram aos termos, que, determinar uma única terminologia capaz de representar seu momento atual torna-se uma tarefa extremamente difícil, a velocidade das mudanças tem impactado diretamente no consenso teórico sobre sua definição, porém como conceito recente a terminologia Gestão de Pessoas tem maior destaque. (CHIAVENATO, 2014).

Apesar de tantas alterações, por conta de seu histórico de caráter consultivo ou ainda estritamente operacional, a área ainda carrega consigo uma fama de papel secundário (DESSLER, 2014). Tradicionalmente as organizações tratam as pessoas como um recurso administrativo na organização da produção, porém a pressão externa para alterar tais prática tem feito sentido e forçado a revisão na maneira de gerir pessoas (DUTRA, 2017).

Em suma, a história de área de GP é recente, sua origem começa basicamente após a Revolução Industrial, perpassando até os dias atuais. Na atualidade tudo que está vinculado ao conceito evolui com força máxima, principalmente em razão dos tempos de altos níveis de dinamismo e competitividade presentes no contexto das organizações. Ao longo do tempo isso acarretou em uma onda de mudanças que perduraram marchando em conjunto com a realidade do desenvolvimento tecnológico, econômico, cultural, legal, político, demográfico e ecológico da sociedade. Isso tem gerado os novos papéis da GP, conforme retratados no Quadro 1 (CHIAVENATO, 2014):

Quadro 1 - Novos papéis da Gestão de Pessoas

\begin{tabular}{|l|l|}
\hline \multicolumn{1}{|c|}{ De } & \multicolumn{1}{c|}{ Para } \\
\hline Operacional e burocrático & Estratégico \\
\hline Policiamento e controle & Parceira e compromisso \\
\hline Curto prazo e imediatismo & Longo prazo \\
\hline Administrativo & Consultivo \\
\hline Foca na função & Foco no negócio \\
\hline Foco interno e introvertido & Foco no externo e no cliente \\
\hline Reativo e solucionado de problemas & Proativo e preventivo \\
\hline
\end{tabular}




\begin{tabular}{|l|l|}
\hline Foca na atividade e nos meios & Foco nos resultados e nos fins \\
\hline
\end{tabular}

Fonte: adaptado de Chiavenato (p. 41, 2014)

Segundo Dutra (2017), na atualidade, a caracterização da GP permeia a conciliação entre as expectativas da organização e das pessoas para que 0 atendimento mútuo de tais anseios possam satisfazer as partes ao longo do tempo. No momento atual, cabe as organizações fornecer as pessoas o estímulo para entregar resultados e, além disso, atender suas expectativas. Em contrapartida, as pessoas precisam manter um papel participativo, compartilhando e negociando seu projeto de desenvolvimento pessoal. Para que tudo funcione, é indispensável que os sujeitos tenham consciência de sua capacidade de contribuição e os limites concretos da organização em atender suas expectativas.

Para Lucena (2014) a modernidade tem feito o trabalhador evoluir de um simples "meio de produção" para um "gerador de produção" e cita três horizontes ou premissas que decodificam esse momento. A primeira trata de que a força propulsora das organizações é a mente humana; a segunda recorre que para a expressão humana tenha pleno exercício, é preciso um conjunto de valores e atributos que formem uma ambiência organizacional; a terceira diz respeito aos desafios das organizações da atualidade em construir esse ambiente organizacional favorável, o qual será capaz de promover o desenvolvimento humano e profissional, em conjunto com o sucesso da organização.

Ao refinar tais conceitos modernos, é possível perceber o aumento da importância da carreira subjetiva, diante da desvalorização da carreira objetiva. Isso remete que as pessoas irão decidir suas carreiras pautadas em valores, famílias e compromissos sociais e reduzir o valor sob aspectos de salários e status profissional (FERNANDES, 2013). Porém, ainda é comum para as organizações se caracterizarem por interesses econômicos, enquanto a GP avança com outras preocupações, que inclusive não vão de encontro com os interesses do mercado. Estamos em meio a um regaste da subjetividade no trabalho, uma busca por reaproximar as práticas manuais e a subjetividade dos indivíduos no ambiente organizacional - as quais foram distanciadas em função do desenvolvimento histórico (LOCH; CORREA, 2004).

Conforme definido por Chiavenato (2014) a Figura 1 demonstra as principais características de cada processo de GP. Os quais estão divididos em: a) processos 
de agregar pessoas: utilizados no recrutamento e seleção de pessoal; b) processos de aplicar pessoas: utilizados para determinar as atividades que as pessoas irão executar, bem como acompanhar seu desempenho; c) processos de recompensar pessoas: utilizados para satisfazer e incentivar as pessoas, através de recompensas, remuneração e benefícios; d) processos de desenvolver pessoas: utilizados no desenvolvimento dos profissionais, através do treinamento, gestão do conhecimento e competências, além de programas de desenvolvimento de carreira; e) processos de manter pessoas: utilizados para criar um ambiente positivo para as pessoas, as quais envolve questões ambientais e psicológicas, clima, higiene, segurança, qualidade de vida e relações sindicais; f) processos de monitorar pessoas: utilizados para controlar as atividades e resultados das pessoas, através dos sistemas de informações gerenciais.

Figura 1 - Os processos básicos de Gestão de Pessoas

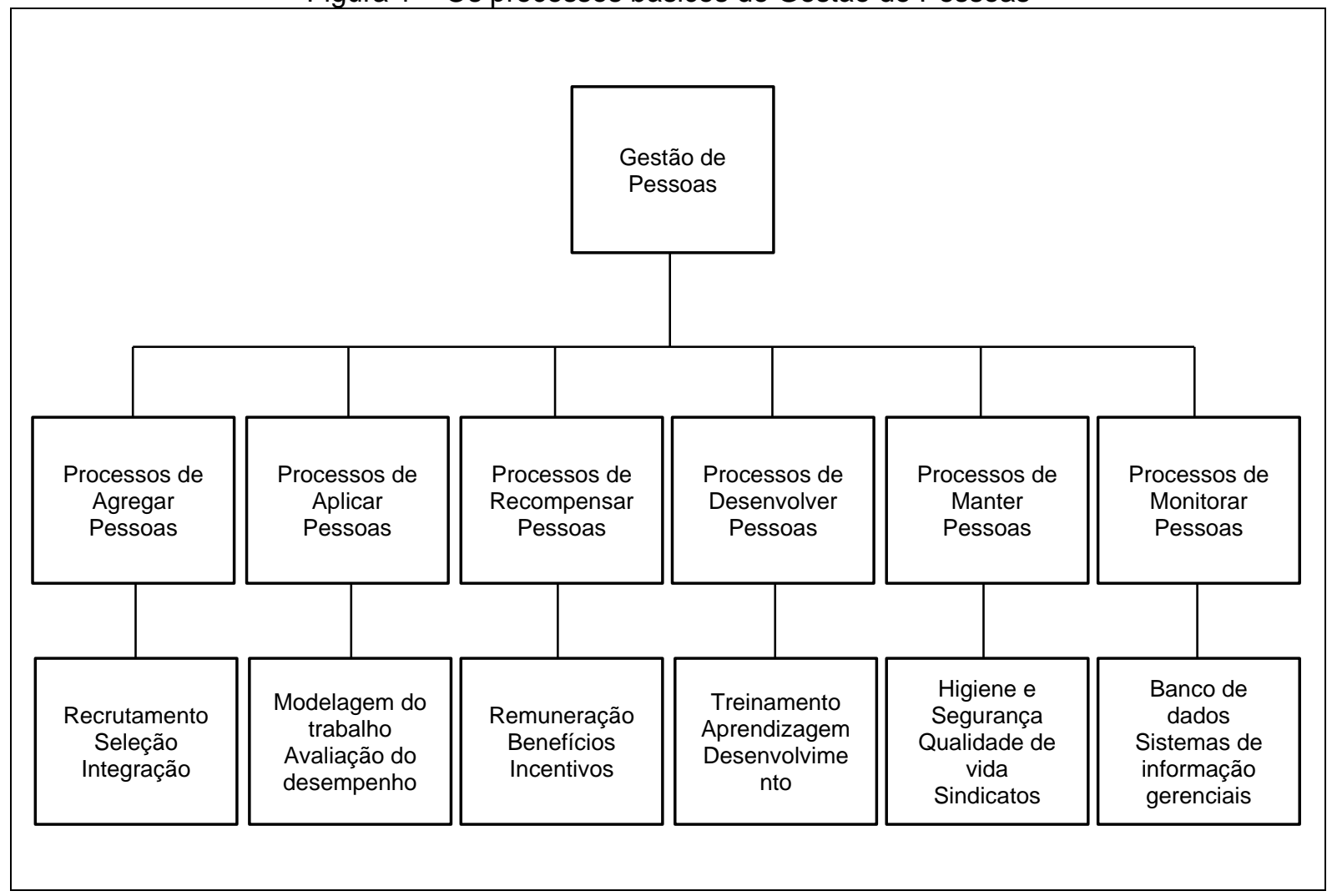

Fonte: adaptado de Chiavenato (2014, p. 14)

A GP tem concentrado sua evolução em aspectos de controle, esperando das pessoas uma correspondência passiva e submissa. Apesar de o discurso da atualidade ser outro, com foco na autonomia e empreendedorismo - aos poucos esse 
distanciamento irá ser reduzido e cada vez mais exigido a efetivação das práticas da GP (FERNANDES, 2013).

Em uma pesquisa exploratória, descritiva, realizada por Oliveira (2013) em hospitais universitários, com o objetivo de identificar fatores e novas tendências de GP, conforme a percepção dos gestores da área da saúde. Os resultados mostraram tendências de que a GP irá sofrer mudanças significativas nos próximos 10 anos $(86,7 \%)$ e que estarão ligadas as práticas e instrumentos de gestão (50\%). Existe ainda a tendência de mudança do ambiente, frente à busca pela qualidade dos processos e produtos, o questionamento do papel da instituição, da cidadania e do direito do consumidor, além das alterações na tecnologia, aplicada aos processos e organizacionais. Foi ainda, evidenciado a parcialidade da introdução de conceitos de alta relevância para GP, o empowerment ${ }^{1}$ de forma coerente com o negócio, comprometimento da força de trabalho com os objetivos organizacionais, educação corporativa e autodesenvolvimento.

\title{
2.5 AS ORGANIZAÇÕES SOCIAIS E FUTURO DAS RELAÇÕES DE
} EMPREGO EM SAÚDE

\begin{abstract}
Por que a competição não está funcionando no sistema de saúde? Por que o valor aos pacientes não é mais alto e não melhora com rapidez? A razão não é falta de competição, mas o tipo errado de competição. A competição acontece nos níveis errados e nas coisas erradas. Gravitou para uma competição de soma zero, na qual os ganhos de um participante do sistema são auferidos a expensas dos outros. Os participantes competem na transferência de custos, uns para os outros, no acúmulo de poder de barganha e na limitação de serviços. Esse tipo de competição não gera valor para os pacientes, mas corrói a qualidade, nutre a ineficiência, cria capacidade excessiva e eleva os custos administrativos, entre outros efeitos abomináveis. (PORTER, 2014, p. 21)
\end{abstract}

Por último, é preciso compreender as principais características das Organizações Sociais (OS) e das relações de emprego em saúde na atualidade. Além de levantar as especificidades relacionadas ao ambiente de trabalho da área da saúde, o qual faz plano de fundo ao estudo.

As OS fazem parte de uma proposta do governo para gestão de serviços públicos, inclusive o setor da saúde no Brasil. Qualificadas através da medida

\footnotetext{
1 Expressão utilizada para expressar o empoderamento dos trabalhores, através da delegação de responsabilidade e uma maior autonomia de descisão.
} 
provisória ํㅜ 1.591/1997 (BRASIL, 1997) e posteriormente sancionada Lei ํo de 9.637 de 15/05/1998 (BRASIL, 1998a), que dispõe sobre a qualificação dessas entidades, conforme descrito abaixo:

Art. 1. O Poder Executivo poderá qualificar como organizações sociais pessoas jurídicas de direito privado, sem fins lucrativos, cujas atividades sejam dirigidas ao ensino, à pesquisa científica, ao desenvolvimento tecnológico, à proteção e preservação do meio ambiente, à cultura e à saúde, atendidos aos requisitos previstos nesta Lei. (BRASIL, 1998a).

De acordo com Melo e Tanaka (2001), em meados dos anos 80 ocorreu uma crise do Estado em toda América Latina. O fato acabou colocando em descrédito a capacidade administrativa e a configuração da estrutura vinculada a esfera pública, fronte aos problemas econômicos e sociais. Diante da situação, emergiu a necessidade de reforma do Estado, caracterizada principalmente pela crescente crise fiscal, por aspectos protecionistas da econômica e pela experiência de um Estado arcaico e ineficiente. Ao longo do desenrolar da crise, medidas foram tomadas, a fim de reformar sua estrutura, com destaque para um novo modelo de administração pública, baseado em conceitos atuais da administração.

\begin{abstract}
Transferir para o setor público não-estatal estes serviços, através de um programa de "publicização", transformando as atuais fundações públicas em organizações sociais, ou seja, em entidades de direito privado, sem fins lucrativos, que tenham autorização específica do Poder Legislativo para celebrar contrato de gestão com o Poder Executivo e assim ter direito a dotação orçamentária. (BRASIL, 1995, p. 58).
\end{abstract}

No Brasil não foi diferente, o Plano Diretor da Reforma do Aparelho de Estado de 1995 emergiu com a proposta de reconstruir o Aparelho do Estado, a sua construção foi embasada na evolução da administração pública, que na época era concebida em favor de três modelos: a administração pública patrimonialista, a burocrática e a gerencial. As três formas evoluíram sucessivamente, respeitando as mudanças da sociedade e, na medida em que progrediram, não abandonaram por completo o modelo anterior. Vale ressaltar que, por último, a administração pública gerencial surgiu no século XX, em forma de resposta ao desenvolvimento de atividades econômicas e sociais por parte do Estado e pela evolução tecnológica e à globalização da economia mundial. Com isso, a reforma passou a ser orientada pelos valores de eficiência e qualidade na prestação de serviços públicos e através da evolução da cultural gerencial das organizações. Por fim, a reforma do Estado foi 
praticada com o objetivo de aumentar sua capacidade de administrar serviços, ao distribuir a produção de bens e serviços para o mercado da iniciativa privada, além de transferir, a responsabilidade e ações de caráter regional para os estados e municípios (BRASIL, 1995).

A pressão econômica e as políticas nacionais e internacionais, fizeram com que o governo partisse em busca de alternativas para diminuir o Estado e para aumentar sua flexibilidade, frente a administração dos serviços. Aos poucos, o distanciamento entre o público e o privado foi deixando de existir e, foram criadas novas possibilidades no modelo de gestão pública, através de emendas constitucionais em favor da flexibilização do setor (MARTINS; MOLINARO, 2013).

Em meio à crise da área hospitalar, que provou a ineficiência do modelo da administração pública na área da saúde, acarretou na mudança do posicionamento das entidades públicas para uma atuação intermediária, passando atuar principalmente no gerenciamento dos processos e fornecimento dos meios para execução dos serviços. Dessa forma, cada vez mais, a esfera pública tem se afastado da linha de frente da produção de serviços (IBANEZ; VECINA NETO, 2007).

As OS são uma nova forma de parceria entre o setor público e privado, com a valorização do chamado terceiro setor - serviços de interesse público que não necessitam ser prestados pelos órgãos e entidades governamentais. Para sua validade é necessário atender os requisitos previstos na Lei federal 9.637, de 18.5.98. Em suma, tal molde de organização é composta por pessoas jurídicas de Direito Privado, sem fins lucrativos, cujas atividades estatutárias são dirigidas ao ensino, à pesquisa científica, ao desenvolvimento tecnológico, à proteção e preservação do meio ambiente, à cultura e à saúde. (MEIRELLES, 2016)

Existem diferentes tipos de personalidades jurídicas na administração pública brasileira. As OS ganharam destaque na área da saúde e seu resultado tem sido considerado como uma opção valiosa. O Estado demonstrou ter aprendido a controlar a esfera privada, através de um contrato de gestão recheado com objetivos e metas, capazes de planejar, organizar, liderar e controlar suas atividades. Essas entidades são personalidades jurídicas de direito privado, uma associação sem fins lucrativos ou fundação de direito privado qualificada, que exerce atividade pública descentralizada e regidas pela Lei 9637/98, que no caso, desobriga sua submissão às normas do direito público. Outras características dessa modalidade de regime 
jurídico são bem distintas dos demais, como: ter firmado suas obrigações em um contrato de gestão, regime de trabalho baseado na Consolidação das Leis do Trabalho (CLT) sem concurso público e ter privilégios tributários. (IBANEZ; VECINA NETO, 2007).

Foram implementadas duas vertentes para lidar com a questão da saúde: a transferência de atividade do setor público para o privado e a descentralização o setor público não-estatal. Por fim, a criação das OS no Brasil permitiu mudanças na estrutura da administração pública, bem como no Sistema Único de Saúde (SUS) que conta com um modelo versátil e, contempla, por parte do setor público, a possibilidade de comprar serviços do setor privado. Por essas e outras razões, o SUS constantemente é responsabilizado pela segmentação e da falta de equidade no Brasil, com duras críticas ao setor público estatal e a sua ineficácia na gestão. Essa transferência de serviços da esfera pública estadual para as OS é um processo voluntário, com destaque para serviços prioritários, como: hospitais, universidades, escolas técnicas, centros de pesquisa, bibliotecas e museus (MELO; TANAKA, 2001).

O Conselho Federal de Contabilidade (2012) aprovou a interpretação acerca das entidades sem finalidade de lucro. Que pode ser constituída através de uma fundação de direito privado, associação, organização social, religiosa, partido político e entidade sindical. Dentre suas atividades, podem executar assistencial social, saúde, educação, técnico-científica, esportiva, religiosa, política, cultural, beneficente, social, entre outras atividades. Com o objetivo de administrar pessoas, coisas, fatos, interesses acerca de um patrimônio com objetivo comum ou causa comunitária.

Apesar dos aspectos positivos destacados anteriormente, Porter (2014), anuncia que no contexto atual e, em um mercado normal, a competição é fonte de melhoria continua em qualidade e custos. Contudo, na área da saúde essa sistemática tem falhado, seu resultado cabe a uma competição disfuncional, pautada em más escolhas estratégicas, organizacionais e regulamentares. $\mathrm{O}$ foco dos sistemas de saúde recai sob aspectos de custo e na luta de quem será responsabilizado pelo custo, o que gera uma superprodução e o diminuição no valor gasto por paciente. Porém, isso tudo gera estratégias e práticas extremamente desalinhas com o que é necessário para agregar valor para o paciente, o que traria de fato uma evolução considerável a esses sistemas. 
Conforme descrito no Quadro 2, a política de redução do Estado trouxe consigo vários impactos, como: a privatização e terceirização de serviços, o limite de gasto de pessoal e a não realização de concurso público. Isso tudo levou ao crescimento do mercado informal de trabalho em saúde, que acarretou em prejuízo ao trabalhador, pela perda de direitos sociais conquistados ao longo dos anos, em razão da flexibilização dos modelos de contratação (MARTINS; MOLINARO, 2013).

Quadro 2 - Variáveis Padrão do Modelo de Direito do Trabalho na Área Social aplicado às relações de trabalho no Setor Público de Saúde no Brasil.

\begin{tabular}{|c|c|c|}
\hline $\begin{array}{c}\text { Variável padrão do } \\
\text { Modelo de Direito do } \\
\text { Trabalho na Área } \\
\text { Social }\end{array}$ & \multicolumn{2}{|c|}{ Tensões na relação trabalho-emprego no âmbito dos serviços } \\
públicos de saúde no Brasil
\end{tabular}




\begin{tabular}{|c|c|c|}
\hline \multirow{3}{*}{ Representação } & $\begin{array}{c}\text { Proteção da voz coletiva no } \\
\text { mercado de trabalho, proteção do } \\
\text { reconhecimento como parceiro } \\
\text { social, proteção do diálogo social } \\
\text { através de sindicatos livres e } \\
\text { independentes e associações de } \\
\text { empregadores, direitos à greve, } \\
\text { direitos de informação, participação } \\
\text { e consulta. }\end{array}$ & $\begin{array}{c}\text { Não reconhecimento dos direitos } \\
\text { sindicais e de participação; não } \\
\text { reconhecimento do direito à greve } \\
\text { tanto dos vínculos estatais, } \\
\text { temporários e terceirizados. }\end{array}$ \\
\hline
\end{tabular}

Fonte: MARTINS; MOLINARO, 2013, p. 1675.

As novas configurações no campo de trabalho na saúde, segundo Martins e Molinaro (2013), deve ser pensada em razão de equacionar aspectos, como: acesso aos postos de trabalho, ambiente e condições de trabalho, proteção social, remuneração, qualificação, participação política e acesso à tecnologia.

Estamos em um momento de crescimento desordenado do setor terciário (comércio e serviços), com aumento de desocupação e desemprego, além do aumento da informalidade nas relações de trabalho. Contudo, no setor da saúde, a incorporação de novas tecnologias dependerá ainda da mão-de-obra, o que revive a necessidade da formação contínua dos profissionais da saúde. (MARTINS; MOLINARO, 2013).

Dessa forma, é possível evidenciar que existe um conflito frente às obrigações dos empregados e empregadores, com uma infinidade de dúvidas e conflitos presentes entre o cotidiano do profissional da saúde (FREITAS; FUGULIN; FERNANDES, 2006). 
3 METODOLOGIA 


\section{METODOLOGIA}

\subsection{TIPO DE ESTUDO}

Estudo de natureza básica e retrospectiva, exploratória, sem intervenção, com a finalidade de desenvolver, esclarecer e modificar conceitos e ideias, frente às hipóteses estabelecidas, através de uma abordagem quantitativa e qualitativa (GIL, 2008).

Em suma, apesar da proximidade do fenômeno observado com o método dialético, optou-se pelo método hipotético-dedutivo para compreensão, a principal justificatiova cabe a necessidade de delimitar a análise dos fatos e o grande interesse prático do estudo. Outros fatores é de que o estudo esteve apoiado sobre o ideais empírico e lógico, além da falta de conhecimento disponível para explicar o problema levantado, conforme os objetivos da pesquisa. Por fim, o estudo também apresenta afinidade tanto com o método quantitativo e qualitativo.

Portanto, através das hipóteses formuladas, foram feitas deduções das consequências observadas e a tentativa de falseamento delas. Caso não exista evidência para falsear alguma das hipóteses, a mesma permanecerá comprovada provisoriamente (GIL, 2008). Para proporcionar maior rigor e precisão ao estudo, em vista de seu caráter social, foram empregados métodos de procedimento descritos adiante.

\subsection{LOCAL DO ESTUDO}

A pesquisa foi realizada no Hospital Estadual Américo Brasilense (HEAB), o qual, a partir de agosto de 2010, tem sido administrado pela Fundação de Apoio ao Ensino, Pesquisa e Assistência do Hospital das Clínicas da Faculdade de Medicina de Ribeirão Preto da Universidade de São Paulo (FAEPA), a qual é qualificada como OS. Na mesma estrutura física e administrativa funciona o Ambulatório Médico de Especialidades (AME) de Américo Brasiliense, os quais, juntos, compõem o complexo assistencial totalmente voltado para Sistema Único de Saúde (SUS).

A escolha da instituição deu-se em razão da facilidade de acesso às fontes, além de seu vínculo administrativo com o Hospital das Clínicas da Faculdade de Medicina de Ribeirão Preto (HC-FMRP) e por proporcionar as atividades de 
assistência, pesquisa e ensino. O complexo também desempenha e conta com atividades nos principais subsistemas da área GP, com ações já implantadas, consagradas e outras em desenvolvimento, as quais são essenciais para 0 desenvolvimento do estudo.

Outro ponto relevante é de que a instituição tem o selo nível de "excelência" da Organização Nacional de Acreditação (ONA) e diversos outros prêmios. Isso demonstra seu objetivo e estilo de gestão voltado em oferecer um serviço de qualidade, preceitos que vão de encontro com as exigências sociais e econômicas encontradas na pesquisa bibliográfica.

As vantagens advindas do processo de "acreditação" estão relacionadas com a melhoria do gerenciamento, bem como na centralização e na segurança do usuário. Como desvantagem, existe a dificuldade de se estabelecer a cultura baseada na qualidade (OLIVEIRA; MATSUDA, 2016). Sob o aspecto da GP, é de extrema importância que ocorra o envolvimento entre gestores e a própria GP para o processo de acreditação hospitalar (MARQUES; SILVA, 2007).

Figura 2 - Fotografia aérea do Hospital Estadual Américo Brasiliense

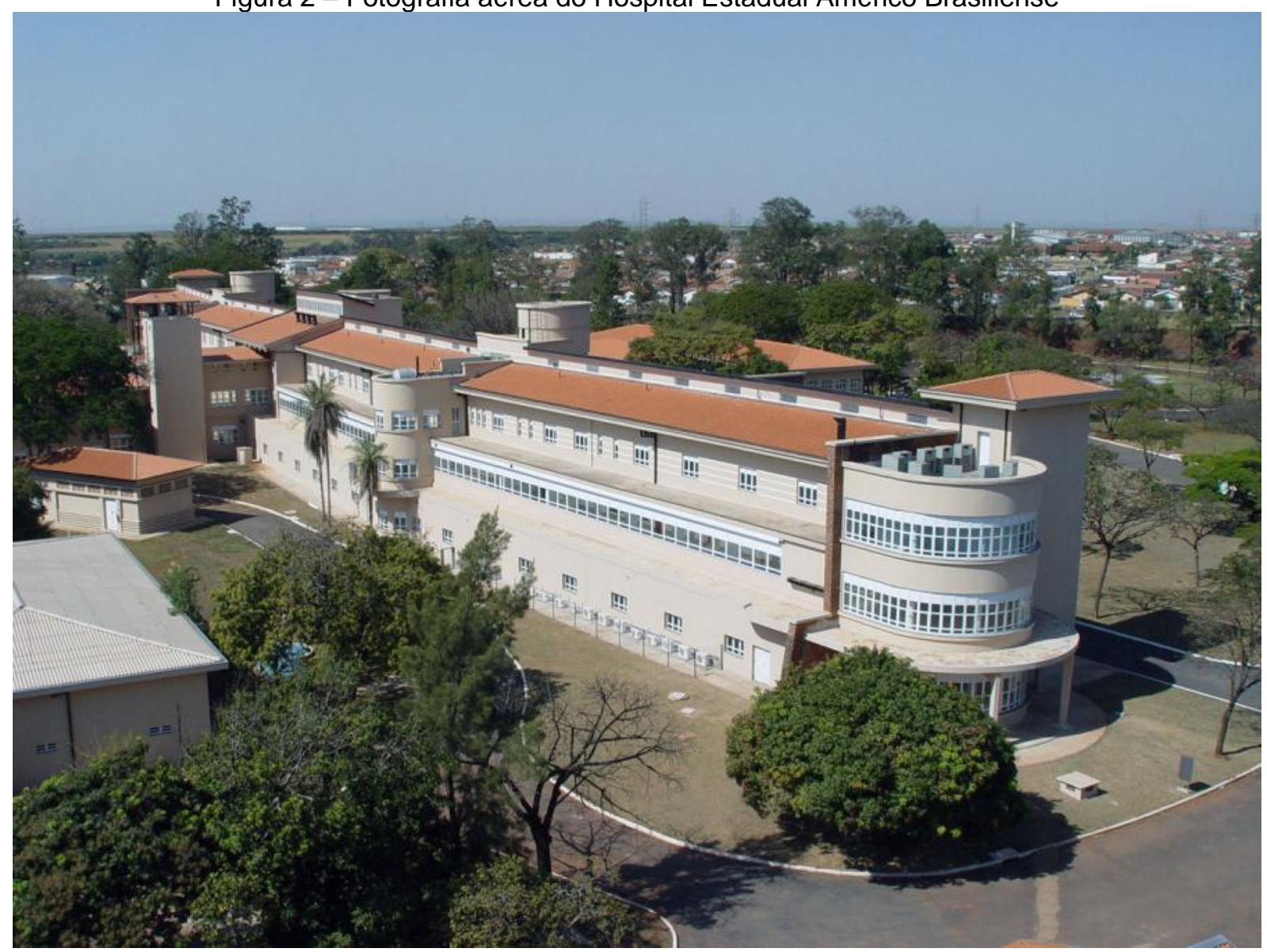

Fonte: HEAB (2016). 


\subsection{AMOSTRA}

\subsubsection{Critérios de inclusão}

Foram incluídas na amostra todas as petições iniciais, no âmbito trabalhista, recebidas pela instituição de agosto de 2010 até dezembro de 2018 de trabalhadores, que contemplasse todas a funções, com vínculo empregatício direto e indireto.

\subsubsection{Critérios de exclusão}

Foram excluídas da amostra as petições iniciais vinculadas a organizações que antecederam a administração da FAEPA - anterior a agosto de 2010, processos de outras áreas que não seja de cunho trabalhista ou que tenham alguma forma de sigilo, conforme garantido no art. 93, inciso IX, da Constituição da República e no art. 155 do Código de Processo Civil.

\subsection{COLETAS DE DADOS}

Para coleta dos dados foram utilizadas as pesquisas documental e bibliográfica, ambas têm características muito próximas, sendo a principal diferença entres natureza da fonte de dados. Enquanto pela pesquisa bibliográfica buscou-se levantar a contribuição de diversos autores, em: livros, revistas, ou meio eletrônico. A pesquisa documental teve por objetivo realizar o tratamento analítico dos materiais que não passaram por nenhum tipo de análise e que estariam disponíveis sob os mais diversos formatos, como: fichas, mapas, formulários, cadernetas, documentos, etc. Os passos para aplicação das duas foram os mesmos, porém é necessário considerar que a fonte da pesquisa bibliográfica é constituída por material impresso e a pesquisa documental, as fontes são diversificadas e dispersas (GIL, 2002). Cada parte da pesquisa teve sua abordagem, conforme abaixo:

a) Pesquisa bibliográfica: levantar o referencial teórico em fontes e materiais já elaborados, por meios escritos e eletrônicos, publicado em livros, artigos científicos, páginas de web sites. 
b) Pesquisa documental: analisar as petições iniciais, ajuizadas entre os 08/2010 até 12/2018 em meio digital ou físico. Além de relatórios emitidos pelo sistema de informação da instituição.

Dessa forma, os dados documentais foram levantados através da análise de todas as petições iniciais arquivadas nos setores responsáveis, a fim de extrair as informações necessárias para análise estatística descritiva e inferencial. Para interpretação, uma planilha foi construída no programa Microsoft Excel, a qual compõe todo banco de dados do estudo.

\subsection{ANÁLISE E INTERPRETAÇÃO DOS DADOS}

O estudo tem caráter exploratório, baseado na observação de uma única instituição, a fim de proporcionar a representatividade de outros casos semelhantes a mesma. Além de garantir a parametrização fidedigna, frente à realidade pesquisada $\mathrm{e}$ em conformidade com o objetivo de avaliar os acontecimentos retrospectivos que influenciaram diretamente no ajuizamento de ações trabalhistas. Para corresponder aos objetivos e as hipóteses propostas no trabalho, o método para análise foi construído a partir da combinação dos enfoques quantitativos e qualitativos.

Foram aplicados os procedimentos da estatística descritiva e inferencial, de acordo com o Quadro 3, a fim de caracterizar o que é típico ao grupo e, assim, identificar a variabilidade nos dados e verificar como é sua distribuição em relação as variáveis (GIL, 2002). Isso compõe a base para a correlação dos dados e garantiu uma maior probabilidade de acerto frente à testagem das hipóteses.

Quadro 3 - Análise e interpretação dos dados

\begin{tabular}{|c|c|c|c|c|c|}
\hline Objetivo & Método & Variável & Análise & Estatística & Exposição \\
\hline $\begin{array}{c}\text { Levantar o } \\
\text { histórico de } \\
\text { ajuizamento de } \\
\text { reclamações } \\
\text { trabalhistas }\end{array}$ & $\begin{array}{c}\text { Contagem versus } \\
\text { data de } \\
\text { distribuição }\end{array}$ & $\begin{array}{c}\text { Aleatória } \\
\text { discreta }\end{array}$ & Quantitativa & Descritiva & $\begin{array}{c}\text { Gráfico de } \\
\text { barras }\end{array}$ \\
\hline $\begin{array}{c}\text { Levantar o tipo de } \\
\text { rito }\end{array}$ & $\begin{array}{c}\text { Contagem de rito: } \\
\text { ordinário, } \\
\text { sumaríssimo e } \\
\text { sumário versus } \\
\text { data de } \\
\text { distribuição }\end{array}$ & $\begin{array}{c}\text { Aleatória } \\
\text { discreta }\end{array}$ & Quantitativa & Descritiva & $\begin{array}{c}\text { Gráfico de } \\
\text { barras }\end{array}$ \\
\hline
\end{tabular}




\begin{tabular}{|c|c|c|c|c|c|}
\hline Direito pleiteado & $\begin{array}{c}\text { Contagem dos } \\
\text { assuntos contidos } \\
\text { nas reclamações }\end{array}$ & $\begin{array}{c}\text { Aleatória } \\
\text { discreta }\end{array}$ & Quantitativa & Descritiva & Tabela \\
\hline $\begin{array}{c}\text { Compreender o } \\
\text { comportamento da } \\
\text { dos reclamantes }\end{array}$ & $\begin{array}{c}\text { Análise de } \\
\text { Cluster }\end{array}$ & $\begin{array}{c}\text { Aleatória } \\
\text { discreta }\end{array}$ & Quantitativa & Inferencial & Dendograma \\
\hline $\begin{array}{c}\text { Categorizar o } \\
\text { direito pleiteado de } \\
\text { acordo com os } \\
\text { processos da } \\
\text { Gestão de } \\
\text { Pessoas }\end{array}$ & $\begin{array}{c}\text { Discurso do } \\
\text { sujeito coletivo }\end{array}$ & Nominal & Qualitativa & Descritiva & Tabela \\
\hline
\end{tabular}

Fonte: elaborado pelo autor, com base nos objetivos do estudo.

O objetivo da análise de agrupamentos é agregar objetos com base nas características que possuem, diferente da análise fatorial que tem como objetivo analisar variáveis. Esse tipo de análise é utilizado quando existe um grande número de observações que não tenham significado, ao menos que possam ser classificadas. A redução pode ser feita em uma população inteira ou em uma amostra, formando subgrupos específicos. Isso torna possível compreender o comportamento da população através a identificação de seus principais grupos, com a perda mínima de informações. Por fim, a análise é útil para formular hipóteses relativas à natureza dos dados ou examinar outra previamente estabelecidas (HAIR, 2009)

O método do Discurso do Sujeito Coletivo (DSC) foi empregado para análise das petições iniciais, com o objetivo de abstrair e classificar os assuntos de acordo com cada estratégia de GP. O conteúdo foi sintetizado em categorias, conforme as ideias centrais com conteúdo e argumento semelhantes encontradas ao longo das reclamações analisadas. Isso, por fim, compôs um depoimento síntese de cada categoria, redigido na primeira pessoa do singular (LEFEVRE; LEFEVRE, 2014).

A DSC concretiza, através da aplicação das etapas de seu método a abstração de experiências e vivências coletivas comuns. Em suma, ocorre a construção através de um movimento dialético, a descrição sistemática da realidade observada, o que possibilita a observação e produção de conhecimento científico com transparência e reprodutibilidade (LEFEVRE, 2017).

Segundo Lefevre (2017) esse método é uma das inúmeras possibilidades de se encontrar e demonstrar representações sociais. Ao curso de seu desenvolvimento existem algumas etapas para sua aplicação: 
a) Etapa 1: obtenção de depoimentos: no caso do estudo serão utilizadas as petições iniciais dos processos trabalhistas;

b) Etapa 2: redução do discurso: as petições serão analisadas individualmente, a fim de captar seu conteúdo essencial e determinar as Expressões Chaves;

c) Etapa 3: busca do (s) sentido (s): determinado as expressões chaves, será verificado o posicionamento (s) em cada petição frente ao problema, identificando assim, sua ideia central;

d) Etapa 4: categorização: determinado as expressões chaves, será verificado o posicionamento (s) em cada petição frente ao problema, identificando assim, sua ideia central;

e) Etapa 5: discursos do sujeito coletivo: neste ponto são reunidos, equiparando as expressões chaves e ideia central apresentam sentido semelhante. $O$ discurso é redigido na primeira pessoa do singular, sua composição trará o conjunto dos conteúdos agrupados em uma categoria. 


\section{RESULTADOS}

\subsection{RESULTADOS QUANTITATIVOS}

Ao todo, o estudo levantou o efetivo de 92 processos no período de 2010 até 2018, classificados como reclamação trabalhista. Desse montante, duas inicias foram desconsideradas da amostra, uma era uma reapresentação de um processo no qual o reclamante não havia comparecido na audiência e, a outra, a própria fundação interpôs uma ação em razão de um auto de infração do Ministério Público do Trabalho (MTE). Ao final, 78 iniciais estavam arquivadas de maneira digital na base de dados do setor jurídico da instituição, ou seja, quase a totalidade das reclamações. As outras 12 iniciais remanescentes foram analisadas através da cópia física dos processos e posteriormente digitalizadas.

Através do Gráfico 8 é possível visualizar a distribuição das 90 reclamações endereçadas a instituição ao longo do período.

Gráfico 8 - Total de Reclamações Trabalhistas ajuizadas de 2010 até 2018 na OS

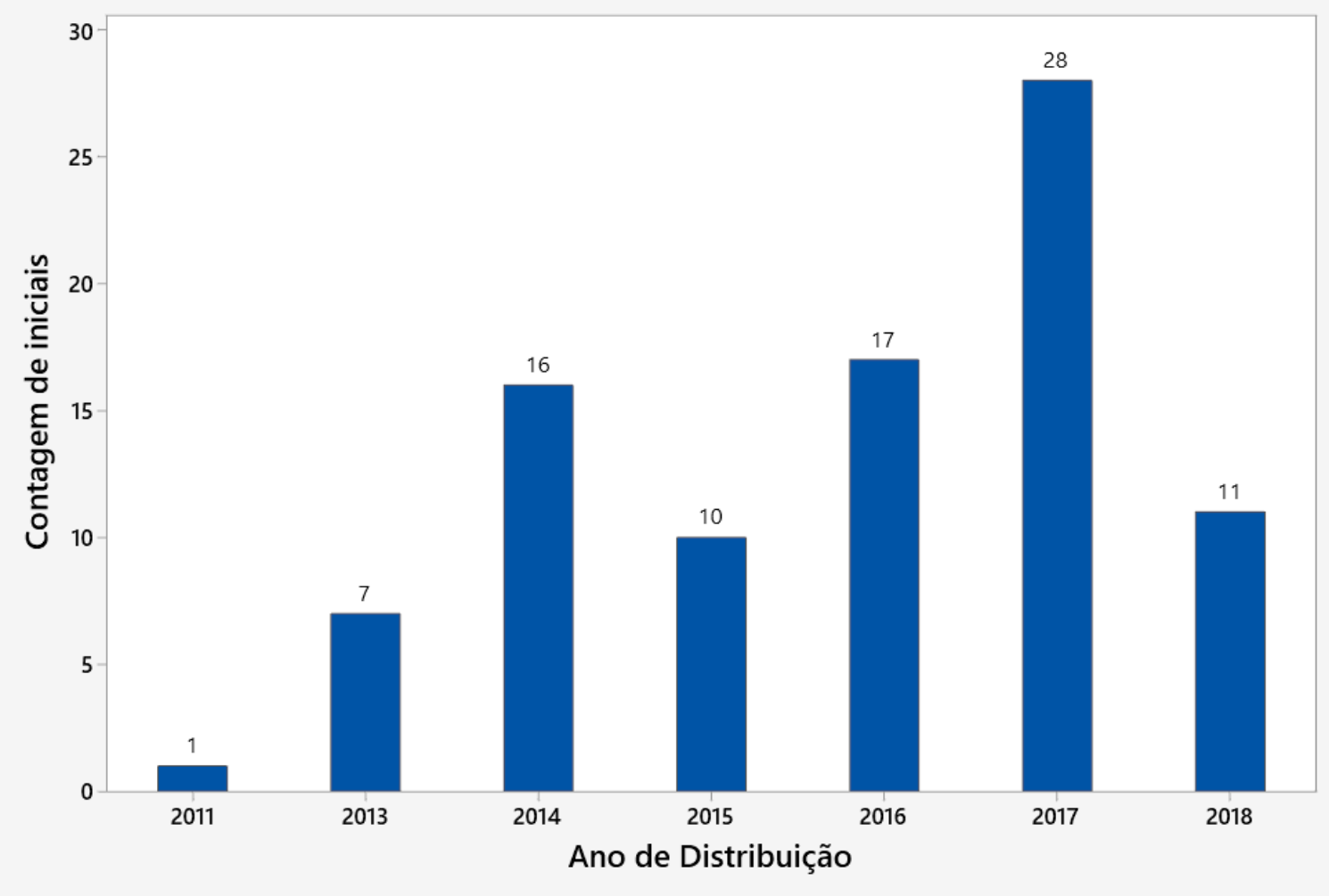

Fonte: elaborado pelo autor. 
Outra informação demonstrada através do Gráfico 9, é de que a maioria dos ritos empregados nos processos é o ordinário, ou seja, é quando o valor da causa ultrapassa 40 (quarenta) salários mínimos. Esse tipo de rito normalmente é utilizado em situações com maior valor de causa. Em contrapartida o rito sumaríssimo aparece em bem menor escala, é quando a causa tem valor de 2 (dois) até 40 (quarenta) salários mínimos.

Gráfico 9 - Distribuição de Reclamações Trabalhistas conforme o rito de 2010 até 2018 na OS

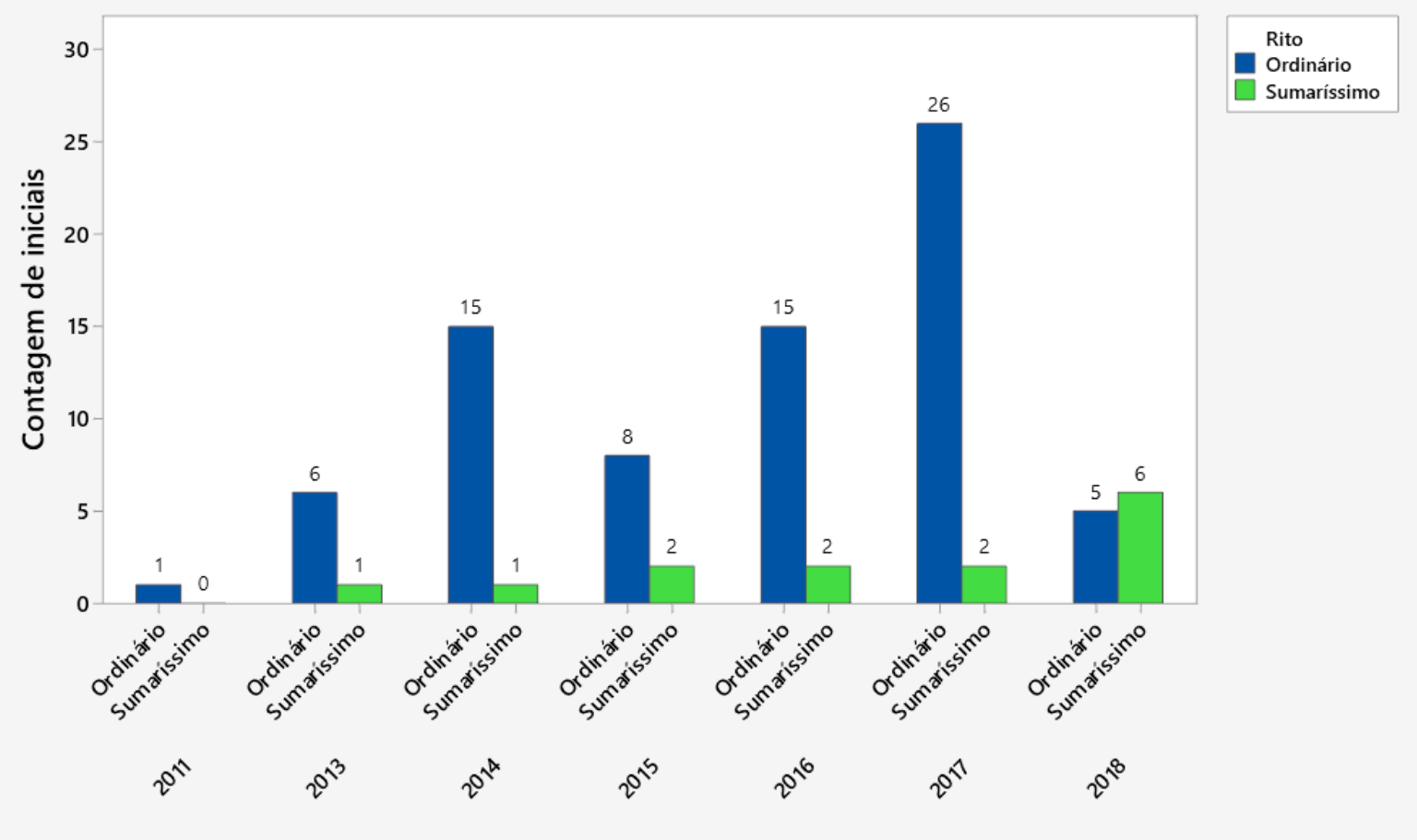

Fonte: elaborado pelo autor.

Referente aos assuntos mais recorrentes nos processos, após a análise dos discursos e a definição das expressões chaves e ideias centrais contidas em cada inicial, a Tabela 1 retrata os dados quantificados e categorizados. Os assuntos foram agrupados para facilitar a discussão futura, de forma que, ao longo de cada evidência localizada no discurso houve sua associação a uma respectiva categoria - cada evidência foi contabilizada apenas uma única vez por discurso. Por fim, as categorias formadas por ideias centrais que destoavam dos processos de GP foram descartadas da análise, como: "tutela de urgência", "intimação da parte adversa", "juntada de documentos", "prioridade na tramitação, tutela de urgência ou antecipada" "encaminhamento para apuração a outros órgãos públicos", "juros e correção monetária", "honorários advocatícios sucumbenciais", "justiça gratuita", "expedir notificações em nome do advogado". 
Tabela 1 - Distribuição total por categorias dos discursos na OS

\begin{tabular}{|c|c|}
\hline Categoria: palavra-chave & Quantidade \\
\hline Pagamento de diferenças nas verbas contratuais ou rescisórias & 75 \\
\hline Pagamento de horas extras & 51 \\
\hline Nulidade ou controvérsia na demissão & 50 \\
\hline Responsabilidade subsidiária e/ou solidária & 45 \\
\hline Pagamento de multas & 41 \\
\hline Controvérsia na natureza jurídica da Fundação & 39 \\
\hline Indenização por danos materiais & 39 \\
\hline Reintegração com ou sem readaptação & 38 \\
\hline Indenização pela supressão de intervalos & 33 \\
\hline Desvio, acúmulo de função e equiparação salarial & 32 \\
\hline Pagamento de folgas e feriados trabalhados & 31 \\
\hline Nulidade do banco de horas & 28 \\
\hline Pagamento do adicional de insalubridade & 28 \\
\hline Pagamento do adicional noturno & 23 \\
\hline Indenização por danos morais pela demora no agendamento da homologação ou dispensa & 22 \\
\hline Conversão ou controvérsia da jornada de trabalho & 15 \\
\hline Indenização por danos morais pelo não fornecimento de EPI & 14 \\
\hline Indenização por danos morais pelas condições de trabalho & 14 \\
\hline Indenização por danos morais por assédio moral & 14 \\
\hline Indenização por lucros cessantes, reparação ou valores descontados & 12 \\
\hline Indenização por danos morais devido a dores e doenças ocupacionais & 9 \\
\hline Pagamento da dobra das férias & 9 \\
\hline Pagamento do adicional de periculosidade & 6 \\
\hline Pedido de perícia técnica & 7 \\
\hline Preenchimento ou correção da CTPS & 7 \\
\hline Responsabilidade objetiva & 7 \\
\hline Pagamento de pensão vitalícia & 5 \\
\hline Pagamento de adicional de sobreaviso & 3 \\
\hline Estabilidade provisória & 2 \\
\hline Nulidade da redução salarial & 2 \\
\hline Indenização por dano existencial & 1 \\
\hline Pedido de rescisão indireta & 1 \\
\hline Pagamento de benefícios & 1 \\
\hline Total & 704 \\
\hline
\end{tabular}

Fonte: elaborado pelo autor.

Outro dado relevante encontrado e não esperado durante o levantamento dos resultados, é de que a grande maioria das iniciais analisadas partiram de um mesmo advogado ou escritório. Conforme descrito no Gráfico 10, do total de iniciais analisadas, cerca de 48 partiram de um mesmo sujeito ou escritório de advocacia, ou seja, $53,3 \%$ das inicias. Em contrapartida, o restante das 42 iniciais da amostra analisada, permanecem divididas entre outros 28 advogados. 
Gráfico 10 - Distribuição de inicias por advogado ou escritório da parte contrária na OS
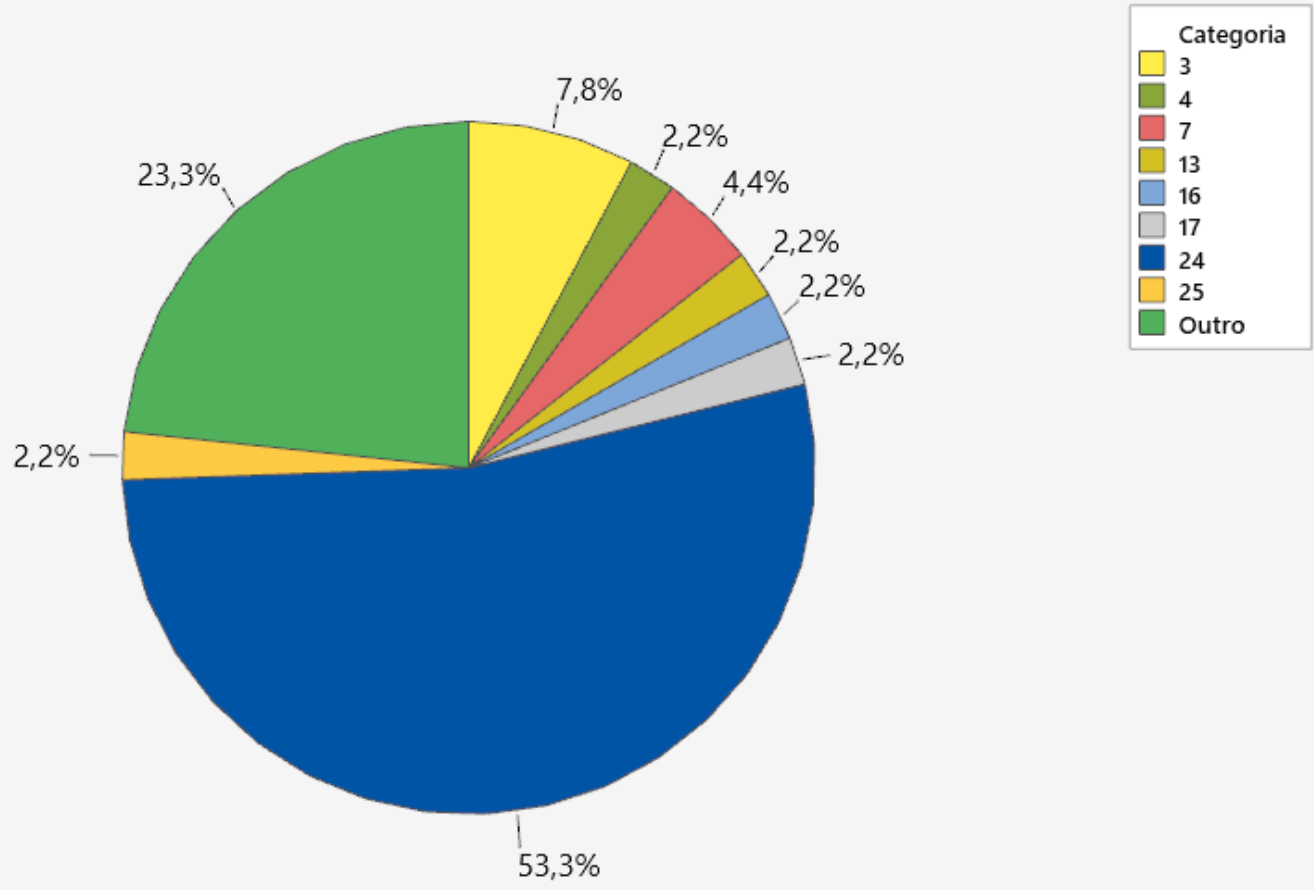

Categorias com percentual menor que ou igual a 2\% estão combinadas em "Outro" Fonte: elaborado pelo autor.

\subsection{RESULTADOS QUALITATIVOS}

\subsubsection{Categorias}

Para obtenção dos resultados qualitativos partiu-se para o estudo de cada petição inicial. Através da metodologia do DSC foram identificadas as expressões chaves e as ideias centrais. Posteriormente, as ideias centrais foram associadas em categorias, as quais receberam um nome, gerando enfim a categorização dos dados. Em razão da pequena representatividade constatada na análise quantitativa de alguns assuntos, a construção do DSC foi realizada somente para os assuntos que apareceram pelo mais de três vezes.

\subsubsection{Macrocategorias}

A fim de atender os objetivos do estudo e identificar qual processo de GP desfere maior impacto no ajuizamento das reclamações trabalhistas foram criadas seis macrocategorias para sistematizar as representações sociais identificadas. As 
macrocategorias seguiram o conceito dos processos de agregar, aplicar, recompensar, desenvolver, manter e monitorar pessoas de Chiavenato (2014). De forma que, as categorias do DSC identificadas, foram associadas a uma respectiva macrocategorias, através da análise do conteúdo de cada categoria, identificado o processo da GP com maior relação com a solicitação - o que possibilitou agrupar e confrontar cada uma delas com as atividades de GP.

\section{a) Agregar pessoas}

A primeira macrocategoria foi associada as categorias que demonstraram prevalência com algum tipo de conflito nos processos de suprimento de pessoal, 0 qual está estritamente relacionado ao fato de encontrar e estabelecer a relação de trabalho com os recursos humanos. Isso envolve desde o processo de recrutamento e seleção e depende de diversos fatores, como: o crescimento econômico, a natureza e qualidade dos postos de trabalho, a produtividade e a inserção no mercado.

Dessa forma, a categoria "controvérsia na natureza jurídica da Fundação" foi incluída nessa macrocategoria, por seu discurso referir-se diretamente a definição das características contratuais da organização, ou seja, a presente controvérsia no formato que a mesma estabelece as relações de trabalho com os recursos humanos.

Em valores quantitativos, a macrocategoria obteve 39 evidências associadas, em uma única categoria.

\section{b) Aplicar pessoas}

Nesta macrocategoria foram associadas as categorias estritamente ligadas ao processo de integração, o desenho do cargo e a avaliação de desempenho, ou seja, os conflitos relacionados a recepcionar e posicionar os recursos humanos corretamente dentro da organização. Aqui foram alocadas as categorias: "conversão ou controvérsia da jornada de trabalho"; "desvio, acúmulo de função e equiparação salarial"; "preenchimento ou correção da CTPS". As quais remetem as possíveis falhas na definição da jornada definida para cargo e o não respeito a legislação vigente e os desvios frente ao desenho do cargo, sem a devida compensação. 
Em valores quantitativos, a macrocategoria obteve 54 evidências associadas, ao longo de 3 categorias.

c) Recompensar pessoas

As categorias aqui relacionadas tratam dos discursos indicativos de conflitos nos sistemas de recompensas (remuneração fixa, variável, benefícios, etc.) da organização. Dessa forma, as categorias aqui incluídas, foram: "indenização por danos morais pela demora no agendamento da homologação ou dispensa"; "indenização por lucros cessantes, reparação ou valores descontados"; "nulidade da redução salarial"; "nulidade do banco de horas"; "pagamento da dobra das férias"; "pagamento de adicional de sobreaviso"; "pagamento de benefícios"; "pagamento de diferenças nas verbas contratuais ou rescisórias"; "pagamento de folgas e feriados trabalhados"; "pagamento de horas extras"; "pagamento de multas"; "pagamento do adicional de insalubridade"; "pagamento do adicional de periculosidade"; "pagamento do adicional noturno".

Em valores quantitativos, a macrocategoria obteve o maior número de 332 evidências ao longo de 14 associadas.

\section{d) Desenvolver pessoas}

Esta macrocategoria não teve nenhuma categoria associada, pois tratava dos processos diretamente relacionados aos fundamentos de treinamentos, programas de mudanças organizacionais e desenvolvimento de carreira. Dessa forma, não foram identificados quaisquer pedidos relacionados as falhas em tais processos.

e) Manter pessoas

Foram associados a essa macrocategoria as categorias: "estabilidade legal e constitucional"; "indenização pela supressão de intervalos"; "indenização por dano existencial”; "indenização por danos materiais"; "indenização por danos morais devido a dores e doenças ocupacionais"; "indenização por danos morais pelas condições de trabalho"; "indenização por danos morais pelo não fornecimento de EPI"; "nulidade ou 
controvérsia na demissão"; "pagamento de pensão vitalícia"; "pedido de perícia técnica"; "pedido de rescisão indireta"; "reintegração com ou sem readaptação"; "responsabilidade objetiva"; "responsabilidade subsidiária e/ou solidária".

Tais categorias estão direcionadas aos processos que promovem as condições ambientais e psicológicas de trabalho para as pessoas em suas atividades cotidianas, como: as relações com empregados e sindicatos, higiene, segurança e qualidade de vida. Em valores quantitativos, a macrocategoria obteve o segundo maior número de 265 evidências, ao longo de 14 categorias associadas.

f) Monitorar pessoas

Por fim, essa macrocategoria recebeu os itens relacionados aos processos de monitorar pessoas, em suma, isso significa seguir, acompanhar, orientar e manter o comportamento das pessoas, conforme as expectativas institucionais. A única categoria associada aqui foi a referente a "indenização por danos morais por assédio moral".

Em valores quantitativos, a macrocategoria obteve 14 evidências associadas, em uma única categoria.

\subsubsection{Distribuição das categorias}

Por fim, com o objetivo de demonstrar a distribuição das temáticas contidas na amostra do estudo, a Tabela 2 retrata como cada categoria foi associada, conforme sua macrocategoria correspondente.

Tabela 2 - Distribuição das categorias em macrocategorias

\begin{tabular}{lcc}
\hline Macrocategorias & $\mathbf{N}$ & $\%$ \\
\hline Agregar Pessoas & $\mathbf{3 9}$ & $\mathbf{5 , 5 4 \%}$ \\
\hline Controvérsia na natureza jurídica da Fundação & 39 & $5,54 \%$ \\
\hline Aplicar Pessoas & $\mathbf{5 4}$ & $\mathbf{7 , 6 7 \%}$ \\
\hline Conversão ou controvérsia da jornada de trabalho & 15 & $2,13 \%$ \\
\hline Desvio, acúmulo de função e equiparação salarial & 32 & $4,55 \%$ \\
\hline Preenchimento ou correção da CTPS & 7 & $0,99 \%$ \\
\hline Manter Pessoas & $\mathbf{2 6 5}$ & $\mathbf{3 7 , 6 4} \%$ \\
\hline Estabilidade provisória & 2 & $0,28 \%$ \\
\hline Indenização pela supressão de intervalos & 33 & $4,69 \%$ \\
\hline Indenização por dano existencial & 1 & $0,14 \%$ \\
\hline Indenização por danos materiais & 39 & $5,54 \%$ \\
\hline
\end{tabular}




\begin{tabular}{|c|c|c|}
\hline Indenização por danos morais devido a dores e doenças ocupacionais & 9 & $1,28 \%$ \\
\hline Indenização por danos morais pelas condições de trabalho & 14 & $1,99 \%$ \\
\hline Indenização por danos morais pelo não fornecimento de EPI & 14 & $1,99 \%$ \\
\hline Nulidade ou controvérsia na demissão & 50 & $7,10 \%$ \\
\hline Pagamento de pensão vitalícia & 5 & $0,71 \%$ \\
\hline Pedido de perícia técnica & 7 & $0,99 \%$ \\
\hline Pedido de rescisão indireta & 1 & $0,14 \%$ \\
\hline Reintegração com ou sem readaptação & 38 & $5,40 \%$ \\
\hline Responsabilidade objetiva & 7 & $0,99 \%$ \\
\hline Responsabilidade subsidiária e/ou solidária & 45 & $6,39 \%$ \\
\hline Monitorar Pessoas & 14 & $1,99 \%$ \\
\hline Indenização por danos morais por assédio moral & 14 & $1,99 \%$ \\
\hline Recompensar Pessoas & 332 & $47,16 \%$ \\
\hline Indenização por danos morais pela demora no agendamento da homologação ou dispensa & 22 & $3,13 \%$ \\
\hline Indenização por lucros cessantes, reparação ou valores descontados & 12 & $1,70 \%$ \\
\hline Nulidade da redução salarial & 2 & $0,28 \%$ \\
\hline Nulidade do banco de horas & 28 & $3,98 \%$ \\
\hline Pagamento da dobra das férias & 9 & $1,28 \%$ \\
\hline Pagamento de adicional de sobreaviso & 3 & $0,43 \%$ \\
\hline Pagamento de benefícios & 1 & $0,14 \%$ \\
\hline Pagamento de diferenças nas verbas contratuais ou rescisórias & 75 & $10,65 \%$ \\
\hline Pagamento de folgas e feriados trabalhados & 31 & $4,40 \%$ \\
\hline Pagamento de horas extras & 51 & $7,24 \%$ \\
\hline Pagamento de multas & 41 & $5,82 \%$ \\
\hline Pagamento do adicional de insalubridade & 28 & $3,98 \%$ \\
\hline Pagamento do adicional de periculosidade & 6 & $0,85 \%$ \\
\hline Pagamento do adicional noturno & 23 & $3,27 \%$ \\
\hline Total Geral & 704 & $100,00 \%$ \\
\hline
\end{tabular}

Fonte: elaborado pelo autor.

\subsubsection{Distribuição das macrocategorias}

Por fim, após cada categoria ser ligada a um respectivo processo de GP responsável pelo seu surgimento, tornou-se possível visualizar através da Tabela 3 as macrocategorias com maior impacto no ajuizamento das reclamações trabalhistas e consequentemente os processos de GP com maior relevância dentre as petições iniciais. 
Tabela 3 - Distribuição percentual das macrocategorias (2010-2018)

\begin{tabular}{|c|c|c|c|c|c|c|c|c|c|c|c|c|}
\hline & 2010 & 2011 & 2012 & 2013 & & 2014 & & 2015 & 2016 & 2017 & 2018 & Total \\
\hline Agregar Pessoas & $0,0 \%$ & $0,0 \%$ & $0,0 \%$ & $0,1 \%$ & & $0,9 \%$ & & $0,6 \%$ & $1,1 \%$ & $2,7 \%$ & $0,1 \%$ & $5,5 \%$ \\
\hline Controvérsia na natureza jurídica da Fundação & $0,0 \%$ & $0,0 \%$ & $0,0 \%$ & $0,1 \%$ & & $0,9 \%$ & & $0,6 \%$ & $1,1 \%$ & $2,7 \%$ & $0,1 \%$ & $5,5 \%$ \\
\hline Aplicar Pessoas & $0,0 \%$ & $0,0 \%$ & $0,0 \%$ & $0,4 \%$ & & $1,0 \%$ & & $0,6 \%$ & $1,6 \%$ & $3,8 \%$ & $0,3 \%$ & $7,7 \%$ \\
\hline Conversão ou controvérsia da jornada de trabalho & $0,0 \%$ & $0,0 \%$ & $0,0 \%$ & $0,0 \%$ & & $0,0 \%$ & & $0,1 \%$ & $0,3 \%$ & | $1,7 \%$ & $0,0 \%$ & $2,1 \%$ \\
\hline Desvio, acúmulo de função e equiparação salarial & $0,0 \%$ & $0,0 \%$ & $0,0 \%$ & $0,1 \%$ & & $0,9 \%$ & & $0,1 \%$ & $1,1 \%$ & $2,1 \%$ & $0,1 \%$ & $4,5 \%$ \\
\hline Preenchimento ou correção da CTPS & $0,0 \%$ & $0,0 \%$ & $0,0 \%$ & $0,3 \%$ & & $0,1 \%$ & & $0,3 \%$ & $0,1 \%$ & $0,0 \%$ & $0,1 \%$ & $1,0 \%$ \\
\hline Manter Pessoas & $0,0 \%$ & $0,0 \%$ & $0,0 \%$ & $2,0 \%$ & ] & $5,1 \%$ & 1 & $3,5 \%$ & $8,9 \%$ & $16,2 \%$ & $1,8 \%$ & $37,6 \%$ \\
\hline Estabilidade provisória & $0,0 \%$ & $0,0 \%$ & $0,0 \%$ & $0,3 \%$ & & $0,0 \%$ & & $0,0 \%$ & $0,0 \%$ & $0,0 \%$ & $0,0 \%$ & $0,3 \%$ \\
\hline Indenização pela supressão de intervalos & $0,0 \%$ & $0,0 \%$ & $0,0 \%$ & $0,1 \%$ & & $0,6 \%$ & & $0,1 \%$ & $1,1 \%$ & $2,4 \%$ & $0,3 \%$ & $4,7 \%$ \\
\hline Indenização por dano existencial & $0,0 \%$ & $0,0 \%$ & $0,0 \%$ & $0,0 \%$ & & $0,0 \%$ & & $0,0 \%$ & $0,0 \%$ & $0,1 \%$ & $0,0 \%$ & $0,1 \%$ \\
\hline Indenização por danos materiais & $0,0 \%$ & $0,0 \%$ & $0,0 \%$ & $0,3 \%$ & | & $0,4 \%$ & & $0,4 \%$ & $1,6 \%$ & $2,8 \%$ & $0,0 \%$ & $5,5 \%$ \\
\hline Indenização por danos morais devido a dores e doenças ocupacionais & $0,0 \%$ & $0,0 \%$ & $0,0 \%$ & $0,0 \%$ & & $0,3 \%$ & & $0,3 \%$ & $0,7 \%$ & $0,0 \%$ & $0,0 \%$ & $1,3 \%$ \\
\hline Indenização por danos morais pelas condições de trabalho & $0,0 \%$ & $0,0 \%$ & $0,0 \%$ & $0,1 \%$ & & $0,3 \%$ & & $0,1 \%$ & $0,1 \%$ & $1,1 \%$ & $0,1 \%$ & $2,0 \%$ \\
\hline Indenização por danos morais pelo não fornecimento de EPI & $0,0 \%$ & $0,0 \%$ & $0,0 \%$ & $0,0 \%$ & & $0,0 \%$ & & $0,0 \%$ & $0,6 \%$ & | $1,4 \%$ & $0,0 \%$ & $2,0 \%$ \\
\hline Nulidade ou controvérsia na demissão & $0,0 \%$ & $0,0 \%$ & $0,0 \%$ & $0,4 \%$ & I & $1,3 \%$ & & $0,7 \%$ & $1,4 \%$ & $2,8 \%$ & $0,4 \%$ & $7,1 \%$ \\
\hline Pagamento de pensão vitalícia & $0,0 \%$ & $0,0 \%$ & $0,0 \%$ & $0,0 \%$ & & $0,3 \%$ & & $0,0 \%$ & $0,3 \%$ & $0,1 \%$ & $0,0 \%$ & | $0,7 \%$ \\
\hline Pedido de perícia técnica & $0,0 \%$ & $0,0 \%$ & $0,0 \%$ & $0,0 \%$ & & $0,3 \%$ & & $0,0 \%$ & $0,1 \%$ & $0,0 \%$ & $0,6 \%$ & $1,0 \%$ \\
\hline Pedido de rescisão indireta & $0,0 \%$ & $0,0 \%$ & $0,0 \%$ & $0,1 \%$ & & $0,0 \%$ & & $0,0 \%$ & $0,0 \%$ & $0,0 \%$ & $0,0 \%$ & $0,1 \%$ \\
\hline Reintegração com ou sem readaptação & $0,0 \%$ & $0,0 \%$ & $0,0 \%$ & $0,4 \%$ & $\mid$ & $0,6 \%$ & & $0,9 \%$ & $1,0 \%$ & | $2,3 \%$ & $0,3 \%$ & $5,4 \%$ \\
\hline Responsabilidade objetiva & $0,0 \%$ & $0,0 \%$ & $0,0 \%$ & $0,0 \%$ & & $0,3 \%$ & & $0,3 \%$ & $0,3 \%$ & $0,1 \%$ & $0,0 \%$ & $1,0 \%$ \\
\hline Responsabilidade subsidiária e/ou solidária & $0,0 \%$ & $0,0 \%$ & $0,0 \%$ & $0,1 \%$ & & $0,9 \%$ & & $0,7 \%$ & $1,7 \%$ & $2,8 \%$ & $0,1 \%$ & $6,4 \%$ \\
\hline Monitorar Pessoas & $0,0 \%$ & $0,0 \%$ & $0,0 \%$ & $0,0 \%$ & & $0,1 \%$ & & $0,0 \%$ & $1,0 \%$ & $0,7 \%$ & $0,1 \%$ & | $2,0 \%$ \\
\hline Indenização por danos morais por assédio moral & $0,0 \%$ & $0,0 \%$ & $0,0 \%$ & $0,0 \%$ & & $0,1 \%$ & & $0,0 \%$ & $1,0 \%$ & $0,7 \%$ & $0,1 \%$ & $2,0 \%$ \\
\hline Recompensar Pessoas & $0,0 \%$ & $0,0 \%$ & $0,0 \%$ & | $2,4 \%$ & 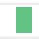 & $6,4 \%$ & 1 & $3,7 \%$ & $10,4 \%$ & $18,9 \%$ & $5,5 \%$ & $47,2 \%$ \\
\hline Indenização por danos morais pela demora no agendamento da homologação ou dispensa & $0,0 \%$ & $0,0 \%$ & $0,0 \%$ & $0,0 \%$ & & $0,0 \%$ & & $0,0 \%$ & $0,7 \%$ & $2,1 \%$ & $0,3 \%$ & $3,1 \%$ \\
\hline Indenização por lucros cessantes, reparação ou valores descontados & $0,0 \%$ & $0,0 \%$ & $0,0 \%$ & $0,0 \%$ & & $0,4 \%$ & & $0,3 \%$ & $0,4 \%$ & $0,3 \%$ & $0,3 \%$ & $1,7 \%$ \\
\hline Nulidade da redução salarial & $0,0 \%$ & $0,0 \%$ & $0,0 \%$ & $0,0 \%$ & & $0,1 \%$ & & $0,0 \%$ & $0,0 \%$ & $0,1 \%$ & $0,0 \%$ & $0,3 \%$ \\
\hline Nulidade do banco de horas & $0,0 \%$ & $0,0 \%$ & $0,0 \%$ & $0,1 \%$ & & $0,0 \%$ & & $0,0 \%$ & $1,0 \%$ & $2,4 \%$ & $0,4 \%$ & $4,0 \%$ \\
\hline Pagamento da dobra das férias & $0,0 \%$ & $0,0 \%$ & $0,0 \%$ & $0,0 \%$ & & $0,0 \%$ & & $0,0 \%$ & $0,0 \%$ & $0,9 \%$ & $0,4 \%$ & $1,3 \%$ \\
\hline Pagamento de adicional de sobreaviso & $0,0 \%$ & $0,0 \%$ & $0,0 \%$ & $0,1 \%$ & & $0,3 \%$ & & $0,0 \%$ & $0,0 \%$ & $0,0 \%$ & $0,0 \%$ & $0,4 \%$ \\
\hline Pagamento de benefícios & $0,0 \%$ & $0,0 \%$ & $0,0 \%$ & $0,0 \%$ & & $0,0 \%$ & & $0,0 \%$ & $0,1 \%$ & $0,0 \%$ & $0,0 \%$ & $0,1 \%$ \\
\hline Pagamento de diferenças nas verbas contratuais ou rescisórias & $0,0 \%$ & $0,0 \%$ & $0,0 \%$ & $0,7 \%$ & I & $2,1 \%$ & & $1,0 \%$ & $2,0 \%$ & $3,4 \%$ & | $1,4 \%$ & $10,6 \%$ \\
\hline Pagamento de folgas e feriados trabalhados & $0,0 \%$ & $0,0 \%$ & $0,0 \%$ & $0,0 \%$ & & $0,0 \%$ & & $0,1 \%$ & $0,9 \%$ & $2,8 \%$ & $0,6 \%$ & $4,4 \%$ \\
\hline Pagamento de horas extras & $0,0 \%$ & $0,0 \%$ & $0,0 \%$ & $0,4 \%$ & & $1,4 \%$ & & $0,4 \%$ & $1,4 \%$ & $2,6 \%$ & $1,0 \%$ & $7,2 \%$ \\
\hline Pagamento de multas & $0,0 \%$ & $0,0 \%$ & $0,0 \%$ & $0,4 \%$ & & $0,9 \%$ & & $0,7 \%$ & $1,7 \%$ & $2,0 \%$ & $0,1 \%$ & $5,8 \%$ \\
\hline Pagamento do adicional de insalubridade & $0,0 \%$ & $0,0 \%$ & $0,0 \%$ & $0,3 \%$ & & $0,7 \%$ & & $0,4 \%$ & $1,1 \%$ & $0,6 \%$ & $0,9 \%$ & $4,0 \%$ \\
\hline Pagamento do adicional de periculosidade & $0,0 \%$ & $0,0 \%$ & $0,0 \%$ & $0,0 \%$ & & $0,1 \%$ & & $0,3 \%$ & $0,3 \%$ & $0,1 \%$ & $0,1 \%$ & $1,0 \%$ \\
\hline Pagamento do adicional noturno & $0,0 \%$ & $0,0 \%$ & $0,0 \%$ & $0,3 \%$ & & $0,3 \%$ & & $0,4 \%$ & $0,7 \%$ & $1,6 \%$ & $0,0 \%$ & $3,3 \%$ \\
\hline Total & $0,0 \%$ & $0,0 \%$ & $0,0 \%$ & $5,0 \%$ & & $13,5 \%$ & & $8,4 \%$ & $23,0 \%$ & $42,3 \%$ & $7,9 \%$ & $100,0 \%$ \\
\hline
\end{tabular}

Fonte: elaborado pelo autor. 


\subsubsection{Dendograma}

Com o objetivo de demonstrar os principais agrupamentos nos dados, conforme as categorias levantadas, o Gráfico 11 traz o diagrama em forma dendograma, o qual é capaz de representar quais categorias estão mais correlacionados nas iniciais trabalhistas da OS.

Gráfico 11 - Dendograma

\section{Dendrograma}

Ligação Completa; Distância do Coeficiente de Correlação

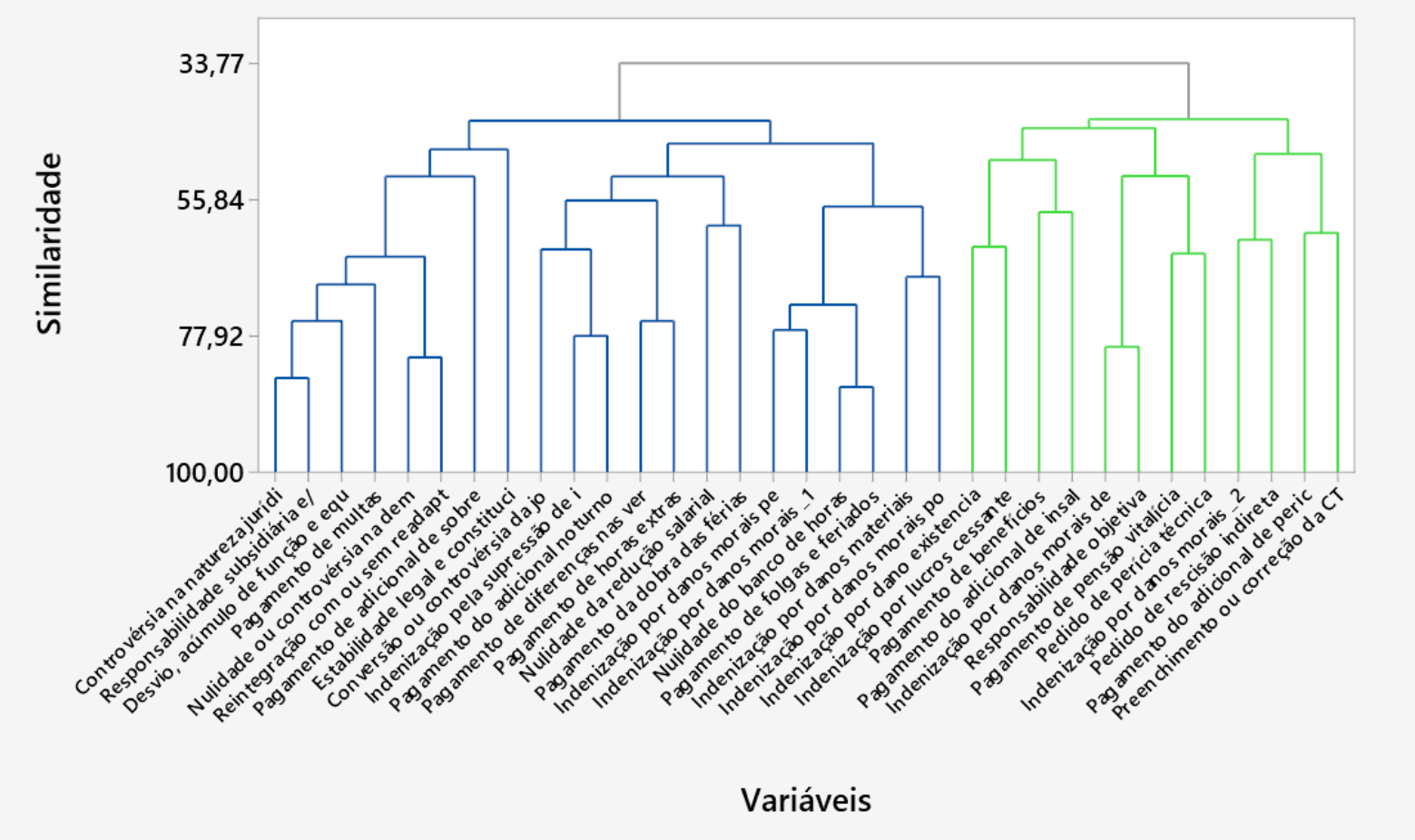

Fonte: elaborado pelo autor.

Dessa maneira, é possível observar uma similaridade significativa (próximo de 100) entre as algumas categorias, como: "controvérsia na natureza jurídica da Fundação" e "responsabilidade subsidiária e/ou solidária", "nulidade ou controvérsia na demissão" e "reintegração com ou sem readaptação", "nulidade do banco de horas" e "pagamento de folgas e feriados trabalhados" e também entre a "indenização por danos morais devido a dores e doenças ocupacionais" e a "responsabilidade objetiva".

Outra informação relevante e visível através do Gráfico 11 é a divisão dos agrupamentos, em que o agrupamento maior (em azul) representa em sua maioria $o$ conteúdo presente nas reclamações que partiram de um mesmo escritório ou advogado. 
Além disso, é possível visualizar outros agrupamentos nos dados, contudo, em razão da diminuição de sua similaridade, os mesmos não serão levados em consideração na discussão. 
5 DISCUSSÃO 


\section{DISCUSSÃo}

A partir dos resultados apresentados, o estudo evidenciou as principais características das alegações contidas nos pedidos nas iniciais das ações trabalhistas de uma OS e, apesar de utilizar uma metodologia específica frente a categorização dos dados, uma parte dos achados apresentaram semelhança aos previamente supracitadas ao longo do levantamento teórico. Na comparação, é válido destacar o aumento exponencial no ajuizamento das reclamações trabalhistas até o ano de 2017 e, no ano subsequente, a queda no número de casos novos. Portanto, talvez a amostra do estudo possa ter sofrido impacto direto do advento da Lei 13.467 de 2017, a reforma trabalhista. Após sua aprovação, o ano de 2018 apresentou considerável redução no número de casos novos - possivelmente alavancada pelas mudanças na Lei. Além disso, no mesmo ano, houve uma equiparação entre o tipo de rito das reclamações trabalhistas. Tal fato deixou a quantidade de processos com rito sumaríssimo próxima aos de rito ordinário. Outro ponto de convergência está na temática dos pedidos das iniciais analisadas, os quais, em sua maioria, estão relacionados ao pagamento de diferenças nas verbas contratuais ou rescisórias e 0 pagamento de multas.

Uma das possíveis justificativas para a diminuição no quantitativo de casos e alteração do tipo de rito das reclamações pode estar relacionada ao novo dispositivo da reforma trabalhista, o art. 791-A, que disciplina sobre os honorários advocatícios na Justiça do Trabalho, revogando entendimento anteriores das Súmulas n 219 e 329 do TST. Nele são alterados aspectos ligados a gratuidade em estabelecer os honorários advocatícios e a sucumbência recíproca. Essa, possivelmente é uma das alterações mais significativas da reforma, pois influência diretamente no protecionismo processual, o qual "...é um dos pilares de sustentação do processo trabalhista e, pode em muitos casos inviabilizar ou ser um fator inibitório do acesso à justiça da parte economicamente fraca." (SHIAVI, 2017, p. 85). Apesar dos indícios, o presente estudo não é munido de evidências para promover uma discussão aprofundada sobre tal aspecto e, neste ponto, tem por objetivo aguçar projetos futuros que possam explorar tal tema.

Embora existam similaridades, foi possível identificar uma particularidade na amostra analisada. A maioria das petições partiram de um único escritório ou advogado e, consequentemente, grande parte do discurso contido nas iniciais repetiu- 
se em praticamente em todas as reclamações, com apenas algumas particularidades de cada caso. Essas condições demonstram a existência de um agrupamento (cluster) nos dados e a discussão sobre o fato tornou-se determinante para a compreensão dos resultados. Portanto, é interpretável que os dados sofreram impacto direto desse agrupamento e, por conta disso, os resultados obtidos pelo estudo permaneceram limitados. Inclusive, para a evidenciar tal fato não houve necessidade de uma análise do agrupamento mais aprofundada, pois sua interpretação foi de fácil visualização por estar na origem dos dados, de forma que, em todas as categorias que apresentaram alta similaridade estavam presentes na maioria dos processos ajuizados dessa fonte, ou seja, a grande maioria dos processos ajuizados por tal escritório continham pedidos parecidos, além de um discurso repetido na maioria das reclamações.

Apesar disso, foi possível demonstrar através da caracterização dos dados e conforme os métodos para análise empregados, a distribuição dos processos de GP na amostra e, consequentemente, os principais padrões das matérias reclamadas. Ficou evidenciado que os processos de recompensar e manter pessoas conferem o maior volume categorias associadas, ou seja, são os processos que mais influenciam no ajuizamento das reclamações trabalhistas. Ademais, tais processos são os que sofreram maior aumento ao longo da série histórica estudada, chegando ao auge no ano de 2017.

Ao aprofundarmos a discussão, ao longo da construção dos DSC e consequentemente das categorias, foi possível observar que o discurso contido nas iniciais estavam impregnadas pela interferência dos moldes coercitivos e repreensivos das regras jurídicas. Certamente é de interesse do Direito proteger somente atos morais, porém, nem sempre é possível, pode ocorrer que atos permitidos pela lei não sejam morais, ocasionando contrastes interpretativos sobre os conceitos. As regras morais são cumpridas de maneira espontânea, sem qualquer tipo de imposição; diferente das regras jurídicas, que contam com a presença da coerção e repressão, podem ser injustas ou não, sob pena de punição enquanto a mesma não for revogada (FONSECA, 2009).

Ao aprofudar a discussão, é possivel citar Almeida (2012) que na tentativa de demonstrar a interdisciplinaridade entre os processos da GP e o Direito do Trabalho, diante da situação econômica, social e cultural do Brasil, realizou a análise da aplicabilidade da assessoria jurídica em cada um dos seis principais processos de GP 
(agregar, aplicar, recompensar, desenvolver, manter e monitorar pessoas). Ficou demonstrado a difícil tarefa de gerir e aplicar tais processos, sem esbarrar em algum problema legal, ou ainda, acarretar em algum ônus à organização. De certa forma, as organizações passaram por diversas mudanças na forma de administrar os recursos humanos e tal desacordo entre a Lei e a prática das organizações dificulta a implantação e a manutenção dos processos da GP. Em partes, isso permanece apoiado no nascimento da legislação brasileira, a qual teve como premissa combater a exploração e a desigualdade - o que pode justificar seu caráter protecionista e que inclusive mantém essa base sem muitas alterações até a atualidade. Além disso, e conforme apontado no estudo, a assessoria jurídica preventiva é uma das possíveis saídas para lidar com essa realidade.

Amaral (2014) também avaliou através de um estudo o impacto da assessoria jurídica preventiva e sua atuação conjunta com a GP, retratando os efeitos sobre o número de ações judiciais trabalhistas de uma organização de cunho comercial. Como resultado, encontrou fragilidades no preparo do gestor de recursos humanos, o qual, normalmente gerencia o desenvolvimento e desempenho de tais processos e também dos gestores, os quais contam com uma preocupação genérica sobre os processos trabalhistas. O estudo concluiu que no período em que assessoria jurídica trabalhista atuou de maneira preventiva, foi possível observar um resultado positivo na organização, com a diminuição no quantitativo de processos trabalhistas e na possibilidade de redução de seu passivo trabalhista, o que evidência a importância de ter-se como aliada a assessoria jurídica na atuação da GP.

Por conta disso, é possível justificar o alto volume de pedidos característicos aos processos de recompensar pessoas. Tais processos estão estritamente emparelhados com as atividades mais antigas da GP e relacionados ao DP. Essa área foi uma das primeiras relacionada aos recursos humanos a surgir no âmbito organizacional. De acordo com Chiavenato (2014) os processos de recompensar condizem com remuneração total que uma pessoa recebe pelo seu trabalho, é composta pela remuneração básica ou salário e a remuneração variável, a qual é utilizada para incrementar os resultados, a criatividade, a inovação, o espírito empreendedor e a iniciativa.

Portanto, neste ponto é possível evidenciar que tal macrocategoria sofre com uma carga considerável de interferência do Estado em sua composição e que as leis 
trabalhistas do Brasil podem refletir diretamente em desdobramentos para tais direitos. Além disso, é valido ressaltar a importância de as organizações avançarem no cumprimento das leis em vigência e atuar diretamente no desenvolvimento das relações de emprego.

Adiante, é possível destacar o relacionamento dos processos de recompensar e manter pessoas com os processos de monitorar na organização, esses estão ligados ao acompanhamento do comportamento das pessoas de maneira democrática e participativa. Ou seja, o controle não é mais externo, impositivo e coercitivo, e sim, baseado no conhecimento e com informações recebidas através do desempenho das atividades e demais contribuições. (CHIAVENATO, 2014). Em ambas as macrocategorias de manter e recompensar foi possível observar a divergência entre o desenvolvimento organizacional e social ante ao avanço das leis trabalhistas e da organização. Ao longo dos DSC construídos para nas macrocategorias fica sugestivo que o monitoramento do comportamento dos integrantes da organização deva ser feito de maneira impositiva e coercitiva ao contrário do sugerido pelos achados teóricos. Outra vertente que justifica o ajuizamento de tais pedidos é de que a organização possa estar falhando na maneira como tem conduzido as estratégias de monitoramento do pessoal, acarretando em falhas desde a obtenção até a tomada de decisão ante ao processamento das informações e administração de pessoal, gerando assim conflitos relacionados aos processos de manter e recompensar - isso fica evidente pelo número de pedidos relacionados a pagamentos ou diferenças que não foram previamente gerenciadas por tal processo.

Por fim, a macrocategoria de agregar pessoas, a segunda com maior relevância, apresenta aspectos ligados com as condições de trabalho, os quais são determinantes para assegurar a saúde física e mental das pessoas. Em teoria, envolve temáticas sobre o ambiente físico que envolve boa iluminação, ventilação, temperatura, ruído; um ambiente psicológico sadio de trabalho, com relacionamentos e atividades agradáveis, estilo participativo e a eliminação de fontes de estresse; com ergonomia, máquinas e equipamentos adequados e ferramentas que reduzam o esforço físico; a saúde ocupacional com a correta gestão dos riscos físicos, biológicos, tóxicos e químicos e condições estressantes, através de um programa, com indicadores, regras e procedimentos preventivos e de recompensa (CHIAVENATO, 2014). Na macrocategoria aparecem alguns dos itens com maior relevância na 
amostra do estudo, sua formação advém primordialmente de algumas características do local do estudo e que estão relacionados às configurações de uma OS. Como os discursos das categorias de "nulidade ou controvérsia na demissão", "reintegração com ou sem readaptação" e "responsabilidade subsidiária e/ou solidária", que aparecem impregnados de argumentos rebatendo a configuração das OS, resultando principalmente no pedido de enquadramento desse tipo de organização como de caráter público.

$\mathrm{Na}$ macrocategoria referente aos processos de agregar pessoas, o discurso referente a natureza da OS elenca a representação social predominante sobre seu caráter privado. Contudo, seu funcionamento recai sobre o uso de recursos financeiros e da prestação serviço na área pública. Em suma, apesar da OS ter sido constituída no campo privado, de acordo com o discurso, a mesma deve obedecer às obrigações e normas de uma entidade pública - já que presta um serviço que é de responsabilidade do Estado para a sociedade. Isso tudo, aproxima a OS do contexto público e consequentemente de seu modelo de administração.

Todavia, na apreciação da bibliográfica levantada, fica evidente que o objetivo da efetivação das OS é de se afastar do modelo da administração pública, principalmente em virtude de sua ineficiência e capacidade de adaptação às novas exigências da sociedade. Em resumo, é possível destacar que: "de certa forma, o Poder Público assenhoreia-se do controle da entidade privada: com a colaboração da comunidade - para que ela possa vir a exercer as atividades sociais desejadas, utilizando-se de recursos oficiais". (MEIRELLES, 2016, p. 284). Ou seja, é evidente que ao mesmo tempo em que existe uma proximidade, o papel real do Poder Público é de administrar as OS e, de certa forma, isso tem causado confusão diante de suas reais obrigações, vale citar:

Hoje, essa advertência deve ser mitigada em determinadas relações do Direito Privado com o Direito Público, pois não se pode desconsiderar que o Direito Administrativo vem passando por substanciais transformações e mudanças de paradigma, fazendo com que, em determinadas questões, seu estudo e sua aplicação não possam ficar presos à dicotomia entre Direito Público e Direito Privado. Com efeito, em determinadas áreas, gestões inovadoras estão miscigenando regras próprias de Direito Privado com as de Direito Público, especialmente na legislação relativa à "privatização" de serviços públicos, buscando atender às cada vez maiores exigências sociais, especialmente na sua prestação, como, por exemplo, ocorre com a Lei 9.63 $7 / 98$, das chamadas organizações sociais, examinada no item 7.1.2 do Cap. VI. 14. Essa miscigenação exige redobrada cautela no trabalho de interpretação e nas decisões, mas nunca deixando de considerar permanente 
atenção sobre a incidência dos princípios constitucionais que regem o Direito Administrativo. (MEIRELLES, 2016, p. 46).

Também é possível demonstrar o impacto da flexibilização na administração da OS, já que praticamente todas as petições iniciais exigiram que a natureza da Instituição fosse tida como de caráter público e, por fim, garantido os direitos condizentes com a referida constatação.

Durante a análise dos agrupamentos encontrados, destaca-se pedidos relacionados a particularidade da constituição jurídica da Fundação. Com uma similaridade alta nos processos entre as categorias de "controvérsia na natureza jurídica da Fundação", "nulidade ou controvérsia na demissão" e a "reintegração". Que aparentam estar relacionados as características presentes na OS, pois não foram encontradas tais temáticas no referencial teórico, ou seja, aparentemente são uma particularidade.

Ainda é valido ressaltar que nenhum requerimento envolveu diretamente os processos de desenvolvimento de pessoal, o que pode incitar no distanciamento dessa questão aos olhos da legislação, da própria parte reclamante, ou ainda enseja que realmente a organização venha atendendo as demandas de maneira satisfatória frente a esses processos.

Por fim, apesar dos fatores que impactaram e revelaram possível um viés frente ao estudo, ainda é adequado utilizá-lo como meio de demonstrar o quanto as leis trabalhistas possivelmente estão subsidiando pedidos que poderem não fazer mais parte da realidade das organizações, sendo que, logo após a aprovação da reforma, diminuíram drasticamente o volume de casos novos. 
6 CONCLUSÃO 


\section{CONCLUSÃO}

O desenvolvimento do presente estudo possibilitou a compreensão sobre as reclamações trabalhistas de uma OS e demonstrar como os processos de GP podem ser utilizados como base teórica na predição, prevenção e correção das causas contidas nas reclamações trabalhistas. Dessa forma, o estudo não teve a pretensão de apresentar resultados que comprovassem uma estratégia efetiva para a redução das reclamações trabalhistas, ao invés disso se propôs em identificar causas e características acerca das reclamações trabalhistas e melhorar a compreensão sobre o tema, bem como avaliar sua relação com as estratégias de GP. Outro ponto, foi discutir sobre as principais características da sociedade e da Justiça do Trabalho no Brasil - aspectos que são de extrema relevância e influenciam nas relações de emprego. Ao final do estudo é factível apreciar achados consistentes e outros ainda preliminares.

Os dados foram trabalhados de forma quantitativa e qualitativa. Sendo que na etapa de análise dos DSC foi possível categorizar e demonstrar o funcionamento das estratégias de GP e seus possíveis reflexos no campo organizacional. O que tornou evidente a discrepância ou conflito entre o ajuizamento de matérias e as estratégias de GP e o impacto dos processos de recompensar e manter na gestão das organizações. Neste ponto, é evidente que esses processos da GP devem ser tomados como prioridade no contexto da organização, pois já que apresentam maior número de ocorrências, desenvolvê-los consequentemente traria maior chance de reduzir o ajuizamento de reclamações trabalhistas. Outro fato observado é de que em alguns aspectos, as leis não acompanharam o desenvolvimento das organizações e da sociedade, isso pode estar reduzindo condutas consideras morais dentro do contexto organizacional, como sendo contrarias a lei.

Por fim, é possível concluir que reclamações trabalhistas estavam aumentando gradativamente ao longo do tempo, até acontecer a reforma trabalhista, que aparentemente mudou o cenário e, inclusive, alterou o padrão nas matérias reclamadas. Que a somatória das transformações na sociedade e o exercício da Justiça do Trabalho no Brasil são fatores que influenciam diretamente no ajuizamento das reclamações trabalhistas. Em contrapartida, o papel de GP tem ganhado destaque neste embate por tornar viável alterações no escopo organizacional capazes de influenciar diretamente no ajuizamento de ações. 
Assim, a amostra sofreu com o impacto da reforma trabalhista e do agrupamento de ações advindos de um mesmo escritório. Isso demonstra os limites e a importância de desenvolver novos estudos, não somente com a inicias de cada reclamação e sim avaliar cada caso após o julgamento de todo processo, os quais não estavam dentro das possibilidades desse estudo. Dito isso, é indispensável que o tema deva ser abordado em outros trabalhos. Também imprescindível uma amostragem maior e capaz de representar de forma mais totalitária as demais organizações. 


\section{REFERÊNCIAS}

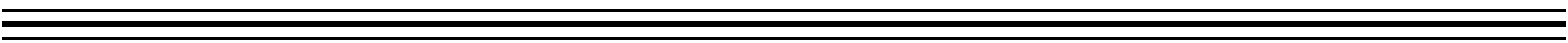




\section{REFERÊNCIAS}

ALMEIDA, A. S. Direito do trabalho e gestão de pessoas: a interdisciplinaridade e a importância da assessoria jurídica preventiva. In: Âmbito Jurídico, Rio Grande, XV, n. 100, maio 2012. Disponível em:

<http://ambitojuridico.com.br/site/?n_link=revista_artigos_leitura\&artigo_id=11515> Acesso em: 01 out. 2017.

AMARAL, J. M. N. A assessoria jurídica preventiva na gestão dos processos trabalhistas. 2014. 120 f. Dissertação (Mestrado em Gestão de Organizações Aprendentes) - Universidade Federal da Paraíba, João Pessoa, 2014.

<http://tede.biblioteca.ufpb.br:8080/handle/tede/5941 > Acesso em: 01 out. 2017.

BAUMAN, Z. Tempos líquidos. Rio de Janeiro: Jorge Zahar, 2007.

BRASIL. Constituição (1988). Constituição da República Federativa do Brasil. Brasília, Distrito Federal: Senado, 1988. Disponível em:

<http://www.planalto.gov.br/ccivil_03/constituicao/constituição.htm>. Acesso em: 01 out. 2017.

Decreto-lei no 5452 , de 1 de maio de 1943. Aprova a consolidação das leis do trabalho. Diário Oficial da União, Brasília, Distrito Federal, 09 ago. 1943.

Disponível em: < http://www.planalto.gov.br/ccivil_03/decreto-lei/Del5452.htm>. Acesso em: 01 out. 2017.

. Lei oㅜ 13.105, de 16 de março de 2015. Código de Processo Civil. Diário Oficial da União, Brasília, Distrito Federal, 17 mar. 2015. Disponível em: <http://www.planalto.gov.br/ccivil_03/_ato2015-2018/2015/lei/13105.htm>. Acesso em: 01 out. 2017.

. Lei n. 9.637, de 15 de maio de 1998: Dispõe sobre a qualificação de entidades como organizações sociais, a criação do Programa Nacional de Publicização, a extinção do laboratório Nacional de Luiz Sincrotron e da Fundação Roquette Pinto e a absorção de suas atividades por organizações sociais, e dá outras providências. Diário Oficial da União, Brasília, 25 mai. 1998a. Disponível em: <http://www.planalto.gov.br/ccivil_03/Leis//9637.htm>. Acesso em: 11 de jun. 2018.

Lei no 13.467, de 13 de julho de 2017. Altera a Consolidação da Leis do Trabalho (CLT). Diário Oficial da União, Brasília, Distrito Federal, 13 jul. 2017. Disponível em: <http://www.planalto.gov.br/ccivil_03/_ato20152018/2017/lei/13467.htm>. Acesso em: 13 ago. $201 \overline{.}$.

BRIDGES, W., Mudança nas relações de trabalho: como ser bem sucedido em um mundo sem empregos, São Paulo, Makron, 1995.

CHIAVENATO, I. Gestão de pessoas: o novo papel dos recursos humanos nas organizações, 4ª . Ed. São Paulo: Manole, 2014. 
CHOHFI, T; CHOHFI, M. C. Relações sindicais e negociações trabalhistas. 1a. Ed. Rio de Janeiro: Forense, 2011.

DUTRA, J. S.; DUTRA, T. A.; DUTRA, G. A. Gestão

de Pessoas: realidade atual e desafios futuros. 1a. Ed. São Paulo: Atlas, 2017.

DESSLER, G. Administração de Recursos Humanos. 3a. Ed. São Paulo: Pearson Education do Brasil, 2014.

DELGADO, M. G. Direitos Fundamentais nas Relações de Trabalho. Revista de Direito e Garantias Fundamentais, Espírito Santo, n. 2, 2007. Disponível em: $<$ http://sisbib.emnuvens.com.br/direitosegarantias/article/download/40/38>. Acesso em: 11 de jun. 2018.

FERNANDES, B. H. R. Gestão estratégica de pessoas com foco em competência. Rio de Janeiro: Elsevier, 2013

FREITAS, G de; FUGULIN, F. M. T.; FERNANDES, M. de F. P. A regulação das relações de trabalho e o gerenciamento de recursos humanos em enfermagem.

Revista da Escola de Enfermagem da USP, São Paulo, v. 40, n. 3, p. 434-438, set. 2006. Disponível em: <http://dx.doi.org/10.1590/S0080-62342006000300017>.

Acesso em: 08 set. 2017.

FILGUEIRAS, V. A.; LIMA, U. M.; SOUZA, I. F. de. OS IMPACTOS JURÍDICOS, ECONÔMICOS E SOCIAIS DAS REFORMAS TRABALHISTAS. Cad. CRH, Salvador, v. 32, n. 86, p. 231-252, ago. 2019. Disponível em $<$ http://www.scielo.br/scielo.php?script=sci_arttext\&pid=S010349792019000200231\&lng=pt\&nrm=iso >. acessos em 27 out. 2019. Epub 10-Out2019. http://dx.doi.org/10.9771/ccrh.v32i86.30731.

FRIEDMAN, T. L. O mundo é plano: uma breve história do século XXI. 3ª . Ed. São Paulo: Companhia das Letras, 2014

FONSECA, M. H. Departamento pessoal: relações trabalhistas e sindicais. Rio de Janeiro: Editora Ciência Moderna Ltda., 2009.

Direito ao trabalho: um direito fundamental no ordenamento jurídico brasileiro. 2006. 383 f. Tese (Doutorado em Direito) - Pontifícia Universidade Católica de São Paulo, São Paulo, 2006. Disponível em:

$<$ https://tede2.pucsp.br/handle/handle/7259> Acesso em: 11 de jun. 2018

GALVAO, Andréia et al. REFORMA TRABALHISTA: precarização do trabalho e os desafios para o sindicalismo. Cad. CRH, Salvador, v. 32, n. 86, p. 253-270, ago. 2019. Disponível em

<http://www.scielo.br/scielo.php?script=sci_arttext\&pid=S0103-

49792019000200253\&lng=pt\&nrm=iso>. acessos em 27 out. 2019. Epub 10-Out2019. http://dx.doi.org/10.9771/ccrh.v32i86.30691.

GIL, A. C. Como elaborar projetos de pesquisa. 6ª . Ed. São Paulo:

Atlas, 2002. 
Atlas, 2008.

Métodos e técnicas de pesquisa social. 4⿳亠丷a . Ed. São Paulo:

HAIR Jr, J. F. Análise multivariada de dados. Tradução Adonai Schlup

Sant'Anna. 6. ed. Porto Alegre: Bookman, 2009.

HEAB. HOSPITAL ESTADUAL AMERICO BRASILIENSE. A História do Hospital Estadual Américo Brasiliense. Disponível em:

http://www.heab.fmrp.usp.br/Home/Conteudo?ldNoticia=4>. Acesso em: 29/09/2017.

IBANEZ, N.; VECINA NETO, G. Modelos de gestão e o SUS. Ciênc. saúde

coletiva, Rio de Janeiro, v. 12, supl. p. 1831-1840, nov. 2007. Disponível em:

$<$ http://www.scielo.br/scielo.php?script=sci_arttext\&pid=S1413-

81232007000700006\&lng=en\&nrm=iso >. Acesso em: 11 de jun. 2018.

IBGE. INSTITUTO BRASILEIRO DE GEOGRAFIA E ESTATÍSTICA. Pesquisa nacional por amostra de domicílios (PNAD). Rio de Janeiro: IBGE, 2017 Disponível em:

<http://www.ibge.gov.br/home/estatistica/populacao/trabalhoerendimento/>. Acesso em: 14 set. 2017.

KREIN, J. D. O desmonte dos direitos, as novas configurações do trabalho e o esvaziamento da ação coletiva: consequências da reforma trabalhista. Tempo soc., São Paulo, v. 30, n. 1, p. 77-104, Apr. 2018. Available from $<$ http://www.scielo.br/scielo.php?script=sci_arttext\&pid=S010320702018000100077\&lng=en\&nrm=iso>. Acesso em: 27 set. 2019. 2019. http://dx.doi.org/10.11606/0103-2070.ts.2018.138082.

LEFEVRE, F.; LEFEVRE, A. M. C. Discurso do sujeito coletivo: representações sociais e intervenções comunicativas. Texto contexto - enferm., Florianópolis, v. 23, n. 2, p. 502-507, June 2014. Available from $<$ http://www.scielo.br/scielo.php?script=sci arttext\&pid=S0104$07072014000200502 \&$ Ing=en\&nrm=iso>. Acesso em: 14 abr. 2018. . http://dx.doi.org/10.1590/0104-07072014000000014.

LEFEVRE, F. Discurso do sujeito coletivo: nossos modos de pensar, nosso eu coletivo. 1a. Ed. São Paulo: Andreoli, 2017.

LOCH, C. L.; CORREIA, G. S. A flexibilização do trabalho e da gestão de pessoas limitadas pela racionalidade instrumental. Revista de Ciências da Administração, Florianópolis, p. 09-30, jan. 2004. ISSN 2175-8077. Disponível em: <https://periodicos.ufsc.br/index.php/adm/article/view/869>. Acesso em: 01 out. 2017.

MARQUES, L. F. et al.; SILVA, M, DE A, M. DA. A Gestão de Pessoas na Acreditação Hospitalar. In: Encontro de Gestão de Pessoas e Relações de Trabalho, 1, 2007, Natal/RN. Anais..., Natal/RN, ANPAD, 2007. Disponível em: http://www.anpad.org.br/admin/pdf/gpr2749.pdf 
MARTINS, M. I. C.; MOLINARO, A. Reestruturação produtiva e seu impacto nas relações de trabalho nos serviços públicos de saúde no Brasil. Ciência e saúde coletiva, Rio de Janeiro, v. 18, n. 6, p. 1667-1676, jun. 2013. Disponível em $<$ http://www.scielo.br/scielo.php?script=sci_arttext\&pid=S1413-

$81232013000600018 \&$ Ing=pt\&nrm=iso >. Acesso em: 08 set. 2017.

MAXIMINIANO, A. C. A. Teoria Geral da Administração. 2ª . Ed. São Paulo: Editora Atlas S.A., 2012.

MELO, C.; TANAKA, O. As organizações sociais no setor saúde: inovando as formas de gestão?. Organ. Soc., Salvador, v. 8, n. 22, p. 1-12, Dec. 2001. Available from $<$ http://www.scielo.br/scielo.php?script=sci_arttext\&pid=S198492302001000300007\&lng=en\&nrm=iso >. Acesso em: 26 out. 2019. http://dx.doi.org/10.1590/S1984-92302001000300007.

MEIRELES, H. L. Direito Administrativo Brasileiro, 21ª ed., São Paulo: Malheiros, 2008.

NASCIMENTO, A. M. Curso de direito do trabalho: história e teoria geral do direito do trabalho: relações individuais e coletivas do trabalho. 29 ed. São Paulo: Saraiva, 2014.

NOLETO, E. Q. (org.). Consolidação das leis do trabalho (CLT). Brasília: Câmara dos Deputados, Edições da Câmara, 2018.

OLIVEIRA, L. F. M. N. de. Gestão de pessoas em hospitais universitários: situação atual e tendências. 2013. Tese (Doutorado em Fundamentos e Administração de Práticas do Gerenciamento em Enfermagem) - Escola de Enfermagem, Universidade de São Paulo, São Paulo, 2013. Disponível em:< http://www.teses.usp.br/teses/disponiveis/7/7140/tde-12062013-131621/pt-br.php> Acesso em: 14 set. 2017.

OLIVEIRA, J. L. C. de; MATSUDA, L. M. Vantagens e dificuldades da acreditação hospitalar: A voz dos gestores da qualidade. Esc. Anna Nery, Rio de Janeiro, v. 20, n. 1, p. 63-69, Mar. 2016. Available from $<$ http://www.scielo.br/scielo.php?script=sci_arttext\&pid=S1414-

$81452016000100063 \& \operatorname{lng}=$ en\&nrm=iso $>$. Acesso em: 14 set. 2018. . http://dx.doi.org/10.5935/1414-8145.20160009.

PESSANHA, E. G. da F.; ARTUR, K. Direitos trabalhistas e organização dos trabalhadores num contexto de mudanças no mundo do trabalho: efeitos sobre os trabalhadores da saúde. Ciência e saúde coletiva, Rio de Janeiro, v. 18, n. 6, p. 1569-1580, jun. 2013. Disponível em:

<http://www.scielo.br/scielo.php?script=sci_arttext\&pid=S1413-

$81232013000600009 \&$ Ing=en\&nrm=iso>. Acesso em: 10 set. 2017.

PORTER, M. E.; TEISBERG, E. O. Repensando a saúde: estratégias para melhorar a qualidade e reduzir os custos. Tradução de Cristina Bazan. Porto Alegre:

Bookman, 2007. 
RAIS. RELAÇÃO ANUAL DE INFORMAÇÕES SOCIAIS. Ministério do Trabalho e Emprego. 2016.

RIFKIN, J. O fim dos empregos: O declínio inevitável dos níveis dos empregos e a redução da força global de trabalho. Tradução de Ruth Gabriela Bahr. São Paulo: Makron Books, 1995.

TST. TRIBUNAL SUPERIOR DO TRABALHO. Relatório geral da justiça do trabalho, 2016. Disponível em: <http://www.tst.jus.br/documents/10157/3bd84696-5b95-56dc1a66-29b804f92d39>. Acesso em: 29 set. 2017.

Relatório geral da justiça do trabalho, 2018. Disponível em:

<http://www.tst.jus.br/documents/18640430/24641384/RGJT+2018/a351ac73-a2fb3392-27f3-263c17e76517>. Acesso em: 07 ago. 2019.

UNESCO. ORGANIZAÇÃO DAS NAÇÕES UNIDAS PARA A EDUCAÇÃO, A CIÊNCIA E A CULTURA. Declaração Universal dos Direitos Humanos. Rio de Janeiro: UNIC, 2009 [1948]. Disponível em: <https://nacoesunidas.org/wpcontent/uploads/2018/10/DUDH.pdf>. Acesso em: 11 de jun. 2018.

UZZO, V. A reforma trabalhista necessária é possível. Estud. av., São Paulo, v. 18, n. 51, p. 209-218, Aug. 2004. Available from $<$ http://www.scielo.br/scielo.php?script=sci_arttext\&pid=S010340142004000200013\&lng=en\&nrm=iso >. Acesso em: 04 de ago. 2018.

VASCONCELLOS. M. A. S. de; GREMAUD, A. P.; TONETO JR., R. Economia Brasileira Contemporânea. 7a․ Ed. São Paulo: Editora Atlas S.A., 2013.

VERBICARO, L. P. Um estudo sobre as condições facilitadoras da judicialização da política no Brasil: a study about the conditions that make it possible. Rev. direito GV, São Paulo, v. 4, n. 2, p. 389-406, Dec. 2008. Disponível em:

$<$ http://www.scielo.br/scielo.php?script=sci_arttext\&pid=S1808-

$24322008000200003 \&$ Ing=en\&nrm=iso $>$. Acesso em: 11 de jun. 2018. 
APÊNDICE 


\title{
APÊNDICE A - CONSTRUÇÃO E ANÁLISE DOS DISCURSOS
}

\author{
a) agregar pessoas
}

- DCS: controvérsia na natureza jurídica da Fundação

\begin{tabular}{|c|c|c|}
\hline Palavra-Chave & Ideias Centrais & Discurso do Sujeito Coletivo \\
\hline $\begin{array}{l}\text { Controvérsia na } \\
\text { natureza jurídica } \\
\text { da Fundação }\end{array}$ & $\begin{array}{l}\text { a) A natureza jurídica da } \\
\text { fundação é privada, porém } \\
\text { administra recursos } \\
\text { públicos; } \\
\text { b) Origem dos recursos } \\
\text { destinados a } \\
\text { administração da } \\
\text { fundação são públicos; } \\
\text { c) Mediante convênio, a } \\
\text { fundação presta serviços } \\
\text { públicos na área da } \\
\text { saúde; }\end{array}$ & $\begin{array}{l}\text { Apesar de constar em seus atos constitutivos } \\
\text { e cadastros nos órgãos com a natureza jurídica } \\
\text { de fundação privada - a mesma é instituída } \\
\text { pelo poder público, com finalidade assistencial, } \\
\text { o qual participa de sua administração e a ela } \\
\text { destina recursos financeiros. Seu } \\
\text { funcionamento é mantido com dinheiro público } \\
\text { e também para serviços públicos, sem } \\
\text { qualquer concessão/privatização, mediante } \\
\text { simples convênio, devendo prestar contas ao } \\
\text { TCE, MP ontre outros } \\
\text { Consequentemente, é necessário declarar que } \\
\text { a fundação possui natureza jurídica de } \\
\text { Fundação Pública e deve estar submetida as } \\
\text { obrigações de entidade pública. }\end{array}$ \\
\hline
\end{tabular}

Sujeitos: $6,19,20,21,22,23,24,25,28,31,34,35,37,38,41,42,45,47,48,53,54,55,56,57$, $58,59,60,61,62,64,65,66,67,71,72,73,75,79,85$.

Processo da Gestão de Pessoas relacionado: Agregar pessoas

b) aplicar pessoas

- DCS: conversão ou controvérsia da jornada de trabalho

\begin{tabular}{|c|c|c|}
\hline Palavra-Chave & Ideias Centrais & Discurso do Sujeito Coletivo \\
\hline $\begin{array}{ll}\text { Conversão } & \text { ou } \\
\text { controvérsia } & \text { da } \\
\text { jornada } & \text { de } \\
\text { trabalho } & \end{array}$ & $\begin{array}{l}\text { a) Não concessão do } \\
\text { descanso interjornada; } \\
\text { b) Habitualidade da jornada } \\
\text { extraordinária; } \\
\text { c) Ilegalidade da escala } \\
12 \times 36 \text {. }\end{array}$ & $\begin{array}{l}\text { A reclamada não concedia o descanso } \\
\text { interjornada de } 36 \text { horas, habitualmente } \\
\text { prorrogava sua jornada de trabalho e não } \\
\text { recebia seu descanso intrajornada de uma } \\
\text { hora. A jornada de trabalho na modalidade } \\
12 \times 36 \text { é inconstitucional, visto que se os } \\
\text { artigos } 58 \text { da CLT e } 7^{\circ} \text {, XIII da CF estabelecem } \\
\text { a duração norma de trabalho não superior a } 08 \\
\text { horas diárias ou ainda o art. } 59 \text {, §ํㅡ, também }\end{array}$ \\
\hline
\end{tabular}




\begin{tabular}{|l|l|l|}
\hline & $\begin{array}{l}\text { da CLT limita a prorrogação para } 2 \text { horas } \\
\text { diárias, ou seja, o sistema 12x36 não atende } \\
\text { às exigências legais de regularidade do regime } \\
\text { de compensação horária, pois excede a 10 } \\
\text { horas por dia. Quando a reclamante trabalhava } \\
\text { em 4 plantões semanais, até ultrapassava a } \\
\text { jornada de } 44 \text { horas semanais, perfazendo } 48 \\
\text { horas. }\end{array}$ \\
\hline Sujeitos: $25,40,43,55,56,58,63,66,68,70,71,72,73,76,77$. \\
\hline Processo da Gestão de Pessoas relacionado: Aplicar pessoas
\end{tabular}

- DCS: desvio, acúmulo de função e equiparação salarial

\begin{tabular}{|l|l|l|}
\hline Palavra-Chave & Ideias Centrais & Discurso do Sujeito Coletivo \\
\hline $\begin{array}{l}\text { Desvio, acúmulo } \\
\text { de função e e Realizar outras funções } \\
\text { equiparação } \\
\text { salarial }\end{array}$ & $\begin{array}{l}\text { O pedido de acúmulo ou desvio de função } \\
\text { b) falta de compensação } \\
\text { salarial. }\end{array}$ & $\begin{array}{l}\text { ocorre pela prestação de serviços que não } \\
\text { correspondiam aos ora contratados. Isso, sem } \\
\text { a devida compensação salarial. Dessa forma } \\
\text { resta demonstrado que o acúmulo e o desvio } \\
\text { de função são tidos como ilícitos, pois são } \\
\text { caracterizados pela ordem unilateral do } \\
\text { empregador e ao mesmo tempo prejudicial ao } \\
\text { trabalhador que terá que assumir } \\
\text { responsabilidades e encargos superiores aos } \\
\text { limites pactuados. }\end{array}$ \\
\hline $\begin{array}{l}\text { Sujeitos: } 7,13,19,20,22,23,24,34,35,41,42,44,45,46,47,48,54,55,57,58,59,61,62,64, \\
65,66,67,68,71,73,79,82 .\end{array}$ \\
\hline Processo da Gestão de Pessoas relacionado: Aplicar pessoas \\
\hline
\end{tabular}

- DCS: preenchimento ou correção da CTPS

\begin{tabular}{|l|l|l|}
\hline Palavra-Chave & Ideias Centrais & Discurso do Sujeito Coletivo \\
\hline $\begin{array}{l}\text { Preenchimento ou } \\
\text { correção da CTPS }\end{array}$ & $\begin{array}{l}\text { a) Falta de preenchimento da } \\
\text { CTPS após a demissão; } \\
\text { b) Anotação da efetiva } \\
\text { função. }\end{array}$ & $\begin{array}{l}\text { Após a demissão não teve sua rescisão de } \\
\text { contrato de trabalho realizada, não teve a } \\
\text { baixa do contrato assinado em sua CTPS. O } \\
\text { empregado exercia outra função, a qual tinha } \\
\text { divergência da anotada em CTPS. }\end{array}$ \\
\hline
\end{tabular}

c) manter pessoas 
- DCS: estabilidade provisória

\begin{tabular}{|l|l|l|}
\hline Palavra-Chave & Ideias Centrais & Discurso do Sujeito Coletivo \\
\hline A construção do discurso foi descarta em razão da baixa representatividade. \\
\hline \\
\hline Sujeitos: $2,5$. \\
\hline Processo da Gestão de Pessoas relacionado: Manter pessoas
\end{tabular}

- DCS: indenização pela supressão de intervalos

\begin{tabular}{|c|c|c|}
\hline Palavra-Chave & Ideias Centrais & Discurso do Sujeito Coletivo \\
\hline $\begin{array}{lr}\text { Indenização } & \text { pela } \\
\text { supressão } & \text { de } \\
\text { intervalos } & \end{array}$ & $\begin{array}{l}\text { a) Intervalo antes do início do } \\
\text { período extraordinário; } \\
\text { b) Interrupção ou falta de } \\
\text { autorização para gozar do } \\
\text { intervalo; } \\
\text { c) Respeitar os intervalos } \\
\text { interjornada. }\end{array}$ & $\begin{array}{l}\text { O pedido de indenização pela supressão de } \\
\text { intervalo faz-se em razão do não cumprimento } \\
\text { de certas modalidades de intervalos, como: os } \\
15 \text { (quinze) minutos de intervalo antes do início } \\
\text { do período extraordinário. Além disso, embora } \\
\text { ocorresse o cumprimento da jornada de } \\
\text { trabalho por parte do trabalhador, o mesmo } \\
\text { não tinha autorização para gozar do intervalo } \\
\text { de } 1 \text { (uma) hora, quando concedia, acabava } \\
\text { interrompendo o intervalo para atender as } \\
\text { demandas do empregador. Outra modalidade } \\
\text { de intervalos é o de interjornada, com } 11 \\
\text { (onze) horas consecutivas para descanso } \\
\text { entre uma jornada e outra. }\end{array}$ \\
\hline
\end{tabular}

Sujeitos: $8,11,12,15,22,28,38,40,41,42,44,45,47,48,54,55,56,57,58,59,60,61,64,65$, 66, 71, 72, 73, 74, 76, 77, 82, 90.

Processo da Gestão de Pessoas relacionado: Manter pessoas

- DCS: indenização por dano existencial

\begin{tabular}{|l|l|l|}
\hline Palavra-Chave & Ideias Centrais & Discurso do Sujeito Coletivo \\
\hline
\end{tabular}


A construção do discurso foi descarta em razão da baixa representatividade.

Sujeitos: 74.

Processo da Gestão de Pessoas relacionado: Manter pessoas

- DCS: indenização por danos materiais

\begin{tabular}{|c|c|c|}
\hline Palavra-Chave & Ideias Centrais & Discurso do Sujeito Coletivo \\
\hline $\begin{array}{l}\text { Indenização por } \\
\text { danos materiais }\end{array}$ & $\begin{array}{l}\text { a) Indenizar pela propositura } \\
\text { da reclamação; } \\
\text { b) Desvio ou acúmulo de } \\
\text { função; } \\
\text { c) Métodos degradantes de } \\
\text { trabalho; } \\
\text { d) Acidente de trabalho; }\end{array}$ & $\begin{array}{l}\text { O pedido pela indenização por danos materiais } \\
\text { pela propositura da reclamação e em razão da } \\
\text { exposição do empregado a métodos } \\
\text { degradantes de trabalho, ou ainda, acidentes } \\
\text { que venham causar prejuízo a sua saúde física } \\
\text { elou psicológica, resultando na incapacidade } \\
\text { de exercer suas funções habituais e por esse } \\
\text { motivo teve diminuído o valor de seu trabalho, } \\
\text { situação essa que poderá inviabilizar ou, na } \\
\text { melhor das hipóteses, dificultar sobremaneira } \\
\text { a sua inserção no mercado de trabalho. Ainda } \\
\text { quando ocorre o exercício de função mais } \\
\text { qualificada sem compensação salarial ou } \\
\text { prejuízo financeiro ao mesmo de forma } \\
\text { inesperada. }\end{array}$ \\
\hline
\end{tabular}

Sujeitos: $4,8,12,13,17,25,26,27,35,37,38,41,42,44,45,46,47,48,49,52,54,55,56,57$, $58,59,60,61,62,64,65,67,68,71,72,73,76,77,79$.

Processo da Gestão de Pessoas relacionado: Manter pessoas

- DCS: indenização por danos morais devido a dores e doenças ocupacionais

\begin{tabular}{|l|l|l|}
\hline Palavra-Chave & Ideias Centrais & Discurso do Sujeito Coletivo \\
\hline Indenização por & a) submetida a formas e & Reclamante foi submetida a formas e métodos \\
danos morais & métodos degradantes à & degradantes à sua saúde física e psicológica \\
devido a dores e & sua saúde física e & que acabaram ocasionando-Ihe as patologias \\
doenças & psicológica; & que atualmente possui. Foi obrigada a exercer \\
ocupacionais & b) não fornecia & atividades que acabaram deteriorando sua \\
& equipamentos de & saúde física, vez que a Reclamada não Ihe \\
& segurança & proporcionava um ambiente de trabalho com \\
\hline
\end{tabular}




\begin{tabular}{|l|l|l|}
\hline & $\begin{array}{l}\text { segurança e vitalidade. Quanto à saúde e à } \\
\text { segurança, a Reclamada não fornecia } \\
\text { equipamentos de segurança que } \\
\text { proporcionasse proteção à saúde da } \\
\text { trabalhadora }\end{array}$ \\
\hline Sujeitos: $13,17,26,27,41,42,43,47,48$. \\
\hline Processo da Gestão de Pessoas relacionado: Manter pessoas \\
\hline
\end{tabular}

- DCS: indenização por danos morais pelas condições de trabalho

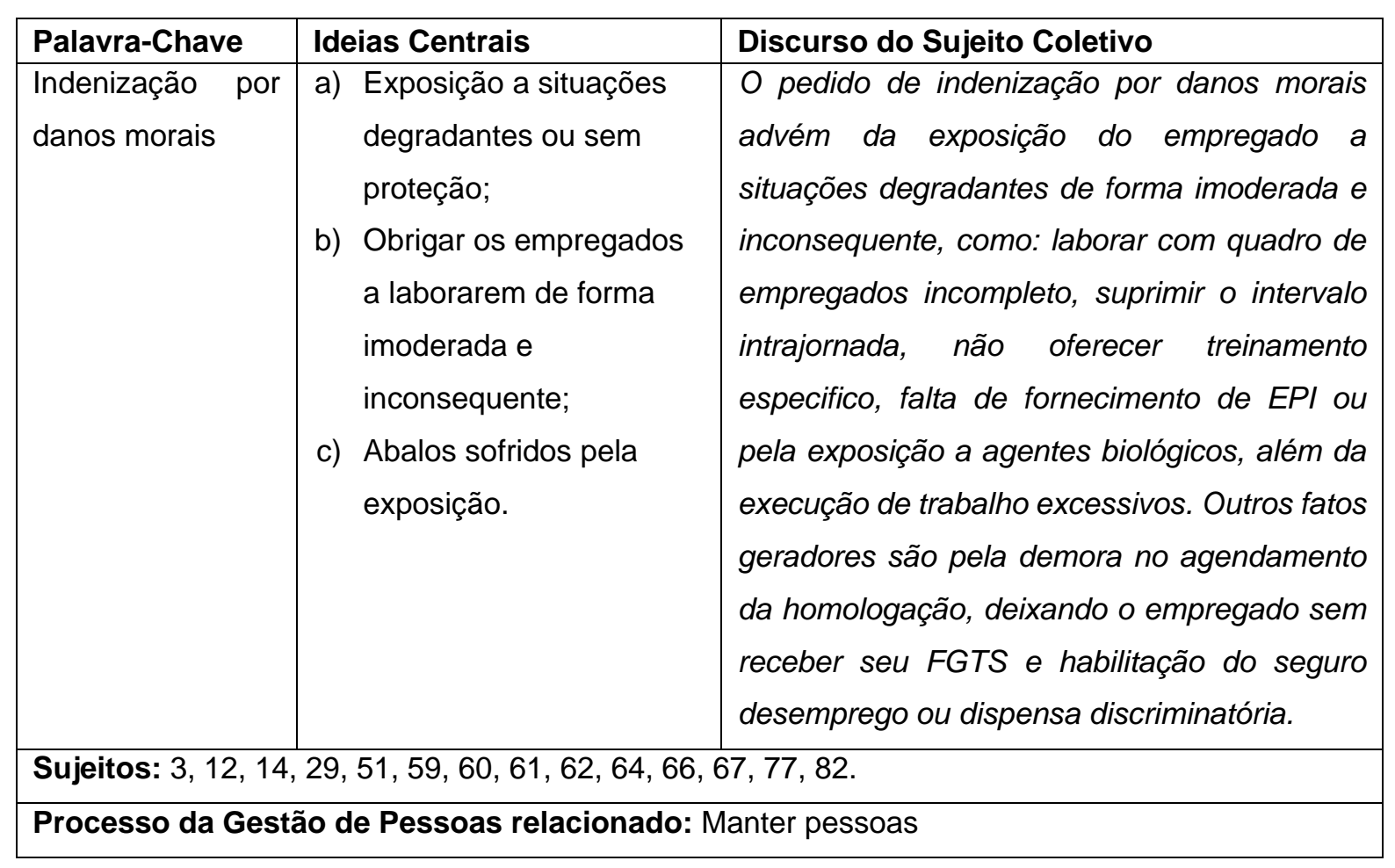

- DCS: indenização por danos morais pelo não fornecimento de EPI

\begin{tabular}{|c|c|c|}
\hline Palavra-Chave & Ideias Centrais & Discurso do Sujeito Coletivo \\
\hline $\begin{array}{l}\text { Indenização por } \\
\text { danos morais pelo } \\
\text { não fornecimento } \\
\text { de EPI }\end{array}$ & $\begin{array}{l}\text { a) Não fornecimento de EPI; } \\
\text { b) Exposição a agentes } \\
\text { biológicos; } \\
\text { c) Sempre ficou exposta, ela } \\
\text { sofreu grandes abalos } \\
\text { psicológicos }\end{array}$ & $\begin{array}{l}\text { Enquanto prestava seus serviços para a } \\
\text { Reclamada, estava exposta a agentes } \\
\text { biológicos, tais como: riscos de contaminação } \\
\text { hospitalar, e contato com pacientes com } \\
\text { doenças infectocontagiosas, como } \\
\text { tuberculosos, aidéticos, com hepatites, dentre } \\
\text { outros. A Reclamada não concedia o avental } \\
\text { plástico impermeável para neutralizar } \\
\text { quaisquer tipos de transmissão de agentes } \\
\text { biológicos. sempre ficou exposta, ela sofreu } \\
\text { grandes abalos psicológicos, pois sempre }\end{array}$ \\
\hline
\end{tabular}




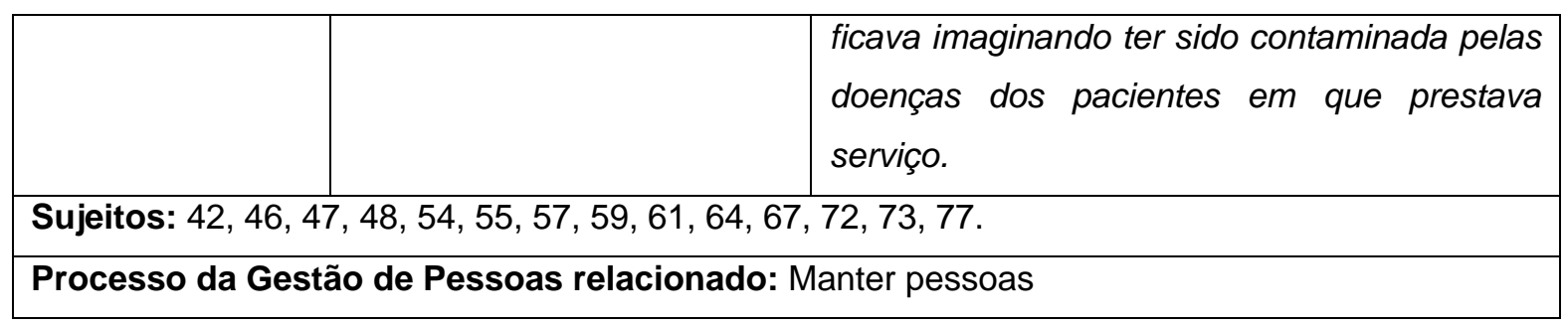

- DCS: nulidade ou controvérsia na demissão

\begin{tabular}{|c|c|c|}
\hline Palavra-Chave & Ideias Centrais & Discurso do Sujeito Coletivo \\
\hline $\begin{array}{ll}\text { Nulidade } & \text { ou } \\
\text { controvérsia } & \text { na } \\
\text { demissão } & \end{array}$ & $\begin{array}{l}\text { a) A demissão foi feita sem } \\
\text { respeitar as diretrizes do } \\
\text { serviço público; } \\
\text { b) Nulidade do pedido de } \\
\text { demissão; } \\
\text { c) Nulidade da Justa Causa. }\end{array}$ & $\begin{array}{l}\text { A nulidade do desligamento fica estabelecida } \\
\text { pois não houve processo administrativo para } \\
\text { assegurar a ampla defesa, ou ainda, quando } \\
\text { ocorre a justa causa sem o processo } \\
\text { administrativo. Também quando o indivíduo } \\
\text { não possui pleno gozo de suas faculdades } \\
\text { mentais e acaba por pedir seu a própria } \\
\text { demissão, a reclamada não poderia aceitar o } \\
\text { pedido de demissão. }\end{array}$ \\
\hline \multicolumn{3}{|c|}{$\begin{array}{l}\text { Sujeitos: } 2,5,6,9,14,18,19,20,21,22,23,24,25,28,31,32,34,35,39,41,42,44,45,46,47 \text {, } \\
48,51,53,54,55,56,57,58,59,60,61,62,64,65,66,67,71,72,73,75,77,79,80,85,90 .\end{array}$} \\
\hline
\end{tabular}

- DCS: pagamento de pensão vitalícia

\begin{tabular}{|c|c|c|}
\hline Palavra-Chave & Ideias Centrais & Discurso do Sujeito Coletivo \\
\hline $\begin{array}{l}\text { Pagamento de } \\
\text { pensão vitalícia }\end{array}$ & $\begin{array}{l}\text { a) Incapacidade parcial e } \\
\text { permanente; } \\
\text { b) Carregamento de pesos } \\
\text { excessivos no transporte } \\
\text { de pacientes; } \\
\text { c) Afastamento junto ao } \\
\text { INSS, }\end{array}$ & $\begin{array}{l}\text { Incapacitada parcial e permanente para } \\
\text { exercer suas atividades laborais e além disso } \\
\text { parcialmente incapacitada para exercer suas } \\
\text { atividades habituais, as quais se enquadram } \\
\text { como atividades cotidianas e diárias. Devido } \\
\text { às atividades desenvolvidas na empresa, o } \\
\text { que demonstra o nexo causal com o trabalho } \\
\text { exercido. Quando da ocorrência destes fatos, } \\
\text { a Reclamante entrou com o pedido de } \\
\text { afastamento junto ao INSS, e a Autarquia } \\
\text { Federal imediatamente concedeu o benefício. }\end{array}$ \\
\hline \multicolumn{3}{|c|}{ Sujeitos: $12,13,36,49,52$} \\
\hline \multicolumn{3}{|c|}{ Processo da Gestão de Pessoas relacionado: Manter pessoas } \\
\hline
\end{tabular}

- DCS: pedido de perícia técnica

\begin{tabular}{|l|l|l|}
\hline Palavra-Chave & Ideias Centrais & Discurso do Sujeito Coletivo \\
\hline
\end{tabular}




\begin{tabular}{|l|l|l|}
\hline Perícia técnica & $\begin{array}{l}\text { a) Adicional de insalubridade; } \\
\text { b) Falta ou irregularidade no } \\
\text { fornecimento de EPI }\end{array}$ & $\begin{array}{l}\text { Permanecia exposto diariamente aos riscos } \\
\text { inerentes à função exercida e independente do } \\
\text { uso de equipamentos de proteção individual e } \\
\text { do tempo de exposição, o risco de } \\
\text { contaminação em um hospital por agentes } \\
\text { biológicos é inerente às atividades, não } \\
\text { podendo ser eliminados com os EPIS. Os } \\
\text { EPIS, equipamentos que poderiam abrandar } \\
\text { as lesões causadas pelos agentes danosos à } \\
\text { saúde, não eram fornecidos com frequência } \\
\text { pela empresa e quando eram disponibilizados } \\
\text { estavam de maneira irregular. }\end{array}$ \\
\hline Sujeitos: $11,13,36,86,87,88,89$.
\end{tabular}

- DCS: pedido de rescisão indireta

\begin{tabular}{|l|l|l|}
\hline Palavra-Chave & Ideias Centrais & Discurso do Sujeito Coletivo \\
\hline A construção do discurso foi descarta em razão da baixa representatividade. \\
\\
\hline Sujeitos: 3 \\
\hline Processo da Gestão de Pessoas relacionado: Manter pessoas \\
\hline
\end{tabular}

- DCS: reintegração com ou sem readaptação

\begin{tabular}{|l|l|l|}
\hline Palavra-Chave & Ideias Centrais & Discurso do Sujeito Coletivo \\
\hline Reintegração & $\begin{array}{l}\text { a) Pessoa jurídica de direto } \\
\text { público; } \\
\text { b) Estabilidade legal e } \\
\text { constitucional; } \\
\text { c) A demissão é aceita sem } \\
\text { análise. }\end{array}$ & $\begin{array}{l}\text { A reintegração deve acontecer devido a falhas } \\
\text { no processo de demissão do indivíduo. A } \\
\text { fundação presta serviços públicos em saúde e } \\
\text { deve seguir tais diretrizes e } \\
\text { consequentemente respeitar a estabilidade } \\
\text { prevista na legislação vigente. Ou ainda, } \\
\text { quando ocorre o aceite do pedido de demissão } \\
\text { sem que o indivíduo tenha capacidade para } \\
\text { fazê-lo. }\end{array}$ \\
\hline $\begin{array}{l}\text { Sujeitos: 2, 5, 6, 10, 21, 22, 24, 25, 26, 28, 31, 32, 34, 35, 37, 41, 42, 44, 45, 47, 53, 54, 55, 56, 57, } \\
58,59,60,62,64,67,71,72,73,75,79,85,90 .\end{array}$
\end{tabular}


- DCS: responsabilidade objetiva

\begin{tabular}{|l|l|l|}
\hline Palavra-Chave & Ideias Centrais & Discurso do Sujeito Coletivo \\
\hline Responsabilidade & a) Dano acidentário & O nexo causal fica demonstrado pois o dano \\
& b) Nexo causal; & tem total relação com as atividades exercidas \\
& c) Doença profissional ou \\
ocupacional. & $\begin{array}{l}\text { pela reclamante. Independentemente de culpa } \\
\text { ou dolo a "a culpa empresarial" é caracterizada } \\
\text { pela responsabilidade objetiva da } \\
\text { empregadora nos danos acidentários, em face } \\
\end{array}$ \\
& do risco apresentado. \\
\hline
\end{tabular}

- DCS: responsabilidade subsidiária e/ou solidária

\begin{tabular}{|c|c|c|}
\hline Palavra-Chave & Ideias Centrais & Discurso do Sujeito Coletivo \\
\hline $\begin{array}{l}\text { Responsabilidade } \\
\text { subsidiária e/ou } \\
\text { solidária }\end{array}$ & $\begin{array}{l}\text { a) A primeira reclamada } \\
\text { deixou de cumprir as } \\
\text { obrigações contratuais; } \\
\text { b) Utiliza as dependências da } \\
\text { outra ré; } \\
\text { c) Obrigação de fiscalizar o } \\
\text { contrato. }\end{array}$ & $\begin{array}{l}\text { Os serviços foram prestados pela Fundação } \\
\text { nas dependências da Secretaria de Estado da } \\
\text { Saúde (Hospital Estadual Américo Brasiliense). } \\
\text { A terceirização tem como propósito reduzir } \\
\text { custos e suprimir direitos laborais. Ou seja, a } \\
\text { segunda é tomadora dos serviços da primeira e } \\
\text { deveria fiscalizar o cumprimento das } \\
\text { obrigações contratuais. A mesma situação } \\
\text { aplica-se quando a Fundação terceiriza } \\
\text { serviços, como: limpeza e segurança. }\end{array}$ \\
\hline \multicolumn{3}{|c|}{$\begin{array}{l}\text { Sujeitos: } 6,19,20,21,22,23,24,25,28,30,33,34,35,37,38,41,42,43,44,45,46,47,48,51 \text {, } \\
55,56,57,58,59,60,61,62,64,65,66,67,70,71,72,73,74,75,77,79,80 .\end{array}$} \\
\hline
\end{tabular}

d) monitorar pessoas

- DCS: indenização por danos morais por assédio moral

\begin{tabular}{|c|c|c|}
\hline Palavra-Chave & Ideias Centrais & Discurso do Sujeito Coletivo \\
\hline $\begin{array}{l}\text { Indenização por } \\
\text { danos morais por } \\
\text { assédio moral }\end{array}$ & $\begin{array}{l}\text { a) Psicoterrorismo por parte } \\
\text { da chefia } \\
\text { b) Constrangimento moral } \\
\text { c) Forçar o empregado a } \\
\text { pedir demissão }\end{array}$ & $\begin{array}{l}\text { Sofria com tratamentos desiguais e abuso na } \\
\text { utilização do poder por parte da chefia. } \\
\text { Trabalhava em um ambiente infectado com } \\
\text { atitudes agressivas emocionais, o que causou } \\
\text { grandes danos psicológicos e emocionais. }\end{array}$ \\
\hline
\end{tabular}




\begin{tabular}{|l|l|l|}
\hline & $\begin{array}{l}\text { Existia a cobrança excessiva, discriminação no } \\
\text { seu labor, controle da vida pessoal, tratamento } \\
\text { diferenciado, isolamento, etc. Aparentemente } \\
\text { o objetivo era forçar o empregado a pedir } \\
\text { demissão ante ao ambiente de labor }\end{array}$ \\
\hline Sujeitos: $17,35,38,41,45,46,47,50,54,57,59,71,73,80$. \\
\hline Processo da Gestão de Pessoas relacionado: monitorar pessoas \\
\hline
\end{tabular}

e) recompensar pessoas

- DCS: indenização por danos morais pela demora no agendamento da homologação ou dispensa

\begin{tabular}{|c|c|c|}
\hline Palavra-Chave & Ideias Centrais & Discurso do Sujeito Coletivo \\
\hline $\begin{array}{lr}\text { Indenização } & \text { por } \\
\text { danos morais pela } & \\
\text { demora } & \text { no } \\
\text { agendamento } & \text { da } \\
\text { homologação } & \text { ou } \\
\text { dispensa } & \end{array}$ & $\begin{array}{l}\text { a) Demora no agendamento } \\
\text { da homologação ou } \\
\text { dispensa } \\
\text { b) Indevidamente cerceado } \\
\text { de seu salário }\end{array}$ & $\begin{array}{l}\text { Tendo em vista o transtorno e a angústia pelo } \\
\text { período em que a Reclamante ficou sem } \\
\text { receber seu FGTS e habilitação no seguro } \\
\text { desemprego, pelo simples fato de a } \\
\text { Reclamada não agendar sua homologação da } \\
\text { Rescisão do Contrato de Trabalho. A conduta } \\
\text { de má-fé da empregadora, no intuito de trazer } \\
\text { prejuízos ao obreiro, que ficara indevidamente } \\
\text { cerceado de seu salário, por despedida } \\
\text { arbitrária, de modo a ferir a dignidade da } \\
\text { pessoa humana, em sintonia com julgados } \\
\text { laborais. }\end{array}$ \\
\hline
\end{tabular}

- DCS: indenização por lucros cessantes, reparação ou valores descontados

\begin{tabular}{|c|c|c|}
\hline Palavra-Chave & Ideias Centrais & Discurso do Sujeito Coletivo \\
\hline $\begin{array}{l}\text { Indenização por } \\
\text { lucros cessantes, } \\
\text { reparação ou } \\
\text { valores } \\
\text { descontados }\end{array}$ & $\begin{array}{l}\text { a) Afastamento por culpa da } \\
\text { reclamada; } \\
\text { b) Restituição de valores } \\
\text { indevidamente } \\
\text { descontados; } \\
\text { c) Despesa necessária. }\end{array}$ & $\begin{array}{l}\text { Ora, o afastamento, se deu por culpa da } \\
\text { Reclamada, o que impõe o pagamento de } \\
\text { indenização do período. É plenamente } \\
\text { possível o acúmulo do recebimento de } \\
\text { benefício previdenciário com indenização por } \\
\text { lucros cessantes, pois possuem diferentes } \\
\text { naturezas jurídicas. Além disso, a reclamada } \\
\text { descontou indevidamente supostas faltas que }\end{array}$ \\
\hline
\end{tabular}




\begin{tabular}{|l|l|l|}
\hline & $\begin{array}{l}\text { foram justificadas mediante atestados médicos } \\
\text { devidamente apresentados pela reclamada. } \\
\text { Ou ainda, não restituiu valores referente a } \\
\text { despesas (plano de saúde, cursos, etc.) dos } \\
\text { empregados. }\end{array}$ \\
\hline Sujeitos: $16,17,18,26,30,41,43,51,70,74,81,83$. \\
\hline Processo da Gestão de Pessoas relacionado: Recompensar pessoas \\
\hline
\end{tabular}

- DCS: nulidade da redução salarial

\begin{tabular}{|l|l|l|}
\hline Palavra-Chave & Ideias Centrais & Discurso do Sujeito Coletivo \\
\hline A construção do discurso foi descarta em razão da baixa representatividade. \\
\\
\hline Sujeitos: $16,56$. \\
\hline Processo da Gestão de Pessoas relacionado: Recompensar pessoas \\
\hline
\end{tabular}

- DCS: nulidade do banco de horas

\begin{tabular}{|l|l|l|}
\hline Palavra-Chave & Ideias Centrais & Discurso do Sujeito Coletivo \\
\hline $\begin{array}{l}\text { Nulidade do anco de horas } \\
\text { banco de horas } \\
\text { requisitos legais para } \\
\text { sistema de banco de } \\
\text { horas; } \\
\text { b) O pagamento dever ser } \\
\text { feito em forma de horas } \\
\text { extras. }\end{array}$ & $\begin{array}{l}\text { O pedido pela nulidade do banco } \\
\text { ocorre baseado que a compensação de horas } \\
\text { não poderá ser feita em período superior aos } \\
12 \text { meses e o acordo deve ter validade } \\
\text { somente quando celebrado com a assistência } \\
\text { do Sindicato. Por não atender tais requisitos o } \\
\text { pagamento deve ser feito em forma de horas } \\
\text { extras. }\end{array}$ \\
\hline $\begin{array}{l}\text { Sujeitos: 4, 40, 42, 44, 45, 46, 47, 48, 54, 55, 56, 57, 58, 59, 60, 61, 62, 64, 65, 66, 67, 71, 72, 73, } \\
77,82,84,90 .\end{array}$ \\
\hline \multicolumn{2}{|l|}{ Processo da Gestão de Pessoas relacionado: Recompensar pessoas } \\
\hline
\end{tabular}

- DCS: pagamento da dobra das férias

\begin{tabular}{|l|l|l|}
\hline Palavra-Chave & Ideias Centrais & Discurso do Sujeito Coletivo \\
\hline $\begin{array}{l}\text { Pagamento da } \\
\text { dobra das férias }\end{array}$ & $\begin{array}{c}\text { a) Férias concedidas após o } \\
\text { prazo legal; }\end{array}$ & $\begin{array}{l}\text { Assim, mais do que justo se faz o pagamento } \\
\text { em dobro dos valores relativos aos os períodos } \\
\text { de férias não gozados pela reclamante, por }\end{array}$ \\
\hline
\end{tabular}




\begin{tabular}{|l|l|}
\hline \multirow{1}{*}{} & $\begin{array}{l}\text { todo o período contratual não prescrito, } \\
\text { inclusive com inclusão na média salarial dos } \\
\text { valores referentes às horas extras habituais, } \\
\text { adicional de insalubridade, bem como no } \\
\text { adicional de } 1 / 3 \text { de férias, por força dos artigos } \\
134,137 \text { e } 142, \S 5^{\circ} \text { da } C L T \text {, bem como todos } \\
\text { os recolhimentos reflexos (INSS, FGTS), com } \\
\text { fulcro no art. } 138 \text { da CLT. }\end{array}$ \\
\hline Sujeitos: $56,60,65,70,71,72,84,87,90$.
\end{tabular}

- DCS: pagamento de adicional de sobreaviso

\begin{tabular}{|l|l|l|}
\hline Palavra-Chave & Ideias Centrais & Discurso do Sujeito Coletivo \\
\hline A construção do discurso foi descarta em razão da baixa representatividade. \\
\\
\hline Sujeitos: $8,22,24$. \\
\hline Processo da Gestão de Pessoas relacionado: Recompensar pessoas \\
\hline
\end{tabular}

- DCS: pagamento de benefícios

\begin{tabular}{|l|l|l|}
\hline Palavra-Chave & Ideias Centrais & Discurso do Sujeito Coletivo \\
\hline A construção do discurso foi descarta em razão da baixa representatividade. \\
\hline Sujeitos: 43 \\
\hline Processo da Gestão de Pessoas relacionado: Recompensar pessoas \\
\hline
\end{tabular}

- DCS: pagamento de diferenças nas verbas contratuais ou rescisórias

\begin{tabular}{|l|l|l|}
\hline Palavra-Chave & \multicolumn{1}{|c|}{ Ideias Centrais } & \multicolumn{1}{c|}{ Discurso do Sujeito Coletivo } \\
\hline Pagamento de & a) & Incorporação da \\
diferenças nas & "gratificação local" e & Requer os reflexos nas verbas contratuais e/ou \\
verbas & & $\begin{array}{l}\text { rescisórias pela habitualidade de ocorrências, } \\
\text { como: horas extras, desvio de função, }\end{array}$ \\
\hline
\end{tabular}




\begin{tabular}{|c|c|c|c|}
\hline $\begin{array}{l}\text { contratuais ou } \\
\text { rescisórias }\end{array}$ & b) & $\begin{array}{l}\text { “insalubridade" na base } \\
\text { de cálculo; } \\
\text { Condenação pela } \\
\text { habitualidade de rotinas; } \\
\text { Diferença ou saldo de } \\
\text { valor remanescente para } \\
\text { pagamento. }\end{array}$ & $\begin{array}{l}\text { supressão de intervalo, trabalho noturno, etc. } \\
\text { Desde o início do contrato com a reclamada, } \\
\text { sempre foram pagas as gratificações local e } \\
\text { adicional de insalubridade, devendo servir de } \\
\text { base para todos os cálculos. Assim sendo, } \\
\text { requerer que a reclamada seja condenada ao } \\
\text { pagamento das diferenças salariais, bem como } \\
\text { que seja feito o pagamento das diferenças dos } \\
\text { salários nas horas extras, férias }+1 / 3,13^{\circ} \text { salário } \\
\text { e FGTS, de todo o período de trabalho. }\end{array}$ \\
\hline
\end{tabular}

Sujeitos: $2,3,4,7,8,9,10,11,12,13,14,15,16,18,19,20,21,22,3,24,26,28,29,31,32,33$, $34,35,37,38,39,40,41,42,43,44,45,46,47,48,51,54,55,56,57,58,59,60,61,62,63,64$, $65,66,67,68,69,70,71,72,73,74,76,77,79,80,81,82,83,84,86,87,88,89,90$.

Processo da Gestão de Pessoas relacionado: Recompensar pessoas

- DCS: pagamento de folgas e feriados trabalhados

\begin{tabular}{|l|l|l|}
\hline Palavra-Chave & Ideias Centrais & Discurso do Sujeito Coletivo \\
\hline $\begin{array}{l}\text { Pagamento de } \\
\text { folgas e feriados } \\
\text { trabalhados }\end{array}$ & $\begin{array}{l}\text { a) Não havia possiblidade de } \\
\text { descanso; } \\
\text { b) Sempre ocorre o trabalho } \\
\text { em feriados; } \\
\text { c) Permanece a disposição } \\
\text { da empresa. }\end{array}$ & $\begin{array}{l}\text { O pedido de pagamento em dobro dá-se do } \\
\text { labor constante em feriados nacionais, } \\
\text { religiosos, estaduais e municipais de maneira } \\
\text { que não acontecia o pagamento dos dias como } \\
\text { horas extras, banco de horas ou ainda } \\
\text { qualquer compensação pelo trabalho } \\
\text { realizado. Isso faz com que o trabalhador } \\
\text { permaneça sempre à disposição do } \\
\text { empregador. }\end{array}$ \\
& & \\
&
\end{tabular}

Sujeitos: $33,40,42,43,44,45,46,54,55,56,57,58,59,60,61,62,63,64,65,66,67,70,71,72$, 73, 76, 77, 82, 84, 88, 89.

Processo da Gestão de Pessoas relacionado: Recompensar pessoas

- DCS: pagamento de horas extras

\begin{tabular}{|c|c|c|}
\hline Palavra-Chave & Ideias Centrais & Discurso do Sujeito Coletivo \\
\hline $\begin{array}{l}\text { Pagamento de } \\
\text { horas extras }\end{array}$ & $\begin{array}{l}\text { a) Habitualidade das horas } \\
\text { extras; } \\
\text { b) Falta de acesso para } \\
\text { conferência do banco de } \\
\text { horas; } \\
\text { c) Negava a concessão de } \\
\text { folgas; }\end{array}$ & $\begin{array}{l}\text { A Reclamante durante todo o seu contrato de } \\
\text { trabalho foi obrigada a laborar e por diversas } \\
\text { vezes extrapolava a jornada de trabalho, e } \\
\text { consequentemente fazia horas extras. As } \\
\text { referidas horas extras eram lançadas em } \\
\text { banco de horas, porém o mesmo não era } \\
\text { acessível. A compensação era concedida }\end{array}$ \\
\hline
\end{tabular}




\begin{tabular}{|c|c|}
\hline & $\begin{array}{l}\text { apensa em períodos que a autora não tinha } \\
\text { interesse ou lhe prejudicasse. }\end{array}$ \\
\hline $\begin{array}{l}\text { Sujeitos: } 4,7,8,1 \\
48,55,56,57,59\end{array}$ & $\begin{array}{l}24,28,31,34,38,0,41,42,43,44,45,6,47 \\
72,73,74,76,77,80,82,84,87,88,89,90 .\end{array}$ \\
\hline
\end{tabular}

- DCS: pagamento de multas

\begin{tabular}{|c|c|c|}
\hline Palavra-Chave & Ideias Centrais & Discurso do Sujeito Coletivo \\
\hline $\begin{array}{l}\text { Pagamento de } \\
\text { multas }\end{array}$ & $\begin{array}{l}\text { a) Não respeitar o prazo de } \\
\text { pagamento das verbas } \\
\text { rescisórias; } \\
\text { b) Controvérsia no valor das } \\
\text { verbas rescisórias; } \\
\text { c) Efetuar o pagamento na } \\
\text { primeira audiência }\end{array}$ & $\begin{array}{l}\text { O pedido da multa ocorre pela demora na } \\
\text { homologação da rescisão, a qual veio ocorrer } \\
\text { meses após o termino do contrato, é quando } \\
\text { se aplica a multa do art. } 477 \text { da CLT. É } \\
\text { incontroverso quando ocorre a diferença no } \\
\text { pagamento de verbas, como: adicional } \\
\text { noturno, trabalho em feriados, concessão de } \\
\text { descanso semanal, intervalo intrajornada, e } \\
\text { normas coletivas. Sendo que o pagamento } \\
\text { dessa diferença deve ser efetuado na primeira } \\
\text { audiência sob pena de aplicação de multa } \\
\text { prevista no art. } 467 \text { da CLT. }\end{array}$ \\
\hline \multicolumn{3}{|c|}{$\begin{array}{l}\text { Sujeitos: } 2,7,8,19,20,21,22,23,24,29,30,31,33,34,35,37,39,40,41,42,43,44,45,47,48 \text {, } \\
51,55,57,58,59,60,61,62,64,65,70,72,73,74,75,85 .\end{array}$} \\
\hline
\end{tabular}

- DCS: pagamento do adicional de insalubridade

\begin{tabular}{|l|l|l|}
\hline Palavra-Chave & Ideias Centrais & Discurso do Sujeito Coletivo \\
\hline $\begin{array}{l}\text { Pagamento do dicional } \\
\text { insalubridade de }\end{array}$ & $\begin{array}{r}\text { a) Não ocorria o pagamento } \\
\text { correto da insalubridade; } \\
\text { b) Pagar de acordo com as } \\
\text { Convenções Coletivas } \\
\text { c) É utilizado um grau de } \\
\text { risco menor no cálculo. }\end{array}$ & $\begin{array}{l}\text { Ocorria o contato direto com situaçes insalubres e ainda ocorria falha no } \\
\text { locais } \\
\text { fornecimento de determinados EPl's. Os } \\
\text { valores fixos estipulados para pagamento da } \\
\text { insalubridade constavam nas Convenções } \\
\text { Coletivas, porém os valores eram pagos de } \\
\text { outra forma ou ainda pagos como um grau de } \\
\text { risco menor. }\end{array}$ \\
\hline $\begin{array}{l}\text { Sujeitos: 3, 8, 13, 14, 15, 16, 18, 29, 31, 33, 35, 38, 41, 42, 43, 46, 47, 48, 53, 63, 69, 74, 82, 86, } \\
87,88,89,90 .\end{array}$ \\
\hline
\end{tabular}


- DCS: pagamento do adicional de periculosidade

\begin{tabular}{|l|l|l|}
\hline Palavra-Chave & Ideias Centrais & Discurso do Sujeito Coletivo \\
\hline $\begin{array}{l}\text { Pagamento do } \\
\text { adicional de }\end{array}$ & $\begin{array}{l}\text { a) Erro no pagamento do } \\
\text { vericulosidade da periculosidade. }\end{array}$ & $\begin{array}{l}\text { Desde o início do contrato de trabalho a } \\
\text { primeira reclamada pagou valor inferior ao } \\
\text { percentual determinado por lei e constante da } \\
\text { CCT. }\end{array}$ \\
\hline \multicolumn{2}{|l|}{ Sujeitos: 11, 30, 33, 40, 51, 70. } \\
\hline \multicolumn{2}{|l|}{ Processo da Gestão de Pessoas relacionado: Recompensar pessoas } \\
\hline
\end{tabular}

- DCS: pagamento do adicional noturno

\begin{tabular}{|l|l|l|}
\hline Palavra-Chave & Ideias Centrais & Discurso do Sujeito Coletivo \\
\hline Pagamento do & $\begin{array}{l}\text { a) Erro no pagamento do } \\
\text { valor do adicional noturno. }\end{array}$ & $\begin{array}{l}\text { Embora a Reclamante laborasse no período } \\
\text { noturno, a Reclamada não efetuava o } \\
\text { pagamento do adicional noturno de forma } \\
\text { correta, pois os lançamentos no contracheque } \\
\text { sempre continham o pagamento inferior ao } \\
\text { devido. Ocorre que embora o Reclamante } \\
\text { laborasse durante todo o período noturno, a } \\
\text { empresa ré apenas efetuava o pagamento do } \\
\text { adicional noturno até as 05 horas. }\end{array}$ \\
\hline Sujeitos: 7, 8, 11, 12, 28, 33, 34, 40, 42, 44, 45, 46, 54, 55, 56, 58, 66, 71, 72, 73, 74, 76, 77. \\
\hline Processo da Gestão de Pessoas relacionado: Recompensar pessoas \\
\hline
\end{tabular}

f) categorias descartadas

As categorias com ideias centrais com conteúdo divergente dos processos da GP foram descartadas: "tutela de urgência", "intimação da parte adversa", "juntada de documentos", "prioridade na tramitação, tutela de urgência ou antecipada" "encaminhamento para apuração a outros órgãos públicos", "juros e correção monetária", "honorários advocatícios sucumbenciais", "justiça gratuita", "expedir notificações em nome do advogado". 
9 ANEXOS 


\title{
ANEXO A - TERMO DE CONSENTIMENTO LIVRE E ESCLARECIDO
}

\author{
UNIVERSIDADE DE SÃO PAULO
}

FACULDADE DE MEDICINA DE RIBEIRÃO PRETO

Solicitação de isenção do termo de consentimento livre e esclarecido ao Comitê de Ética em Pesquisa:

Referência: Avaliação da estratégia de gestão de pessoas frente à caracterização dos pedidos de reclamação trabalhista de uma organização social

Pesquisador: Leandro Ultramari

Vimos por meio deste documento solicitar a dispensa de obtenção de um Termo de Consentimento Livre e Esclarecido (TCLE) para o estudo intitulado "AVALIAÇÃO DA ESTRATÉGIA DE GESTÃO DE PESSOAS FRENTE À CARACTERIZAÇÃO DOS PEDIDOS DE RECLAMAÇÃO TRABALHISTA DE UMA ORGANIZAÇÃO SOCIAL", proposto por Leandro Ultramari.

A dispensa do uso de TCLE se fundamenta: a) por ser um estudo observacional, analítico, descritivo retrospectivo, que empregará apenas informaçōes de petições inicais de ações trabalhistas, sistemas de informação institucionais e/ou demais fontes de dados e informações disponiveis na instituiçăo; b) porque todos os dados serão manejados e analisados de forma anônima, sem identificação nominal dos participantes de pesquisa; c) porque os resultados decorrentes do estudo serão apresentados de forma agregada, não permitindo a identificação individual dos participantes, e d) porque se trata de um estudo não intervencionista (sem intervenções clínicas) e sem alteraçôes/influências na rotina/tratamento do participante de pesquisa, e consequentemente sem adição de riscos ou prejuízos ao bemestar dos mesmos.

$\mathrm{O}$ investigador principal e demais colaboradores envolvidos no estudo acima se comprometem, individual e coletivamente, a utilizar os dados provenientes deste, apenas para os fins descritos e a cumprir todas as diretrizes e normas regulamentadoras descritas na Res. $\mathrm{CNS} \mathrm{N}^{\circ} 466 / 12$, e suas complementares, no que diz respeito ao sigilo e confidencialidade dos dados coletados.

Ribeirão Preto, 03 de de 2018.

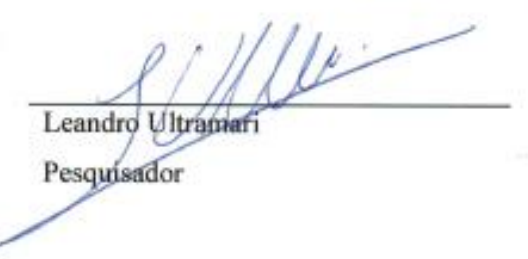
Prof. Dr. Tales Rubens de Nadai Orientador 


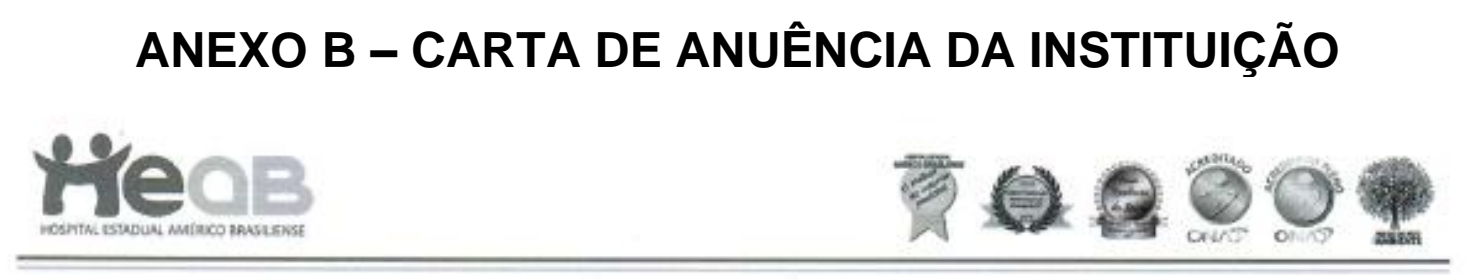

\section{CARTA DE ANUÊNCIA}

Declaro, para os devidos fins que eu, Mário Sérgio Bezerra de Menezes, colaborador do Hospital Estadual Américo Brasiliense, atuante na função de Diretor Administrativo, reconheço a importância e relevância do projeto de pesquisa "AVALIAÇÃO DA ESTRATÉGIA DE GESTÃO DE PESSOAS FRENTE A CARACTERIZAÇÃO DOS PEDIDOS DE RECLAMAÇÃO TRABALHISTA DE UMA ORGANIZAÇÃO SOCIAL", o qual será desenvolvido pelo pesquisador Leandro Ultramari, sob orientaçăo do Prof. Dr. Tales Rubens de Nadai.

Sendo assim, defiro a realização deste estudo no Hospital Estadual Américo Brasiliense. Lembro que as formas de citação desta instituição nas publicaçőes nacionais e internacionais são: Hospital Estadual Américo Brasiliense e/ou Americo Brasiliense State Hospital.

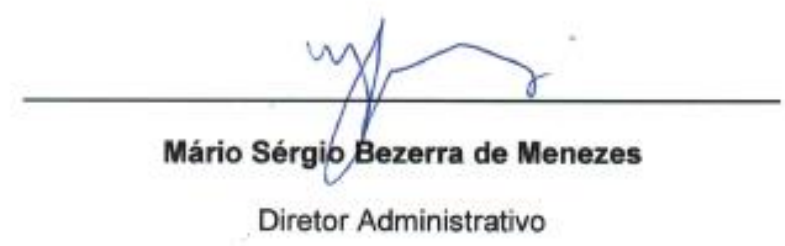

Hospital Estadual Américo Brasiliense 


\section{ANEXO C - APROVAÇÃO DO COMITÊ DE ÉTICA}

\section{DADOS DA VERSÃO DO PROJETO DE PESQUISA}

Título da Pesquisa: AVALIAÇÃO DA ESTRATÉGIA DE GESTÃO DE PESSOAS FRENTE À CARACTERIZAÇÃO DOS PEDIDOS DE RECLAMAÇÃO TRABALHISTA DE UMA ORGANIZAÇÃO SOCIAL

Pesquisador Responsável: Tales Rubens de Nadai

Versão: 1

CAAE: 90539018.7 .0000 .5414

Submetido em: 23/05/2018

Instituição Proponente: SAO PAULO SECRETARIA DA SAUDE

Situação da Versão do Projeto: Aprovado

Localização atual da Versão do Projeto: Pesquisador Responsável

Patrocinador Principal: Financiamento Próprio

Recomendações:

Nenhuma recomendação.

Sou de parecer favorável à dispensa do TCLE e à aprovação do projeto pelo CEP.

Conclusões ou Pendências e Lista de Inadequações:

Nenhuma pendência.

Considerações Finais a critério do CEP:

Acatado o parecer do relator de aprovar o projeto.

Situação do Parecer:

Aprovado

Necessita Apreciação da CONEP:

Não

RIBEIRAO PRETO, 07 de agosto de 2018. Assinado por LAÉRCIO JOEL FRANCO (Coordenador). 